TRANSCENDING SOVEREIGNTY:

\title{
LOCATING INDIGENOUS PEOPLES IN TRANSBOUNDARY WATER LAW
}

by

JENNIFER LYNNE ARCHER

LL.B., University of British Columbia, 1996

B.A., University of Alberta, 1993

\section{A THESIS SUBMITTED IN PARTIAL FULFILLMENT OF} THE REQUIREMENTS FOR THE DEGREE OF

\section{MASTER OF LAWS}

in

THE FACULTY OF GRADUATE STUDIES

THE UNIVERSITY OF BRITISH COLUMBIA

(Vancouver)

January 2012

(C) Jennifer Lynne Archer, 2012 


\begin{abstract}
All people rely upon water for life. Indigenous peoples are especially vulnerable to water conflicts and yet lack recognition in international water law. This thesis adopts Critical Race Theory to examine the intersection between transboundary water law, the doctrine of sovereignty and the international law of Indigenous peoples. The methodology adopted in this thesis includes: (i) a deconstruction of the UN Watercourse Convention and the doctrine of sovereignty; (ii) a review of Indigenous perspectives on sovereignty; and (iii) a proposal for the reconstruction of transboundary water law in a manner that recognizes the internationally affirmed rights of Indigenous peoples.
\end{abstract}

A deconstruction of the UN Watercourse Convention and related discourse reveals that state-centric approaches to transboundary water law fail to recognize Indigenous peoples' international rights or the pivotal role that Indigenous peoples' traditional knowledge might play in transcending conflict. Case examples are provided (Columbia River and Tsangpo-Brahmaputra River) that illustrate the vulnerability of Indigenous peoples in the face of state development agreements. The inequities that exist in international water law are rooted in the historical doctrine of sovereignty which has evolved to subordinate Indigenous peoples' interests to state interests.

Indigenous perspectives regarding sovereignty provide a counter-point to the dominant legal discourse and weave an alternate narrative that challenges the myth of objectivity and neutrality that surrounds the doctrine of sovereignty and international law generally. Once we recognize that sovereignty is a social construct, we can recognize our collective ability to reconstruct international laws in a manner that transcends the sovereign discourse and recognizes the rights of Indigenous peoples. Endorsement of the United Nations Declaration on the Rights of Indigenous Peoples (UNDRIP) is indicative of states' commitment to recognize Indigenous peoples' rights throughout the international legal system.

This thesis concludes by offering a proposal for reconstructing transboundary water law through a return to ethics and coalition building. Future reform should be directed towards (a) articulating an international water ethic with the critical engagement of Indigenous peoples; and (b) ensuring that river basin organizations are established on every transboundary river in a manner consistent with this shared international water ethic. 


\section{Table of Contents}

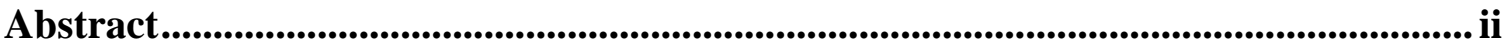

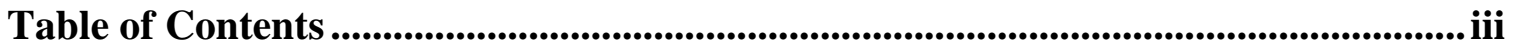

List of Figures................................................................................................................................ iv

Acknowledgements .................................................................................................................................... v v

Dedication .................................................................................................................................. vii

Chapter 1: Introduction............................................................................................. 1

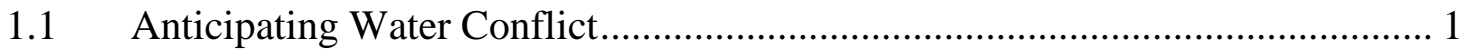

1.2 Transboundary Water Law, Indigenous Peoples and Sovereignty .................... 3

1.3 Theoretical Framework and Methodology...................................................... 11

1.4 Deconstructing My Settler Self: On Becoming an Ally in Water Law ............ 17

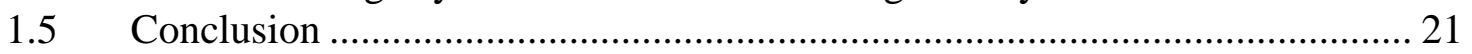

Chapter 2: International Water Law: A Deconstruction ...................................... 22

2.1 International Water Law and the Doctrine of Sovereignty ........................... 23

2.2 Locating Indigenous Peoples in International Water Law ............................... 37

2.3 Case Studies: Indigenous Peoples' Interests in Two Transboundary Rivers.... 46

2.4. Conclusions: The Problem With Sovereignty............................................ 75

Chapter 3: Sovereignty as a Social Construct: Indigenous Perspectives .............. 82

3.1 Providing Context: Sovereignty in Western Traditions ................................... 84

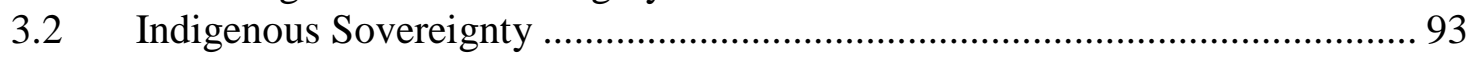

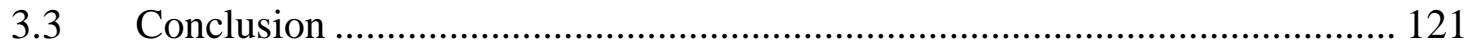

Chapter 4: Transcending Sovereignty: Reconstructing the International Law of

Transboundary Rivers.............................................................................................. 125

4.1 Asserting International Indigenous Rights: Methodology for Reform ......... 127

4.2 Recognizing International Indigenous Rights: Precedents for Reform ......... 137

4.3 Implications for International Water Law: Proposals for Reconstruction ...... 148

4.4 River Basin Organizations as "Ethical Spaces" ........................................... 158

4.5 Conclusion ..................................................................................... 166

Chapter 5: Conclusion: A Return to Ethics ..................................................... 172

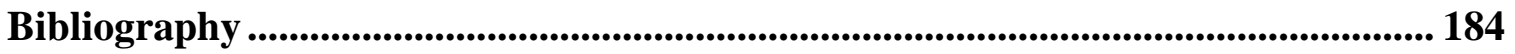

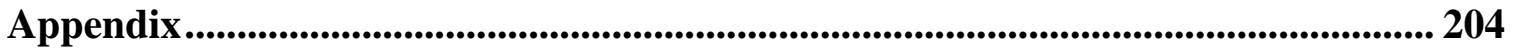

Appendix A: Indigenous Water Declarations \& Recommendations ...................... 204 


\section{List of Figures}

Figure 2.1: Map of the Columbia River Basin. ................................ 182

Figure 2.2: Map of Tsangpo-Brahmaputra Basin...............................183 


\section{Acknowledgements}

I have been supported and guided by many people on this journey.

I extend my gratitude to my supervisor, Professor June McCue, for writing the article that inspired me to undertake this project, for providing invaluable advice throughout the drafting process and for always speaking to me in a way that my heart understands.

I am also grateful to Professor Benjamin Richardson for his role as second reader on my committee.

My thesis has benefited from the guidance of many UBC Professors, who provided invaluable comments that helped me develop my thesis in its early stages. I especially wish to extend my appreciation to Professors Natasha Affolder, Richard Paisley, Karen Bakker and Wesley Pue. I am also grateful for the unwavering support of Professor Douglas Harris, Associate Dean Graduate Studies \& Research, Faculty of Law and Joanne Chung, Graduate Program Advisor, Faculty of Law.

My thesis also benefited greatly from my conversations with fellow students who inspired me in their commitment to social justice. In particular, I wish to extend my appreciation to Lynda Collins, Pooja Parmar, Derek Christ and special thanks to Tashi Tsering, who was the first to introduce me to the beauty and wonder of the Yarlung Tsangpo River.

I am grateful for the many conversations that I have shared with my mentor and friend, D. Anthony Knox, who challenges me to think deeply about the meaning and process of reconciliation. I also am grateful to Kindy Gosal, Director, Water \& Environment, Columbia Basin Trust, who allowed me to participate in formative meetings of the Canadian Columbia Basin Forum and who inspired me in his commitment to grassroots initiatives within the Columbia River Basin. 
Finally, I have been blessed with tremendous support and encouragement from my extended family. I especially wish to thank:

Sandy Umpleby, my mother, coach, mentor and role model - who read every word and whose faith in me gave me the momentum to see this through.

My father, Dennis Umpleby, for his unwavering commitment to integrity in all matters, which has become the foundation for my own life and work.

My brothers, Loki and James, for always challenging me to think critically and act creatively.

My sister, Jane Henderson, for feeding my family and nourishing my heart. Your gifts are immense.

My sons, Gavin \& Fraser, for helping me to keep everything in perspective.

Finally, I wish to extend my enduring and heartfelt gratitude to my partner, Viv, for never having any doubt. He has made this whole endeavour possible.

Without deviation from the norm, progress is not possible. Frank Zappa 
This thesis is lovingly dedicated to my mother, Sandra L. Umpleby, Ph.D. Her encouragement and constant love have sustained me throughout.

Love is a river. Drink from it. $\sim$ Rumi 


\section{Chapter 1: Introduction}

Water is life's mater and matrix, mother and medium. There is no life without water. ${ }^{l}$

Albert Szent-Gyorgyi

Fierce national competition over water resources has prompted fears that water issues contain the seeds of violent conflict. If all the world's peoples work together, a secure and sustainable water future can be ours. ${ }^{2}$

\section{Kofi Annan, former UN Secretary General}

\subsection{Anticipating Water Conflict}

Water is the world's most precious resource. Water is life. All living beings depend upon water for survival. As a growing global population relies upon dwindling supplies of fresh potable water, conflict over how water is governed appears inevitable. However, there is also an unprecedented opportunity for cooperation and reconciliation as we come to terms with our interdependence and the fragility of our existence on this planet. ${ }^{3}$ Given the paramount importance of water to our survival and the inevitability of conflict over limited water resources, thoughtful governance strategies are required to guide ethical human relationships regarding shared water. The need for effective international water laws is especially pressing within the context of transboundary rivers: rivers that flow through two or more sovereign states.

\footnotetext{
${ }^{1}$ Albert Szent-Gyorgyi, Biochemist, Nobel Prize Winner, cited in Saskatchewan Watershed Authority, "Celebrating and Conserving Water", online: Saskatchewan Watershed Authority <http://www.swa.ca/WaterConservation/default.asp?type=CelebratingWater $>$.

${ }^{2}$ Kofi Annan, former UN Secretary General, cited in UN-Water, Transboundary Waters" UN International Decade of Action, Water for Life 2005-2015, online: UN <http://www.un.org/waterforlifedecade/transboundary waters.shtml> [UN-Water].

3 Jeremy Rifkin, The Empathic Civilization: The Race to Global Consciousness in a World in Crisis (Penguin Group: New York, 2009).
} 
By their very nature, transboundary watercourses offer the potential to become flashpoints for conflict or cooperation. ${ }^{4}$ International river basins are not constrained by political boundaries and as such are potent reminders of the interconnectedness of our global ecosystem as well as the inherent limitations of sovereignty as an organizing principle of international water law. ${ }^{5}$ States and local communities can either compete for limited resources or work together to optimize use. There are approximately 260 transboundary river basins that cover $45 \%$ of the land surface of our planet. ${ }^{6}$ At least 145 nations have territory within an international drainage basin. ${ }^{7}$ Transboundary river basins currently support nearly half our global population and yet the availability of fresh water is declining rapidly. ${ }^{8}$ Brown \& Odeh observe that population growth alone over the last 100 years has led to an almost " 80 percent drop in per capita water availability". 9 Increasingly, stress on the natural environment due to water scarcity, pollution, resource development and climate change have magnified the growing need for facilitated

\footnotetext{
${ }^{4}$ Heather L Beach et al. Transboundary freshwater dispute resolution: Theory, practice and annotated references (New York: United Nations University Press, 2000) at 39 [Beach et al].

${ }^{5}$ Stephen C McCaffrey, The Law of International Watercourses, $2^{\text {nd }}$ ed (Oxford: Oxford University Press, 2007) at 68 [McCaffrey (2007)].

${ }^{6}$ Alex Grzybowski, Stephen C McCaffrey \& Richard K Paisley, "Beyond International Water Law: Successfully Negotiating Mutual Gains Agreements for International Watercourses" (2010) 22 Global Bus \& Dev't LJ 139 at 139-140 [Grzybowski et al].

${ }^{7}$ R Paisley \& G Hearns, "Some Observations from Recent Experiences with the Governance of International Drainage Basins" in AC Corréa and Gabriel Eckstein, eds, Precious, Worthless or Immeasurable: the Value and Ethics of Water, (Lubbock, Texas: Texas Tech University, 2006) online: Governance-IWLearn <http://governance-iwlearn.org/wp-content/uploads/2010/09/Texas-Tech.pdf > 1 at 4 [Paisley \& Hearns]. The authors define an "international drainage basin" as referring to "fresh water resources that are shared by two or more sovereign states". Thorson defines an "international drainage basin" as "more than simply a transboundary river, it is the entire geographic area of a watershed." See Erica J Thorson, "Sharing Himalayan Glacial Meltwater: The Role of Territorial Sovereignty" (2009) 19 Duke J Comp \& Int'l L 487, online: Duke University School of Law $<$ http://www.law.duke.edu/shell/cite.pl?19+Duke+J.+Comp.+\&+Int'l+L.+487+pdf $>$ at 506 [Thorson]. ${ }^{8}$ Paisley \& Hearns, ibid at 4.

${ }^{9}$ Anna Brown \& Nancy Odeh, "Towards a Global Transboundary Watercourse and Aquifer Agreement (GTWAA) in William R. Moomaw \& Lawrence E. Susskind, eds, Papers on International Environmental Negotiation, Volume 15 Ensuring a Sustainable Future (Boston: MIT-Harvard Public Disputes Program, 2006) online: Program on Negotiation, Harvard Law School <http://www.pon.harvard.edu/shop/papers-oninternational-environmental-negotiation-series/> 1 at 2 [Brown \& Odeh].
} 
transboundary cooperation and dispute resolution. The potential for conflict is immense; the opportunity and need for peace building around transboundary rivers is equally great. This thesis considers the international law of transboundary rivers from the perspective of Indigenous peoples who rely upon these resources for their survival and whose sacred responsibilities to water are central to their culture. ${ }^{10}$

\subsection{Transboundary Water Law, Indigenous Peoples and Sovereignty}

My thesis has evolved over time. I initially approached international water law from the question of how to increase public participation in the governance of transboundary rivers. However, early in my studies, I was given the opportunity to attend several formative meetings of the Canadian Columbia River Basin Forum comprised of dozens of federal and provincial department bureaucrats as well as representatives from

\footnotetext{
${ }^{10}$ Throughout this paper, I have used the word "Indigenous" in the spirit of the sentiments of preeminent international legal scholar, S James Anaya:

... the term indigenous refers broadly to the living descendants of preinvasion inhabitants of lands now dominated by others. ... They are indigenous because their ancestral roots are embedded in the lands in which they live, or would like to live, much more deeply than the roots of more powerful sectors of society living on the same lands or in close proximity. Furthermore, they are peoples to the extent they comprise distinct communities with a continuity of existence and identity that links them to the communities, tribes, or nations of their ancestral past.

See James S Anaya, Indigenous Peoples in International Law, $2^{\text {nd }}$ ed (Oxford: Oxford University Press, 2004) at 3 [Anaya (2004)]. Corntassel \& Primeau note that "indigenous" is the designation that "is most widely used among native populations themselves, by intergovernmental organizations (IGOs) such as the United Nations, as well as by many nongovernmental organizations (NGOs). See Jeff J Corntassel \& Tomas Hopkins Primeau, "Indigenous 'Sovereignty' and International Law: Revised Strategies for Pursuing Self-Determination" (1995) 17:2 Hum Rts Q as reprinted in (2006) 2 Hawaiian Journal of Law \& Politics 53 at 55 [Corntassel \& Primeau]. However, I also acknowledge that any definition of Indigenous may include inherent limitations. The UN Office of the High Commissioner of Human Rights affirms, "no formal universal definition is necessary for the recognition and protection of their rights". See UN Development Group, Guidelines on Indigenous Peoples' Issues, (2008) online: Office of the High Commissioner of Human Rights <http://www2.ohchr.org/english/issues/indigenous/docs/guidelines.pdf $>$ at 8. Other scholars expressly reject the term "aboriginal" and the term "Indian". See Taiaiake Alfred \& Jeff Corntassel, "Being Indigenous: Resurgences against Contemporary Colonialsm" (2005) 40:4 Government and Opposition 597 [Alfred \& Corntassel]; Akwesasne Notes, "Indigenous Peoples, Self-Determination and the Unfounded Fear of Secession" (1995) as reprinted in Robert Odawi Porter, ed, Sovereignty, Colonialism and the Indigenous Nations: A Reader (Durham, North Carolina: California Academic Press, 2005) 713 [Akwesasne Notes] [RO Porter]. I have adopted the term "Indigenous" throughout this paper except when quoting scholars that have used different terminology. Within the Canadian context, however, I have used the term "First Nations" where appropriate to indicate the Indigenous peoples that reside within Canada. The term "First Nations" does not include Métis or Inuit.
} 
several First Nations Bands that reside within the Canadian Columbia Basin. ${ }^{11}$ The experience was a transformative one for me personally. One observation in particular has had a lasting and profound impact upon my research. The communication gulf between government officials and the Indigenous representatives was staggering.

When the Indigenous representatives spoke about the pressing issues confronting the Columbia River, they spoke passionately of spirit, salmon and grandchildren. They called for a basin-wide approach to governance and emphasized the interconnectedness of all living things within the river basin. The bureaucrats smiled politely and spoke pragmatically of limited mandates, budget constraints, and overlapping political jurisdictions while simultaneously strategizing towards potential press releases. The gulf in understanding and intentions was palpable. At the core of the disconnection was a conflict of core values and different assumptions about the nature of our relationship with the river and its ecosystem. The Indigenous representatives stopped coming to the meetings. ${ }^{12}$ I became uncomfortable participating in the discussions between government departments and disengaged from the process.

Upon reflection, it became clear to me that the first step on the long road to participatory decision-making must begin by bridging the communication gap between the state governments and Indigenous peoples, and ensuring that the latter are truly

\footnotetext{
${ }^{11}$ Participants in these meetings included representatives from the following: British Columbia (BC) Ministry of Environment BC Hydro, BC Crown Agencies Secretariat, BC Intergovernmental Relations Office, BC Ministry of Energy, Mines \& Petroleum Resources, Canadian Columbia River Inter-tribal Fisheries Commission, Canadian Consulate - Seattle (DFAIT), Canadian Ministry of Indian \& Northern Affairs, Columbia Basin Trust, Environment Canada, Fisheries \& Oceans Canada, Natural Resources Canada, Okanagan Nation Alliance, Shuswap Nation Tribal Council, \& Ktunaxa Nation Council.

${ }^{12}$ First Nations did participate in subsequent meetings. In 2007, seventeen Canadian federal, provincial, regional and First Nation agencies signed a Memorandum of Understanding and have committed to collaborating on transboundary water management issues through the Canadian Columbia River Forum. See Canadian Columbia River Forum. "Canadian Columbia River Forum Memorandum of Understanding”, online: Canadian Columbia River Forum, <http://www.ccrf.ca/assets/docs/pdf/MOU_Eng_17.pdf>.
} 
engaged in the governance of transboundary rivers. I began to research the rights of Indigenous peoples in transboundary water law and found that, because they lacked recognition of power akin to sovereign status, they were excluded from the discourse on the law of transboundary rivers. Indigenous interests were summarily relegated to a matter of domestic concern, a common state practice of colonization. This struck me as contrary to the international status of Indigenous peoples as affirmed by the United Nations Declaration on the Rights of Indigenous Peoples [UNDRIP or the Declaration]. ${ }^{13}$

In 2010, UN Secretary-General Ban Ki-moon stated that one of the five objectives of the

Second International Decade of the World's Indigenous Peoples is:

Promoting the full and effective participation of indigenous peoples in decisions which directly or indirectly affect their lifestyles, their traditional lands and territories, their cultural integrity as indigenous peoples with collective rights or any other aspect of their lives... $\cdots$

... participation in intergovernmental work is a core element ... of the Second Decade and a fundamental human rights norm in international law, firmly enshrined in international human rights instruments. The United Nations Declaration on the Rights of Indigenous Peoples reconfirms this norm and analyses of its meaning as it pertains to indigenous peoples. ${ }^{14}$

\footnotetext{
${ }^{13}$ United Nations Declaration on the Rights of Indigenous Peoples, UN GAOR Doc.A/RES/61/295 (13 September 2007) online: UN <http://www.un.org/esa/socdev/unpfii/en/declaration.html> [UNDRIP].

${ }^{14}$ Ban Ki-moon, UN Secretary-General (2010), Report on the Midterm assessment of the progress made in the achievement of the goal and objectives of the Second International Decade of the World's Indigenous People, cited in Ellen Gabriel (Speaker), "Joint Statement of Grand Council of the Crees (Eeyou Istchee); Inuit Circumpolar Council; Assembly of First Nations: International Alliance of Indigenous and Tribal Peoples of Tropical Forests/Alianza Internacional de los Pueblos Indígenas y Tribales de los Bosques Tropicales; International Indian Treaty Council (IITC); Na Koa Ikaika KaLahui Hawaii; First Nations Summit; Union of British Columbia Indian Chiefs; Network of the Indigenous Peoples-Solomons (NIPS); Federation of Saskatchewan Indian Nations; Treaty 4 Chiefs; Innu Council of Nitassinan; Kus Kura S.C.; Haudenosaunee of Kanehsatà:ke; Kakisiwew Treaty Council; Ochapowace Cree First Nation; Cowessess Cree First Nation; First Peoples Human Rights Coalition; Canadian Friends Service Committee (Quakers); Center for World Indigenous Studies; KAIROS: Canadian Ecumenical Justice Initiatives" (Statement presented to the Expert Mechanism on the Rights of Indigenous Peoples Fourth session, Geneva 11-15 July 2011) [unpublished], online: Canadian Friends Service Committee < http://quakerservice.ca/wpcontent/uploads/2011/07/Expert-MECHANISM-Study-re-IPs-Rt-to-Participate-ORAL-Statement-GCC-etal-July-12-11.pdf $>$ at 2, paras $10 \& 11$ [Gabriel] [emphasis added].
} 
This recognition of Indigenous peoples' international rights to fully participate in environmental decision-making is absent from the law of transboundary rivers.

This observation was further reinforced by my research regarding the TsangpoBrahmaputra River Basin that runs through the Himalayan Mountains of the Tibet Autonomous Region in China and flows through India, Bhutan and Bangladesh. Governance of this transboundary river is complicated by the complexity and magnitude of the issues confronting the Indigenous peoples of Tibet, as well as the ongoing dispute between China and India over portions of Arunchal Pradesh, all of which centre around conflicting claims of sovereignty. In this context, the requirement of unambiguous sovereign status in order to access the international law of transboundary rivers may actually exacerbate violent conflicts in the area and undermine the status of Indigenous peoples' who have never ceded their sovereignty over these regions.

Together, the case examples of the Columbia and the Tsangpo-Brahmaputra Rivers prompted me to critically examine the intersection between the international law of transboundary watercourses, the doctrine of sovereignty, and the international rights of Indigenous peoples. The issues surrounding these two rivers brought into focus the effect that the doctrine of sovereignty has had in transboundary water law in excluding Indigenous peoples from participating in international transboundary negotiations.

The United Nations Convention on the Law of the Non-Navigational Uses of International Watercourses [UN Watercourse Convention] is intended as a mechanism to govern the economic and political relationships and agreements between sovereign states 
only and does not recognize the rights of non-state actors. ${ }^{15}$ While at first glance this may seem standard for an international convention, it is problematic for two reasons:

i) it does not acknowledge and integrate the rights of Indigenous peoples as ratified in a myriad of other international instruments; and

ii) it does not provide any mechanism for dispute resolution for conflicts regarding transboundary waters that are outside of a well-defined and clearly delineated state-to-state relationship.

Rather than help reduce conflict over these rivers, the state-centric focus of the $U N$ Watercourse Convention may actually serve to further entrench competition and conflict over territories in order to obtain or preserve the entitlements that come with sovereign status.

The UN Watercourse Convention is a particularly unique subject matter for an analysis of the doctrine of sovereignty in that it is directed at transboundary waters, which by their very nature defy claims of sovereign entitlement. Stephen C. McCaffrey $^{16}$, author of The Law of International Watercourses, $2^{\text {nd }}$ ed. (2007), considers the challenges that arise when attempting to apply the doctrine of territorial sovereignty to transboundary waters and observes that transboundary water defies ownership in that it is "more akin to clouds, winds and migratory birds than to land". ${ }^{17}$ In his role as special rapporteur to the United Nations International Law Commission during the drafting of the

\footnotetext{
${ }^{15}$ Convention on the Law of the Non-Navigational Uses of International Watercourses, opened for signature 21 May 1997, 36 ILM 700 (1997) (not yet in force) at Art 2 [UN Watercourse Convention].

${ }^{16}$ Professor McCaffrey is one of the world's foremost authorities on international water law. He was a member of the United Nations International Law Commission from 1982-91 and served as its chair during the 1987-88 session. He served as special rapporteur for the commission's draft articles on the law of the non-navigational uses of international watercourses, which formed the basis of the UN Watercourse Convention. See full biography online: Pacific McGeorge School of Law

<http://www.mcgeorge.edu/x7296.xml>.

${ }^{17}$ McCaffrey (2007), supra note 5 at 68.
} 
UN Watercourse Convention, McCaffrey made firsthand observations regarding the negotiation of the Convention. He perceives the equitable principles set out in the $U N$ Watercourse Convention as constituting a radical departure from the traditional notions of absolute territorial sovereignty. In 2008, McCaffrey stated that the UN Watercourse Convention "thoroughly rejects any notion that sovereignty over shared water resources is part of international law.... A right to share in a common resource is difficult, at best, to reconcile with the notion of 'sovereignty' over that resource."18 He further asserts that "[t]he notion of sovereignty over shared water is unsupported both in state practice and in the work of expert groups." ${ }^{, 19}$ McCaffrey also emphasizes the inclusive nature of $U N$ Watercourse Convention negotiations to emphasize its universal applicability. He states: ... the Convention will be of value whether or not it enters into force because it was negotiated in a forum in which virtually any interested state could participate, and therefore reflects the views of the international community on the subject. ${ }^{20}$

When viewed from a state perspective, the $U N$ Watercourse Convention is perceived by supporters and detractors alike as representing a landmark departure from the historical doctrine of sovereignty.

When viewed from the perspective of Indigenous peoples, however, sovereign status continues to be a barrier to accessing transboundary water law. As non-state actors, Indigenous peoples have no rights under the UN Watercourse Convention and are

\footnotetext{
${ }^{18}$ Stephen C McCaffrey "Introduction: Politics and Sovereignty over Transboundary Groundwater" (Paper presented to Proceedings of the Annual Meeting American Society of International Law Panel Discussion entitled "If Water Respects No Political Boundaries, Does Politics Respect Transboundary Waters?" (2008) 102 American Society of Int'1 L Proc 353, online: JSTOR <http://www.jstor.org/stable/25660314> at 354 [McCaffrey (2008)].

${ }^{19}$ Ibid at 355.

${ }^{20}$ McCaffrey (2007), supra note 5 at 376 [emphasis added]. Also at 359, McCaffrey observes that the Working Group, which drafted the UN Watercourse Convention, was open to participation by all member states within the United Nations as well as states that were only members of specialized agencies of the United Nations. This had the effect of allowing states such as Switzerland to participate in the drafting of the Convention even though they were not members of the United Nations.
} 
rarely mentioned in the legal discourse regarding transboundary rivers despite the overwhelming affirmation of international Indigenous rights by the majority of states. In this respect, the doctrine of sovereignty continues to dictate who may participate in the international law of transboundary rivers and which peoples are deemed to be members of the "international community" that are entitled to share in the transboundary water resources. $^{21}$

The UN Watercourse Convention was opened for signature on 21 May 1997 and has been endorsed by 24 countries. ${ }^{22}$ It has not yet come into force because it lacks the 35 signatories required for ratification. Notably, UNDRIP was initially adopted on 13 September 2007 by 144 countries and as of January 2012 has been endorsed by 150 countries. ${ }^{23}$ Numerous provisions of UNDRIP affirm an indirect right to water as incidental to Indigenous peoples' rights to cultural integrity and economic development. Articles 25 and 32(2) expressly affirm Indigenous peoples' rights to water and require states to obtain Indigenous peoples' "free and informed consent" prior to any development that impacts water in their territories. ${ }^{24}$ Given the overwhelming state support for UNDRIP, does the UN Watercourse Convention truly reflect the views of the

\footnotetext{
21 Ibid.

${ }^{22}$ UN Treaty Collections, "Convention on the Law of the Non-Navigational Uses of International Watercourses New York, 21 May 1997” (Status as at 2 January 2012), online: UN Treaty Collections <http://treaties.un.org/Pages/ViewDetails.aspx?src=UNTSONLINE\&tabid=2\&mtdsg_no=XXVII$12 \&$ chapter $=27 \&$ lang=en\#Participants $>$.

${ }^{23}$ UNDRIP, supra note 13. UNDRIP was originally endorsed by 144 countries in favour, four countries voting against and 11 countries abstaining. The four countries that voted against UNDRIP were Canada, the United States, Australia and New Zealand. All four have since endorsed UNDRIP. The countries abstaining were: Azerbaijan, Bangladesh, Bhutan, Burundi, Colombia, Georgia, Kenya, Nigeria, Russian Federation, Samoa and Ukraine. Columbia and Samoa have since expressed their support of the Declaration. See UN Bibliographic Information System, United Nations Declaration on the Rights of Indigenous Peoples: resolution / adopted by the General Assembly, online: UN <http://unbisnet.un.org:8080/ipac20/ipac.jsp?profile=voting\&index=.VM\&term=ares61295>. Also see UN PFII, "United Nations Declaration on the Rights of Indigenous Peoples Adopted by the General Assembly 13 September 2007”, online: United Nations <http://www.un.org/esa/socdev/unpfii/en/declaration.html>.

${ }^{24}$ UNDRIP, supra note 13.
} 
international community on the subject of international water law? If international values have changed, then the UN Watercourse Convention also needs to be updated to reflect the international rights of Indigenous peoples.

In this thesis, I contend that state-centric approaches to transboundary water law fail to recognize Indigenous peoples' international rights or the potentially pivotal role that Indigenous legal theory and Indigenous peoples' knowledge might play in transcending conflict. The international community can transcend the conflict inherent in sovereign discourse by developing international water law in a manner that recognizes Indigenous peoples' rights to participate in decision-making regarding transboundary rivers and to gain access to regional dispute resolution mechanisms. This can be achieved on a 'without prejudice' basis such that the laws concerning shared water resources can evolve without adversely impacting any peoples' claim to sovereignty. ${ }^{25}$ If sovereign status remains a precondition to accessing and participating in transboundary water law, then the $U N$ Watercourse Convention effectively perpetuates imperialist values and the historical exclusion of Indigenous peoples from the international community.

While overcoming references to state sovereignty in international water law is a daunting task, a review of the history of Indigenous peoples' international rights in can provide us with insights about how to navigate the doctrine of sovereignty in international law. Hammer contends that international laws and norms regarding Indigenous peoples' status and position can provide an important bridge between questions regarding the human right to water and control over water as a resource, as well as issues relating to the environment. He states:

\footnotetext{
${ }^{25}$ Personal conversation with June McCue (2011).
} 
By considering indigenous peoples and their approaches to the land, we can begin to conceive of a holistic approach to water that goes beyond the sovereign dialogue pertaining to states and their territories. ${ }^{26}$

The primary objective of this thesis is to reconcile international water law with the international law of Indigenous peoples. In the next section, I set out my methodology for undertaking this research project and introduce critical race theory as the theoretical framework for this thesis.

\subsection{Theoretical Framework and Methodology}

The primary focus of this thesis is to deconstruct, decolonize and offer directions for reconstruction of the international law of transboundary rivers from Indigenous perspectives. Throughout this research, I have been guided by the question: What would an international law of transboundary rivers look like if it were drafted from the perspective of international Indigenous law and theory? To answer this question, I have adopted Critical Race Theory as my theoretical framework to critically examine the impact of the UN Watercourse Convention, its related discourse and the role of the doctrine of sovereignty upon Indigenous peoples.

\subsubsection{Critical Race Theory}

Law and order exist for the purpose of establishing Justice and ... when they fail in this purpose they become the dangerously structured dams that block the flow of social progress. ${ }^{27}$

Martin Luther King Jr. (1963)

\footnotetext{
${ }^{26}$ Leonard Hammer, "Indigenous People as a Catalyst for Applying the Human Right to Water" (2004) 10 International Journal on Minority and Group Rights 131 at 150.

${ }^{27}$ Martin Luther King in Carol Aylward, Canadian Critical Race Theory (Halifax: Fernwood Publishing 1999) at 14 [Aylward].
} 
In this thesis, I apply critical race theory as it applies to Indigenous peoples in international water law [Critical Race Theory]. At the core of Critical Race Theory is the goal of achieving social justice for historically oppressed groups. ${ }^{28}$ Mutua describes Critical Race Theory as “... a project of outsider jurisprudence” as it is primarily directed at "social justice for 'outsider' groups". ${ }^{29}$ While Critical Race Theory originally emerged within the context of the struggle of African-American peoples in the United States, it has emerged as a theoretical framework that is relevant for examining the experience of other oppressed minorities and Indigenous peoples. ${ }^{30}$

In Canadian Critical Race Theory (1999), Carol Aylward identifies the primary

themes of the theoretical framework as follows:

... a contextual analysis which positions the experiences of oppressed peoples at its center, a deconstruction which asks the question, How does this legal doctrine rule, principle, policy or practice subordinate the interests of Black people and other people of colour? And ultimately, a reconstruction which understands the "duality" of law, recognizing both its contribution to the subordination of Blacks and other people of colour and its transformative power. ${ }^{31}$

An accompanying methodology has emerged that is comprised of a deconstruction of the law, a presentation of alternatives and a reconstruction of the law in a manner that remedies the injustice. ${ }^{32}$ Applied to this thesis, the methodology involves:

\footnotetext{
${ }^{28}$ Christopher Dunbar Jr, "Critical Race Theory and Indigenous Methodologies" in Norman K Denzin, Yvonna S Lincoln, \& Linda Tuhiwai Smith, eds, Handbook of Critical and Indigenous Methodologies (Thousand Oaks: SAGE Publications Ltd., 2008) 85 at 93 [Smith (2008)].

${ }^{29}$ Makau W Mutua, "Critical Race Theory and International Law: The View of an Insider-Outsider" (2000)

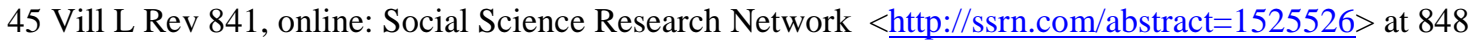
[Mutua].

${ }^{30}$ Ibid at $841-842$.

${ }^{31}$ Aylward, supra note 27 at 34-35.

${ }^{32}$ Ibid. Aylward offers the following methodology: "Critical Race methodology requires a deconstruction of legal rules, principles and policies and it challenges the so-called "neutrality" and "objectivity" of laws that oppress Blacks and other people of colour. Deconstruction is designed to confront subtle forms of discrimination perpetuated by law. Critical Race Theory attempts to expose the ordinariness of racism and to validate the experiences of people of colour, which are important for understanding laws that perpetuate
} 
a deconstruction of the law of transboundary rivers by confronting the role of the legal doctrine of sovereignty within international water law and demonstrating how it operates to subordinate Indigenous peoples;

(ii) a presentation of alternate narratives regarding Indigenous peoples' relationships to sovereignty which together "tell the story" 33 of the racial antagonism that is at the center of the legal principle in question; and

(iii) a reconstruction of the international law of transboundary rivers through a return to ethics and coalition building.

International law is not beyond the reach of Critical Race Theory. Andrews emphasizes the ability of Critical Race Theory "to unmask the veneer of equality and neutrality of international law and to expose international law’s colonial trappings.” Mutua identifies the role that Critical Race Theory can play in challenging the supposed "universality" 35 of international law. Proponents of international law tend to present it as a universal system of laws that is premised on equality and neutrality. Mutua asserts that international law by its very nature is "Eurocentric in that it issues from European thought, culture and experiences. This specificity denies international law universality." 36 Critical Race Theory provides a framework for deconstructing how colonialism and cultural bias have infiltrated international legal systems and institutions and challenges the supposed universality of international laws. Mutua contends that the application of Critical Race Theory to international law reveals that:

their disenfranchisement. ... Critical Race Theory also employs "narrative," or storytelling. Narrative functions in a number of ways. It can allow lawyers and others to "tell the story" of their clients and the Black experience of racism and subordination. ... Narrative can debunk the myths of neutrality and objectivity by placing emphasis upon the confrontational nature of an encounter ... in its social and historical context of racial discrimination. ... The final stage in Critical Race methodology is reconstruction. What are the alternatives (if any) to the existing doctrine, legal rule, principle or practice that will advance the cause of Black people?"

${ }^{33}$ Ibid.

${ }^{34}$ Penelope Andrews, "Making Room for Critical Race Theory in International Law: Some Practical Pointers" (2000) 45 Vill L Rev 855 at 858.

${ }^{35}$ Mutua, supra note 29 at $844-845$.

${ }^{36}$ Ibid at 841 . 
... international law has largely been developed and deployed as a vehicle for advancing particular interests, for the benefit of specific peoples, cultures and regions and, as a consequence, for the detriment of particular interests, peoples, cultures and regions. ${ }^{37}$

Beyond deconstruction, Critical Race Theory also holds the promise of reconstructing international law in a manner that reflects true universality and social justice. Mutua asserts that, "international law need not be an instrument for exclusion and exploitation" and that "it can and should speak to more noble ideals". ${ }^{38}$ Critical Race Theory therefore brings with it an "emancipatory potential ... that can be tapped and deployed as part of the project for the reconstruction of international law.",39

I have adopted Critical Race Theory and methodology from the perspective of Indigenous peoples recognizing that they have been historically oppressed and disenfranchised. Specifically, my research challenges the tendency of international water law and the mainstream discourse associated with transboundary water law to subordinate and marginalize the rights and interests of Indigenous peoples. This thesis demonstrates how ongoing colonial presumptions about the primacy of state sovereignty in the international law of transboundary rivers have operated to exclude Indigenous peoples' from the social contract that forms the basis of international water law. Critical Race Theory provides a lens through which to critique transboundary water law from the perspective of Indigenous peoples and to envision how international water law could be reconstructed if it were founded upon post-imperial values such as mutual respect. ${ }^{40}$

\footnotetext{
${ }^{37}$ Ibid at 845 .

38 Ibid.

${ }^{39}$ Ibid.

${ }^{40}$ Alfred identifies "three post-imperial values: consent, mutual recognition, and cultural continuity." See Taiaiake Alfred, "Sovereignty” in Joanne Barker, ed, Sovereignty Matters: Locations of Contestation and Possibility in Indigenous Struggles for Self-Determinism (Lincoln: University of Nebraska Press, 2005) 33 at 38 [Alfred (2005)] [J Barker].
} 
Respect is a key theme in Indigenous scholarship. In her well received book Decolonizing Methodologies: Research and Indigenous Peoples (2002), Linda Tuhiwai

Smith writes:

The term 'respect' is consistently used by indigenous peoples to underscore the significance of our relationships and humanity. Through respect the place of everyone and everything in the universe is kept in balance and harmony. Respect is a reciprocal, shared, constantly interchanging principle which is expressed through all aspects of social conduct. Haig-Brown and Archibald write that, "to be in harmony with oneself, other members of the animal kingdom, and other elements of nature requires that First Nations people respect the gift of each entity and establish and maintain respectful, reciprocal relations with each'. The denial by the West of humanity to indigenous peoples, the denial of citizenship and human rights, the denial of the right to self-determination - all these demonstrate palpably the enormous lack of respect which has marked the relations of indigenous and non-indigenous peoples."41

To restore dignity overall, reconstruction of international water law must accord with respect for both Indigenous and non-Indigenous peoples. ${ }^{42}$

The current chapter outlines the methodology and theoretical framework of this thesis. Chapter 2 sets out to deconstruct international water law. This chapter introduces the UN Watercourse Convention and related mainstream discourse and demonstrates how the doctrine of sovereignty operates to exclude Indigenous peoples from participating in international water law and discourse. Chapter 2 also provides two case examples that locate Indigenous peoples and interests within the complex geopolitics of two transboundary rivers: the Columbia River and the Tsangpo-Brahmaputra River. The first case example demonstrates how Indigenous peoples have been adversely impacted by past transboundary developments and how their ongoing legal claims and future interests

\footnotetext{
${ }^{41}$ Linda Tuhiwai Smith, Decolonizing Methodologies: Research and Indigenous Peoples (New Zealand: University of Otago Press, 2002) at 120 [Smith (2002)]. Also see Alfred (2005), supra note 40 at 46 where he observes that, "Indigenous perspectives offer alternatives, beginning with the restoration of a regime of respect."

${ }^{42}$ Personal conversation with D. Anthony Knox (2011).
} 
are routinely relegated to a secondary domestic concern. The second case example illustrates the extreme vulnerability of Indigenous peoples and the geopolitical tensions that are exacerbated by linking rights regarding transboundary water with sovereign status. This chapter will demonstrate how the entrenchment of the doctrine of sovereignty in international water law undermines the internationally protected rights of Indigenous peoples and potentially fuels conflict in regions where sovereignty is disputed or unresolved. ${ }^{43}$

Chapter 3 provides alternative narratives and perspectives regarding sovereignty. This chapter offers a brief history of the concept of sovereignty in classical Western legal discourse to show how it has been manipulated as a tool of Western lawmakers to dominate Indigenous peoples and exploit resources. Chapter 3 then undertakes a literature review of Indigenous experiences and perspectives of sovereignty. This chapter will show that the concept of sovereignty is not a fixed absolute but rather is a socially and culturally derived concept that has been shaped by lawmakers for specific political purposes. Once we acknowledge sovereignty as a social construct, we can imagine the reconstruction of new laws grounded in mutual respect.

Chapter 4 offers proposals for the reconstruction of international water law in a manner that is inclusive of Indigenous perspectives. This chapter considers how Indigenous peoples have successfully asserted their rights within international law and

\footnotetext{
${ }^{43}$ The deconstruction that follows in the next chapter involves a critical examination of the $U N$ Watercourse Convention and related discourse. While I do make passing reference to the International Law Commission's draft articles on the law of transboundary aquifers, I do not critique those draft articles in this thesis. (See International Law Commission, Draft articles on the Law of Transboundary Aquifers, (2008) UN GAOR Sixty-third Session, Supp No. 10, UN Doc A/63/10, online: UN <http://untreaty.un.org/ilc/texts/instruments/english/draft\%20articles/8_5_2008.pdf> [Law of Transboundary Aquifers].) Likewise, I have not undertaken a critical analysis of general water governance theories such as Integrated Resource Water Management (IRWM) theories or Integrated Water Initiatives (IWI), although I do make reference to them in some instances. Finally, this thesis is concerned solely with international law of transboundary rivers and does not attempt to analyze the national laws of any one state.
} 
reviews several international instruments that recognize and affirm Indigenous peoples' rights. I then consider several proposals for the reconstruction of international water law. In my view, simply amending the $U N$ Watercourse Convention to reference UNDRIP and other Indigenous rights will not achieve genuine reconciliation. I conclude by proposing a vision for a new and radically inclusive international convention, which encompasses and integrates international Indigenous laws and values through a return to ethics and coalition building. I contend that the international law of Indigenous peoples' rights together with the human right to water must form the pillars of international water law reform, effectively displacing the doctrine of sovereignty currently governing transboundary water conflict. In the next section, I reflect upon my own role as a nonIndigenous person seeking social justice for Indigenous peoples.

\subsection{Deconstructing My Settler Self: On Becoming an Ally in Water Law}

Given that I have adopted Critical Race (Indigenous) Theory as my theoretical framework of my thesis, it is relevant to acknowledge that I am not Indigenous. I am a second-generation Canadian of European-settler heritage. Several members of my family have dedicated their professional and personal lives to working in close partnership and friendship with Indigenous peoples. My father, also of European descent, has been a band manager and consultant to British Columbian First Nations for the last 10 years until his retirement. My mother, a lifelong educator, earned her doctorate at the age of 65 researching and documenting the strength and resilience of First Nations women as community leaders in education. Other family members work in the field of First Nations issues in counseling as well as refugee advocacy for Indigenous peoples arriving in Canada. Others have lived or continue to live on First Nations reserves. As a young 
child, I took annual vacations to visit family on a remote coastal reserve. I am shaped by my settler heritage and I have also been raised to think deeply about the ongoing social and legal reconciliation of Indigenous and non-Indigenous peoples' traditions.

Increasingly, non-Indigenous scholars are exploring the issues that arise as a nonIndigenous person committed to pursuing social justice for Indigenous peoples. In Unsettling the Settler Within, Paulette Regan challenges non-Indigenous peoples to confront their privileged status as settlers:

The significant challenge that lies before us is to turn the mirror back upon ourselves and to answer the provocative question posed by historian Roger Epp regarding reconciliation in Canada: How do we solve the settler problem? ${ }^{44}$

In "Ethical Space of Engagement", Cree ethicist, Willie Ermine shares a similar perspective on the need for non-Indigenous peoples to internalize the observable injustices:

Currently, the situation, and very often the plight of Indigenous peoples, should act as a mirror to mainstream Canada. The conditions that Indigenous peoples find themselves in are a reflection of the governance and legal structures imposed by the dominant society. Indeed, what the mirror can teach is that it is not really about the situation of Indigenous peoples in this country, but it is about the character and honor of a nation to have created such conditions of inequity. It is about the mindset of a human community refusing to honor the rights of other human communities. ${ }^{45}$

Barker observes that, to the extent that Indigenous peoples are confronted with the imperative to overcome historic injustices, settler peoples are equally confronted with the

\footnotetext{
${ }^{44}$ Paulette Regan, Unsettling the Settler Within (Vancouver: UBC Press, 2010) at 11 [Regan].

${ }^{45}$ Willie Ermine, "The Ethical Space of Engagement" in (2007) 6 Indigenous L J 193 at 200 [Ermine (2007)].
} 
imperative to overcome the adverse impacts of colonization in order to realize freedom and dignity. ${ }^{46}$

Regan contemplates what it means to become a "settler-ally" and concludes that it requires her to "continuously confront the colonizer-perpetrator in myself, interrogating my own position as a beneficiary of colonial injustice." ${ }^{47}$ Regan notes that this commitment to being an ally is necessarily an uncomfortable and difficult journey.

Those settlers who think that no reconciliation is necessary or that a cheap reconciliation is enough may never aspire to change the socio-political relationships, structures and institutions of colonialism. Taiaiake Alfred reminds us that, "from the perspective of the Onkwehonwe struggle, the enemy is not the white man in racial terms, it is a way of thinking with an imperialist's mind." Thus it is possible and necessary for those settlers who would be Indigenous allies to reject the imperialist's mind in favour of living in truth, accepting that we will struggle and be discomforted and unsettled. $^{48}$

Relying upon Regan's framework, Barker states that to become a meaningful ally, a Settler must resist the temptation to "re-establish comfort" and instead continue to ask "What do we do?" from a "profoundly uncomfortable place". 49 This inquiry must continue to be guided by "an honest inquiry into the causes and effects of colonialism, and our individual responsibility for colonization". ${ }^{50}$ Barker concludes that being a settler-ally involves recognizing the place of privilege and power that one holds due to one's settler status and then placing those resources at the disposal of Indigenous peoples.

\footnotetext{
${ }^{46}$ Adam Barker, "From Adversaries to Allies: Forging Respectful Alliances between Indigenous and Settler Peoples" in Lynn Davis, ed, Alliances: Re/Envisioning Indigenous-Non-Indigenous Relationships (Toronto: University of Toronto Press, 2010) 316 at 318 [A Barker].

${ }^{47}$ Regan, supra note 44 at 236

${ }^{48}$ Ibid at 233

${ }^{49}$ A Barker, supra note 46 at 323.

${ }^{50}$ Ibid.
} 
It also requires allies to give up their need to control Indigenous peoples' actions or goals. $^{51}$

From an academic perspective, research that involves Indigenous perspectives should set out to make a positive difference for Indigenous peoples. ${ }^{52}$ Regan concludes that:

.... we must also work in respectful and humble partnership with Indigenous people to generate critical hope - vision that is neither cynical nor utopian but rooted in truth as an ethical quality in the struggle for human dignity and freedom. $^{53}$

As a settler, I acknowledge that I inevitably carry my cultural biases with me even while I try to overcome historical and ongoing prejudices. While I am aware of the possibility that I could misinterpret or misunderstand the words of Indigenous scholars, I have also been raised to believe that it is important to find the courage to cross these bridges of understanding in an effort to initiate dialogue on issues that are vital to humanity. ${ }^{54} \mathrm{My}$ research is my attempt to actively listen to what Indigenous scholars have said on these issues while acknowledging the limitations of my own understanding. ${ }^{55}$ While Indigenous lawyers and advocates are bound to bring a clearer perspective on this subject, I embark on this project with Robert B. Porter's encouragement that 'the bigger issue is commitment to bridging the cultural chasm and serving the needs of the client"

\footnotetext{
${ }^{51}$ Ibid at 324

${ }^{52}$ Smith (2002), supra note 41 at 191.

${ }^{53}$ Regan, supra note 44 at 237.

${ }^{54}$ Sandra Lynne Umpleby, Crossing Bridges: The Educational Leadership of First Nations Women (PhD Thesis, Education, University of Victoria, 2007) [Umpleby].

${ }^{55}$ Active listening involves carefully listening to what is being said and then summarizing and reflecting back what has been heard to demonstrate understanding.

${ }^{56}$ Robert B Porter, "Strengthening Tribal Sovereignty Through Peacemaking: How the Anglo-American Legal Tradition Destroys Indigenous Societies” (1997) 28 Colum Hum Rts L Rev. 235, reprinted in RO Porter, supra note 10, 557 at 570 [RB Porter "Peacemaking"].
} 


\subsection{Conclusion}

The United Nations cautions that governance of our limited freshwater resources in the face of escalating global demand is one of the most pressing issues facing the world in coming decades. ${ }^{57}$ Yet, international water law "remains remarkably weak to remedy problems involving international rivers". 58 Moreover, international law of transboundary rivers and related mainstream discourse is out of step with post-imperialist values that have been affirmed in other international instruments. This thesis critically examines the intersecting relationship between international water law, the doctrine of sovereignty and Indigenous peoples. By adopting Critical Race Theory as my theoretical framework, I deconstruct the UN Watercourse Convention and demonstrate how the requirement of sovereign status operates to systemically exclude Indigenous peoples from participating in the application and development of transboundary water law at the international level. I then offer alternatives to our traditional understanding of sovereignty by considering Indigenous peoples' relationship with sovereign status in order to demonstrate that sovereignty is nothing more than a man-made construct that has been designed and manipulated for political and economic purposes. Finally, I consider how Indigenous laws, wisdom and values might be accessed to inform a reconstruction of international water law that supports the mutual respect and dignity of all peoples in the governance of transboundary water.

\footnotetext{
${ }^{57}$ See generally, "UN-Water Documents", online: UN-Water <http://www.unwater.org/>.

${ }^{58}$ Paisley \& Hearns, supra note 7 at 7.
} 


\section{Chapter 2: International Water Law: A Deconstruction}

The first step in a Critical Race Theory analysis is to deconstruct the law or legal principle in question from the perspective of the oppressed group to demonstrate how it has operated to "subordinate the interests" 59 of that group. The first part of this chapter reviews the international law of transboundary watercourses and examines the central role that the doctrine of sovereignty has played in the formation of international guidelines regarding transboundary rivers. From a state perspective, the $U N$ Watercourse Convention is perceived as progressive in its departure from the strict application of absolute territorial sovereignty and codification of a form of "sovereign equality" ${ }^{0}$ vis-àvis shared watercourses. However, from an Indigenous perspective, the emphasis upon sovereignty in international water law operates to prevent the application of established water ethics to Indigenous peoples. Because they are not recognized by states as possessing sovereign status within international law, Indigenous peoples are excluded from membership in the international community that is guiding the evolution of international water law principles. This chapter locates Indigenous peoples within international water law and within the context of two transboundary rivers: the Columbia and the Tsangpo-Brahmaputra. The chapter concludes by considering how the emphasis on sovereignty in international water law not only fails to acknowledge and protect Indigenous peoples' affirmed international rights but may also exacerbate conflict in areas where disputed or unresolved claims over territory fuel ongoing geopolitical conflict.

\footnotetext{
${ }^{59}$ Aylward, supra note 27 at 34-35.

${ }^{60}$ UN Watercourse Convention, supra note 15. Article 8.1 states that "Watercourse States shall cooperate on the basis of sovereign equality, territorial integrity and mutual benefit and good faith in order to attain optimal utilization and adequate protection of an international watercourse."
} 


\subsection{International Water Law and the Doctrine of Sovereignty}

By their very nature, transboundary rivers are focal points for conflict. ${ }^{61}$ All peoples require water to survive and yet demands over limited supplies of freshwater are increasing as a result of population growth, climate change. McIntyre considers the potential for conflict in terms of increasing population growth and anticipated demand upon transboundary rivers:

Taking population growth alone, the United Nations has issued startling predictions for several major international river systems. For example, along the Tigris and Euphrates, the populations of Iraq and Syria are predicted to more than double, and that of Jordan to nearly triple, between 1955 and 2025. On the Nile, the population of Egypt is predicted to rise from 60-90 million and that of Sudan to more than double from 24-56 million in the same period. Similarly on the Ganges, the population of Bangladesh is expected to nearly double and that of India to increase by 50 percent. More recently, the WCD has estimated that world population will reach a peak of between 7.3 billion and 10.7 billion around 2050 before total population begins to stabilize or fall and, further, that by 2025 there will be approximately 3.5 billion people living in water-stressed countries. ${ }^{62}$

Sufficient water flows are required for irrigation, hydroelectricity, fish populations and ecosystem health all of which will be further impacted by the demands of population growth. In addition to increased demand, transboundary rivers are subject to competing state development projects, the adverse impacts of pollution, and reduced flows due to melting glaciers and climate change.

Beach et al. (2000) analyzed dozens of transboundary rivers to identify patterns of possible water conflict with the purpose of helping to anticipate emerging conflict. The authors describe the typical pattern of emerging conflict as follows:

\footnotetext{
${ }^{61}$ Owen McIntyre, Environmental Protection of International Watercourses under International Law (Great Britain: MPG Books Ltd., 2007) at 9 [McIntyre].

${ }^{62}$ Ibid at 10.
} 
...riparians of an international basin implement water development projects unilaterally first on water within their own territory, in attempts to avoid the political intricacies of the shared resources. At some point, as water demand approaches supply, one of the riparians, generally the regional power, will implement a project that impacts on at least one of its neighbours. ... In the absence of relations or institutions conducive to conflict resolution, the project that impacts on one's neighbours can become a flashpoint, and conflict among various parties is imminent. ${ }^{63}$

Despite the critical importance of fresh water, international water law is ill equipped to address or remedy conflicts over transboundary rivers. ${ }^{64}$

The UN Watercourse Convention is the only international treaty directed at transboundary rivers. ${ }^{65}$ The Convention outlines procedural and substantive guidelines for riparian member states to establish agreements for the optimal and sustainable utilization of transboundary watercourses. Developed over 27 years by the United Nations International Law Commission, it has not yet entered into force due to a lack of signatories. $^{66}$

Despite its failure to be ratified, the Convention is accepted as setting out the customary international law of transboundary rivers and codifying "the fundamental principles and rules governing the rights and duties of watercourse states." ${ }^{67}$ While bilateral and multilateral agreements between states remain the primary source of customary international law, the UN Watercourse Convention is considered a guiding document and establishes "a basis for future international treaties". ${ }^{6}$

\footnotetext{
${ }^{63}$ Beach et al, supra note 4 at 40.

${ }^{64}$ Paisley \& Hearns, supra note 7.

${ }^{65}$ Brown \& Odeh, supra note 9 at 7.

${ }^{66}$ As of January 2, 2012, there were 24 Parties to the Convention. See UN Treaty Collections, supra note 22.

${ }^{67}$ Gihan Indraguptha, "Water as a Human Right: International Dimension" (2011) [unpublished, archived at University of British Columbia Lui Institute of Global Studies] at 7 [Indraguptha]. Also see Grzybowski et al, supra note 6; Brown \& Odeh, supra note 9 at 14.

${ }^{68}$ Brown \& Odeh, ibid at 7.
} 


\subsubsection{UN Watercourse Convention}

The customary international law of transboundary watercourses, as reflected in the UN Watercourse Convention, is limited in its scope to the rights and obligations of sovereign states vis-à-vis other sovereign states. Article 2 of the Convention defines the following terms:

"Watercourse" means a system of surface waters and groundwaters constituting by virtue of their physical relationship a unitary whole and normally flowing into a common terminus;

"International watercourse" means a watercourse, parts of which are situated in different States;

"Watercourse State" means a State Party to the present Convention in whose territory part of an international watercourse is situated, or a Party that is a regional economic integration organization, in the territory of one or more of whose Member States part of an international watercourse is situated; "Regional economic integration organization" means an organization constituted by sovereign States of a given region, to which its Member States have transferred competence in respect of matters governed by the present Convention and which has been duly authorized in accordance with its internal procedures, to sign, ratify, accept, approve or accede to it."

Article 4(1) states that, "[e]very Watercourse State is entitled to participate in the negotiation of and to become a party to any watercourse agreement that applies to the entire international watercourse, as well as to participate in any relevant consultations." Several provisions of the Convention set out procedural guidelines for cooperation, information sharing, notification of possible adverse effects, consultation, protection of ecosystems and responses to emergency conditions. Article 33 sets out a dispute resolution procedure whereby Member Watercourse States agree to submit disputes to the International Court of Justice or submit to the arbitration procedures set out in the Appendix to the Convention. The above definitions and provisions serve to limit the scope of the UN Watercourse Convention to the relationships between states. It does not

\footnotetext{
${ }^{69}$ UN Watercourse Convention, supra note 15 at Art 2.

${ }^{70}$ Ibid at Art 4(1).
} 
provide any recourse or mechanisms for dispute resolution for non-state actors such as

Indigenous peoples. Nor are the equitable principles contained in the Convention

intended to have any application to non-state actors.

In addition to the procedural guidelines, the UN Watercourse Convention codifies

two key substantive principles: (1) the principle of equitable and reasonable utilization,

and (2) the obligation not to cause significant harm to any party. ${ }^{71}$ Article 5 and Article

7 state:

Article 5 Equitable and reasonable utilization and participation

Watercourse States shall in their respective territories utilize an international watercourse in an equitable and reasonable manner. In particular, an international watercourse shall be used and developed by watercourse States, with a view of attaining optimal and sustainable utilization thereof and benefits therefrom, taking into account the interests of the watercourse States concerned, consistent with adequate protection of the watercourse. Watercourse States shall participate in the use, development and protection of an international watercourse in an equitable and reasonable manner. Such participation includes both the right to utilize the watercourse and the duty to cooperate in the protection and development thereof, as provided in the present Convention.

Article 7 Obligation not to cause significant harm

Watercourse States shall, in utilizing an international watercourse in their territories, take all appropriate measures to prevent the causing of significant harm to other watercourse States.

Where significant harm nevertheless is caused to another watercourse State, the States whose use causes such harm shall, in the absence of agreement to such use, take all appropriate measures, having due regard for the provision of article 5 and 6, in consultation with the affected State, to eliminate or mitigate such harm and, where appropriate, to discuss the question of compensation.

The equitable utilization and no-harm principles are perceived as an attempt to provide a

"dynamic process" for equitably balancing the rights and duties of upstream and

\footnotetext{
${ }^{71}$ Ibid at Art 5 \& 7. Also see Richard Paisley, "Adversaries into Partners: International Water Law and the Equitable Sharing of Downstream Partners” (2002) 3 Melbourne J of Int'1 L 280 [Paisley]; Brown \& Odeh, supra note 9 at 14. For a full list of rules governing transboundary rivers, see McCaffrey (2007), supra note 5 at 384-480.
} 
downstream riparian states. ${ }^{72}$ These principles have evolved as a reflection of states' competing perspectives on the proper duties and obligations that should attach to the doctrine of sovereignty. ${ }^{73}$ Together, they reflect recognition by states that, within the context of transboundary waters, the limitation upon absolute territorial sovereignty is justified on principles of fairness and equity. ${ }^{74}$

\subsubsection{The Doctrine of Sovereignty}

The doctrine of absolute territorial sovereignty in international law provides that sovereign nations have the exclusive right to the use and control of the land and resources within their borders. ${ }^{75}$ However, the strict application of the doctrine of sovereignty to shared water resources, while tempting, gives rise to "obvious difficulties". ${ }^{76}$ Competing theories regarding the rights and duties which should exist between states in international water law have given rise to debate about the appropriate degree of sovereignty that should apply to shared water resources, whether that is conceived of as absolute territorial sovereignty, absolute territorial integrity, limited territorial sovereignty or community of interests. $^{77}$

The doctrine of absolute territorial sovereignty provides that each sovereign state has exclusive jurisdiction over the land and resources within its borders, "regardless of any transboundary consequences". ${ }^{78}$ While absolute territorial sovereignty is not upheld

\footnotetext{
${ }^{72}$ McCaffrey (2007), supra note 5 at 405 and more generally at Chapter 10-11; Thorson, supra note 7 at 496-497; McIntyre, supra note 61 at 76.

73 Thorson, ibid.

${ }^{74}$ Katherine Jane Stoeckel, Economics and the Equitable Utilization of Transboundary Freshwater (LLM Thesis, University of British Columbia, Faculty of Law, 2004, [unpublished] at 45 [Stoeckel].

${ }^{75}$ Thorson, supra note 7 at 493.

${ }^{76}$ McCaffrey (2008), supra note 18 at 354.

77 Thorson, supra note 7 at 494; McCaffrey (2007), supra note 5 at Chapter 5: The Theoretical Basis of International Watercourse Law: An Examination of the Four Principled Theories.

78 Thorson, ibid. Also see, McCaffrey (2007), ibid at 112-126.
} 
in customary international water law, it remains an important and influential underlying principle of international law. ${ }^{79}$ It is typically adopted as the initial negotiating position of powerful upstream states.

On the other end of the spectrum, the principle of absolute territorial integrity supports the argument that a state may not impact "the natural flow of water to the downstream State." ${ }^{80}$ Downstream states tend to adopt the principle of absolute territorial integrity as their opening negotiating position. McCaffrey contrasts the two competing theories as follows:

While the doctrine of absolute territorial sovereignty insists upon the complete freedom of action of the upstream state, that of absolute territorial integrity maintains the opposite: that the upstream state may do nothing that might affect the natural flow of the water into the downstream state. $^{81}$

The "middle ground" approach is the principle of limited territorial sovereignty, a generally accepted principle of international water law that acknowledges both rights and duties. ${ }^{82}$ It is "substantively interpreted as the right to territorial sovereignty and the corollary duty not to cause significant harm to the sovereign rights of other States." 83

A fourth theoretical perspective is that international watercourses are the common property of the states that share the watercourse. ${ }^{84}$ The concept is derived from the notion "that a community of interest in the water is created by the natural, physical unity of a watercourse." ${ }^{, 85}$ Grotius promoted the concept of a river as a common public

\footnotetext{
${ }^{79}$ Thorson, ibid.

${ }^{80} \mathrm{Ibid}$ at 496.

${ }^{81}$ McCaffrey (2007), supra note 5 at 126.

${ }^{82}$ Thorson, supra note 7 at 496.

${ }^{83}$ Ibid at 497.

${ }^{84}$ McCaffrey (2007), supra note 5 at 156-158.

${ }^{85} \mathrm{Ibid}$ at 148 [emphasis added].
} 
property in the early $17^{\text {th }}$ century. ${ }^{86}$ McCaffrey cites Henry Farnham's work [1904] as

follows:

A river which flows through the territory of several states or nations is their common property ... It is a great natural highway conferring, besides the facilities of navigation, certain incidental advantages, such as fishery and the right to use the water for power or irrigation. Neither nation can do any act which will deprive the other of the benefits of those rights and advantages. ... The gifts of nature are for the benefit of mankind, and no aggregation of men can assert and exercise such right and ownership of them as will deprive others having equal rights, and means of enjoyment. ... [T]he common right to enjoy the bountiful provision of Providence must be preserved. ... ${ }^{87}$

In the Oder River decision (1929), the Permanent Court of International Justice recognized the "community of interests" in the river shared by the riparian states:

[the] community of interest in a navigable river becomes the basis of a common legal right, the essential features of which are the perfect equality of all riparian States in the use of the whole course of the river and the exclusion of any preferential privilege of any one riparian State in relation to the others... ${ }^{88}$

In the Gabč́kovo-Nagymaros case (1997), the International Court of Justice confirmed that a community of interests applies to non-navigational uses as well as navigational uses of a river. ${ }^{89}$ McCaffrey observes that while there is little ambiguity about the meaning and application of concepts such as absolute territorial sovereignty, absolute territorial integrity and limited territorial sovereignty, the notion of "community of

\footnotetext{
${ }^{86}$ Ibid at 157 .

${ }^{87} \mathrm{Ibid}$.

${ }^{88}$ Case Relating to the Territorial Jurisdiction of the International Commission of the Oder River (1929), Judgment of 10 September 1929, PCIJ (Series A No 23 -Series C No 17-11), online: International Water Law, <http://www.internationalwaterlaw.org/cases/river-oder.html $>$ [Oder River] as cited in McCaffrey (2007), supra note 5 at 389-390.

${ }^{89}$ Case Concerning the Gabčikovo-Nagymaros Project (Hungary/Slovakia), [1997] ICJ Judgment of 25 September 1997, International Court of Justice, online: International Court of Justice <http://www.icjcij.org/docket/files/92/7375.pdf> [Gabč́kovo-Nagymaros] as cited in McCaffrey (2007), supra note 5 at 161.
} 
interests" is still somewhat ambiguous in international water law. ${ }^{90}$ Further attention is required to define and understand "community" and "interests". 91 The notion of community may simply be an acknowledgement of the interdependence of states however, it is not simply a matter of "co-ownership" of a river. Rather it evokes the concepts of "shared governance" and "joint action". 92 McCaffrey notes that the community of interests approach does not inform international water law as much as it may provide insights to how states should work towards processes of community management. ${ }^{93}$ McCaffrey states,

... the legal obligations governing the relations between riparian states reinforce the existence of a community among them, even if they do not spring from that community. It will be seen later that these obligations include the duty to cooperate with other riparian states in the use, development and protection of an international watercourse system. ... the essence of cooperation is working together. In the context of international watercourses, this suggests a relationship between the co-riparians based upon respect for each other's interests. Respect would be manifested through observance of such principles as prior notification, consultation, and negotiation concerning changes in uses of the watercourse, and use of the watercourse in a manner that is equitable and reasonable vis-à-vis other riparian states. These are, in turn, all fundamental obligations of states sharing international fresh water resources. ${ }^{94}$

At its core, the principles of international water law reinforce mutual respect between sovereign members of the international community.

The UN Watercourse Convention is recognized for its departure from traditionally restrictive applications of absolute territorial sovereignty. Thorson characterizes the "equitable utilization" and "no-harm" principles adopted in the UN Watercourse

\footnotetext{
${ }^{90}$ McCaffrey (2007), ibid at 161-167.

${ }^{91}$ Ibid.

${ }^{92}$ Ibid at 165 .

${ }^{93}$ Ibid at 167 . Note that in this context, a community of interests approach is limited to a community of sovereigns.

${ }^{94}$ Ibid. [Italics original. Underline emphasis added.].
} 
Convention as a codification of "limited territorial sovereignty" as it attempts to balance both the rights and duties that accompany sovereignty. Some scholars have suggested that the principle of limited territorial sovereignty codified in the UN Watercourse Convention demonstrates a radical departure from the principle of absolute territorial sovereignty. McCaffrey takes the position that the UN Water Convention:

... thoroughly rejects any notion that sovereignty over shared water resources is part of international law. Moreover, the International Court of Justice in the Gabčíkovo-Nagymaros Project case also rejected such an idea. The Court referred to a state's "basic right to an equitable and reasonable sharing of the resources of an international watercourse." A right to share in a common resource is difficult, at best, to reconcile with the notion of "sovereignty" over that resource. ${ }^{95}$

While the UN Watercourse Convention received considerable support in the drafting stage,${ }^{96}$ its failure to come into force may be attributed to its attempt to codify a departure from absolute territorial sovereignty. China in particular voted against the Convention as an unacceptable rejection of absolute territorial sovereignty. ${ }^{97}$ Others argue that the Convention does not depart significantly from the traditional doctrine of sovereignty. Thorson argues that, in practice, the principle of limited territorial sovereignty merely attempts to "juxtapose" rights and duties rather than significantly amend or diminish rights associated with territorial sovereignty. Arguably, duties have not been accorded equal weight to rights. The duty not to cause "appreciable" harm is perceived by some as subservient to the rights of territorial sovereignty. ${ }^{98}$

\footnotetext{
${ }^{95}$ McCaffrey (2008), supra note 18 at 354.

${ }^{96}$ Paisley \& Hearns, supra note 7.

${ }^{97}$ General Assembly Adopts Convention on Law of Non-Navigational Uses of International Watercourses, GA Res GA/9248, UN GAOR, 21 May 1997, online: The Water Page <www.thewaterpage.com/UNPressWater.htm> [UN GA Res GA/9248].

${ }^{98}$ The no harm rule is more accurately defined as a duty not to cause appreciable harm and even then the consequence may merely be through compensation. Thorson, supra note 7 at 497-498. See also Joseph W Dellapenna, "The Customary International Law of Transboundary Fresh Waters" (2001) 1 Int'1 J Global Envt'l Issues 264 [Dellapenna]. However, see McCaffrey (2007), supra note 5 at 445 for his assessment
} 
Furthermore, Thorson notes that state reaction to the UN Watercourse Convention is evidence that the entrenchment of territorial sovereignty continues to dominate state objectives and dictate state actions regarding international watercourses.

... that the responses to the 1997 UN Convention, as well as the State treaty practice [in the Himalayas], split so clearly along lower riparian versus upper riparian lines is meaningful. It evinces a strong underlying current of territorial sovereignty and territorial integrity. No State that has within it valuable natural resources wants to subsume its liberty to act according to its best interest of any other State that may be affected. ... and, in this way, territorial sovereignty remains the dominant limiting factor in defining the scope of international water law. ${ }^{99}$

Thorson concludes that while international watercourse law provides for limited territorial sovereignty, "the core concept of territorial sovereignty remains influential and dominant in defining the parameters of international water law." 100

Moreover, the doctrine of sovereignty remains paramount to the extent that sovereign status is required in order to access international water law. Indigenous peoples who lack sovereign status cannot access the equitable principles codified in the Convention. While McCaffrey has suggested that the UN Watercourse Convention and state practice do not support the notion of sovereignty over shared water, from an Indigenous perspective, the doctrine of sovereignty continues to dictate who may make a claim to a legitimate interest or right to the shared water in international negotiations.

\subsubsection{State Agreements and The Mutual Gains Approach}

The UN Watercourse Convention has never been ratified. The legal discourse regarding international custom centres on the analysis of existing bilateral and

that the no harm rule "works in tandem with the principle of equitable utilization" and that it is a "necessary and integral part of the equitable utilization process".

${ }^{99}$ Thorson, ibid at 513.

${ }^{100}$ Ibid at 494. 
multilateral state agreements regarding transboundary watercourses. ${ }^{101}$ Legal scholars participating in the GEF Global Transboundary International Waters Research Initiative ${ }^{102}$ observe that the growing number of transboundary river agreements is indicative of a growing trend towards cooperation among states. ${ }^{103}$ Regardless of any sense of legal obligation, states are increasingly recognizing the mutual benefits that can be derived through collaboration. The discourse regarding state negotiations emphasizes a "mutual gains approach" which focuses on the "reciprocal sharing of benefits" and "mutual gain through cooperative development of water resources." ${ }^{104}$ Grzybowski et al. notes that the documented trend towards collaborative approaches to river agreements may constitute "a shift away from [the] limiting impacts on sovereignty". ${ }^{105}$

Paisley identifies "the principle of equitable sharing of downstream benefits"106 as signaling a new era of cooperation and reciprocity in transboundary law. According to Paisley,

There are a growing number of international agreements which provide for the return, either in kind or in monetary form, of a share of the benefits received in a state or states as a result of acts done in another state or states. $^{107}$

Similarly Grzybowski et al. advocate a "mutual gains approach" to negotiating international watercourse agreements:

Beyond customary international legal obligations lie treaties and other agreements that are negotiated between states in an effort to address

\footnotetext{
${ }^{101}$ Paisley \& Hearns, supra note 7.

102 GEF Global Transboundary International Waters Research Initiative is operated with support from the Global Environmental Facility and the United Nations Development Program. GEF Global Transboundary International Waters Research Initiative, "Good Practices and Portfolio Learning in GEF Transboundary and Marine Legal and Institutional Frameworks" online: IW Learn 〈http://governance-iwlearn.org/“>

${ }^{103}$ Paisley \& Hearns, supra note 7.

${ }^{104}$ Grzybowski et al, supra note 6 at 143 and 144.

105 Ibid at 143.

${ }^{106}$ Paisley, supra note 71 at 281.

107 Ibid at 288.
} 
particular watercourse management issues, to clarify how customary obligations will be met, and in some cases to jointly develop opportunities that neither state could fully capitalize on if acting independently. ${ }^{108}$

Grzybowski et al. argue that the opportunities presented through a mutual gains approach provide powerful incentives for cooperation over transboundary watercourses. ${ }^{109}$ The authors assert that, "[t]he focus of negotiation can shift away from limiting impacts on sovereignty, to planning and devising ways and means of maximizing benefits." ${ }^{110}$ States are willing to consider joint investments and cooperation on development projects that will provide benefits that neither state could achieve acting alone. Incentives help counteract the strong tendency states have towards protecting their independence and sovereignty. ${ }^{11}$

However, from an Indigenous perspective, this perceived tendency by states to move away from the entrenchment of the doctrine of sovereignty is largely illusory. The primacy of state interests remains central to the legal discourse and the principles that guide transboundary water law continue to be derived from the agreements between sovereigns. Indigenous peoples, as non-state actors, are excluded from these sovereign contracts. As a result, they are also excluded from contributing to the development of customary international water law.

\subsubsection{The Sovereign Contract in Transboundary Water Law ${ }^{112}$}

The UN Watercourse Convention is intended as a mechanism to govern the economic and political relationships between sovereign states. Likewise, customary

\footnotetext{
${ }^{108}$ Grzybowski et al, supra note 6 at 143.

109 Ibid.

${ }^{110} \mathrm{Ibid}$

${ }^{111} \mathrm{Ibid}$

${ }^{112}$ The phrase "sovereign contract" is an allusion to classical social contract theory. For a critique of social contract theory from a critical race theory perspective, see Charles W Mills, The Racial Contract, $2^{\text {nd }}$ ed (London: Cornell University Press, 1997) [Mills].
} 
international water law has developed as a reflection of the principles that have emerged from state agreements and presumes that sovereign states, existing as a 'community of sovereigns', are the rightful owners and beneficiaries of transboundary watercourses. The doctrine of sovereignty is firmly entrenched in the legal discourse. While the trend towards cooperation through "mutual sharing of benefits" has been characterized as "a shift away from limiting impacts on sovereignty" ${ }^{\prime 13}$, this is misleading given that sovereign interests dictate the content of regional agreements. The "mutual benefits" gained through cooperation reflect the maximization and preservation of primarily economic state-interests with little regard paid to the impact of such developments upon Indigenous peoples. State interests such as economic development, optimal utilization and the preservation of state sovereignty continue to dominate the discourse of international water law. The reliance upon state bilateral and multilateral agreements as the sole source of international water law principles perpetuates the dominance of state interests over Indigenous people's interests.

From a Critical Race Theory analysis, it is not transboundary water law that is unjust but rather the injustice lies in the fact that it is limited in its application to a community of sovereigns. The equitable utilization and the no-harm principles, as well as the notion of equitable sharing of benefits, appeal to equity, reciprocity, cooperation, fairness and reasonableness. Together they represent an attempt to strike a reasonable middle ground to guide sovereign relations and resonate with the notion of "sovereign equality."114 McCaffrey considers Justice Oliver Wendell Holmes comments regarding the philosophical underpinnings of the equitable utilization rule and states:

\footnotetext{
${ }^{113}$ Grzybowski et al, supra note 6 at 143.

${ }^{114}$ UN Watercourse Convention, supra note 15 at Art 8.1.
} 
A river is a "treasure" that "offers a necessity of life." Therefore, when it flows through more than one jurisdiction, it "must be rationed among those who have power over it." It would be intolerable for the upstream state to cut off all the power from the downstream state, or for the latter to require the former to "give up its power altogether." Thus Holmes effectively rejects both the absolute territorial sovereignty and the absolute territorial integrity theories. He recognizes that "both states have real and substantial interests" and that these interests "must be reconciled as best they may," rather than simply declaring one state the absolute winner and the other the absolute loser. The object of this process of reconciliation "always is to secure an equitable apportionment". 115

An appeal to ethics is at the heart of international water law. Yet, the UN Watercourse Convention fails to apply equity beyond the dominant social contract of state-to-state relations. ${ }^{116}$ If it were "intolerable" for an upstream state to cut off a downstream state, why is it not equally unjust for an upstream "peoples" to cut off a downstream "peoples"? The equity aspired to within international water law remains constrained by the sovereign contract.

It is misleading to engage in the discourse regarding equitable utilization, no harm rule and benefits sharing without also acknowledging that Indigenous peoples are excluded from the international community of sovereigns to which they apply. For Indigenous peoples, transboundary water law remains inaccessible because of the enduring impacts of their unilateral exclusion from the sovereign community during the height of colonialism. The marginalization of Indigenous interests in transboundary rivers cannot be justified simply by asserting that Indigenous peoples' interests should be subordinate to state interests and addressed as domestic or local issues. Any suggestion that states will or do represent Indigenous peoples' interests in the governance of transboundary rivers fails to fully appreciate the oppressive reality of colonialism

\footnotetext{
${ }^{115}$ McCaffrey (2007), supra note 5 at 386.

116 See generally Mills, supra note 112.
} 
throughout the world. Furthermore, Indigenous peoples' rights have been repeatedly affirmed within international law and can no longer be dismissed as a purely domestic issue. Chief Justice of the Supreme Court of Canada, Beverley McLachlin noted in 2002 shortly after being appointed to her position as head of the Supreme Court of Canada, "Whether we like it or not, aboriginal rights are an international matter.",117

The above section has examined the relationship between international water law and sovereignty. The remainder of this chapter locates Indigenous peoples within the legal discourse regarding the international law of transboundary watercourses and within the context of two transboundary rivers.

\subsection{Locating Indigenous Peoples in International Water Law}

Despite the prominence of Indigenous rights in international law, a review of international water law and discourse reveals that there are few references to Indigenous peoples in any context. For example, there are no references to Indigenous issues in the index of McCaffrey's, The Law of International Watercourses, $2^{\text {nd }}$ ed. (2007), the preeminent textbook on international water law. ${ }^{118}$ Indigenous peoples and issues are also absent from the Working Group that negotiated the UN Watercourse Convention as well as from state agreements concerning transboundary rivers. ${ }^{119}$ In this section, I adopt a critical Indigenous lens to deconstruct the UN Watercourse Convention and the related legal discourse and consider the limitations of relying upon sovereignty to define rights and duties in a transboundary context.

\footnotetext{
117 Taiaiake Alfred, Wasáse: Indigenous Pathways of Action and Freedom (North York: Broadview Press, 2005) at 136 [Alfred (2005 Wasáse)].

${ }_{118}$ McCaffrey (2007), supra note 5.

${ }^{119}$ Ibid at 359. The Working Group was open to all UN member states as well as states that were members of specialized agencies.
} 


\subsubsection{UN Watercourse Convention}

The UN Watercourse Convention makes no express reference to Indigenous

peoples or issues although a few sections do encourage states to consider adverse impacts on human populations and human needs. For examples, Article 6 lists several factors that are relevant to the determination of what constitutes "equitable and reasonable utilization" of transboundary watercourse.

Article 6 Factors relevant to equitable and reasonable utilization

1. Utilization of an international watercourse in an equitable and reasonable manner within the meaning of article 5 requires taking into account all relevant factors and circumstances, including:

a. Geographic, hydrographic, hydrological, climatic, ecological and other factors of a natural character;

b. The social and economic needs of the watercourse States concerned;

c. The population dependent on the watercourse in each watercourse State;

d. The effects of the use or uses of the watercourses in one watercourse State on other watercourse States;

e. Existing and potential uses of the watercourse;

f. Conservation, protection, development and economy of use of the water resources of the watercourse and the costs of measure taken to that effect;

g. The availability of alternatives, of comparable value, to a particular planned or existing use.

3. The weight to be given to each factor is to be determined by its importance in comparison with that of other relevant factors. In determining what is reasonable and equitable use, all relevant factors are to be considered together and a conclusion reached on the basis of the whole. ${ }^{120}$

Presumably, Indigenous interests are subsumed by subsection (c) and are weighed equally against all other factors including state interests. However, McIntyre notes that

${ }^{120}$ UN Watercourse Convention, supra note 15 at Art 6 [emphasis added]. 
the International Law Commission's commentary on the draft articles states that "the concept of dependence referred to in Article 6(1)(c) encompasses the size of the population dependent on the water course, as well as the degree of its dependence." ${ }^{121}$ It is unclear how this provision would apply in regions where Indigenous populations are minority populations or how much weight would be accorded to Indigenous peoples' interests in the face of other enumerated factors such as the needs of the states concerned. McIntyre does note that state practice indicates that the use of water for certain basic needs like drinking, domestic purposes, and sanitation are generally accorded priority. ${ }^{122}$ However, it is not clear how this applies to resolve conflicts between Indigenous peoples needs for drinking water versus states' needs for drinking water.

Article 10 makes reference to "vital human needs" as deserving of "special regard".

\section{Article 10 Relationship between different kinds of uses}

1. In the absence of agreement or custom to the contrary, no use of an international watercourse enjoys inherent priority over other uses.

2. In the event of a conflict between uses of an international watercourse, it shall be resolved with reference to article 5 and 7 , with special regard being given to the requirements of vital human needs. ${ }^{123}$

Notably, this recognition of "vital human needs" is not triggered unless there is a conflict regarding the uses of a watercourse. In other words, human rights are not an issue in those circumstances where states agree on the development plans.

As set out above, Article 5 refers to the principle of equitable and reasonable utilization while Article 7 refers to the no-harm rule. Article 7 expressly provides that there are some circumstances where it would be appropriate for harm to be addressed

\footnotetext{
${ }^{121}$ McIntyre, supra note 61 at 160.

${ }^{122}$ Ibid at 161. McIntyre also cites the conclusions of the Irrigation Commission of India in 1972 that, “... domestic requirements may be given highest priority". Ibid at 162.

${ }^{123}$ UN Watercourse Convention, supra note 15 at Art 10 [emphasis added].
} 
through compensation. While never expressly mentioning Indigenous peoples, the Convention guidelines may be interpreted as stating that (i) "harm" suffered by Indigenous peoples under a transboundary agreement should be weighed against several factors including state economic needs; and (ii) that there may be situations where transboundary harm suffered by Indigenous peoples could be reasonably addressed by having the state which caused the harm pay compensation to the state in which the Indigenous peoples live. Only member states can access the dispute resolution process set out under Article 33. Presumably, it is up to states to seek compensation from other states for transboundary harm caused to Indigenous populations, either through agreement or through the dispute resolution process.

Non-state actors are entitled to seek compensation from another state for transboundary harm under Article 32.

\section{Article 32 Non-discrimination}

Unless, the watercourse States concerned have agreed otherwise for the protection of the interests of persons, natural or juridical, who have suffered or are under a serious threat of suffering significant transboundary harm as a result of activities related to an international watercourse, a watercourse State shall not discriminate on the basis of nationality or residence or place where the injury occurred, in granting to such persons, in accordance with its legal system, access to judicial or other procedures, or a right to claim compensation or other relief in respect of significant harm caused by such activities carried on in its territory. ${ }^{124}$

Under this provision, states are prohibited from discriminating against individuals from neighbouring states in allowing them access to the domestic legal system to assert their rights "to claim compensation or other relief" with respect to the transboundary harm. However, Bourquain observes that the effect of this provision is to create a procedural right only to access courts that may or may not recognize the individual or collective

\footnotetext{
${ }^{124}$ UN Watercourse Convention, supra note 15 at Art 32.
} 
rights of Indigenous peoples. It does not provide for any substantive rights for non-state actors. $^{125}$

The Convention does not expressly mention Indigenous peoples or interests and does not ensure water security for non-state actors. This is not surprising given that the Convention reflects the international custom found in bilateral and multilateral state agreements.

\subsubsection{State Agreements and The Mutual Gains Approach}

The mutual gains approach to transboundary agreements holds that two or more states can achieve greater benefit through cooperation and joint development of shared water than by further entrenchment of absolute territorial sovereignty. However, the mutual gains approach is largely premised upon maximizing economic interests through state agreements and offers no protection to Indigenous peoples. Grzybowski et al., note only one example of states' voluntarily invoking the human right to access to water.

Upon reviewing the case example of the Senegal River Basin, Grzybowski et al. note:

It also contains the following innovative provision, one of a number of progressive features of the agreement: "The guiding principles of any distribution of the River's water will guarantee to the populations of the riparian States the full enjoyment of the resources, with respect for the safety of the people and the works, as well as the basic human right to water, in the perspective of sustainable development." 126

According to the authors, this is the sole example of states voluntarily recognizing human rights in transboundary water governance. Even if human rights or Indigenous peoples were voluntarily added to a bilateral agreement, states remain the sole parties to such

\footnotetext{
${ }^{125}$ Knut Bourquain, Freshwater Access From a Human Rights Perspective: A Challenge to International Water and Human Rights Law (Leiden: Martinus Nijhoff Publishers, 2008) at 33.

${ }^{126}$ Grzybowski et al, supra note 6 at 153 .
} 
agreements and would be required to implement and enforce such provisions on behalf of Indigenous peoples.

The mutual gains approach to transboundary negotiations illustrates the bias towards states' economic interests. It is dominated by the assumption that economic gain and collaborative resource development are the best incentives for state cooperation. However, in this framework, Indigenous peoples interests are marginalized as costs of development. For example, Grzybowski et al. cites Sanderson's analysis of the inherent success of the Columbia River Treaty between Canada and the United States which allows for a sharing of downstream benefits in return for upstream development:

The great attraction of this approach was and is that it focuses on the gross benefits and eliminates the need for each country to calculate net benefits. It recognizes that determining what the net benefits and costs of a particular project might be in a way that is acceptable to both countries will often be impossible. The wisdom of finessing the need for the parties to agree on valuing intangible attributes such as species at risk or reconciliation with First Nations is amply demonstrated by the difficulty the entities had in agreeing to the quantification of the CE [Canadian Entitlement] spelled out in the Treaty. By allowing each party to assess its own benefits and costs, the Treaty provides a solution which recognizes this limitation and leaves both countries to seize opportunities that make them better off than they would have otherwise been according to their own values and thus in a position to enthusiastically support whatever initiative is being undertaken. ${ }^{127}$

Indigenous peoples are mentioned solely within the context of states' inability to quantify

a "reconciliation with First Nations"; such reconciliation is presumably necessitated by development projects that adversely impact Indigenous peoples' territories. In this context, "reconciliation with First Nations" is listed as a potential cost of resource development (along with "species at risk"), which is a challenging cost to quantify.

\footnotetext{
${ }^{127}$ Chris Sanderson, Paper delivered to the Transboundary River Governance in the Face of Uncertainty: The Columbia River Treaty, 2014: The Columbia River Treaty After 200416 (2 April 2009), excerpt reprinted in Grzybowski et al., supra note 6 at 150 [emphasis added].
} 
However, the mutual gains approach encourages states to overcome these costs by sharing benefits that they would not be able to achieve if acting independently, to maximize profits and to "reap benefits from the development". In this context, Indigenous peoples are referenced solely in terms of a cost of development to be included in the overall cost-benefits analysis. It further suggests that the costs of the "reconciliation with First Nations", while difficult to quantify, can be successfully managed if states work together to maximize profits.

Taking the UN Watercourse Convention and state agreements together, one must ask whether, under current international water law principles, it would be acceptable for one state to receive a portion of downstream benefits as compensation for action that constitutes a violation of the internationally affirmed rights of Indigenous peoples? While presumably the answer must be no, the current Convention and discourse do not acknowledge the internationally protected status of Indigenous rights and do not provide any mechanism for ensuring that States are not complicit in undermining UNDRIP or international human rights law generally. Even more progressive river governance approaches aimed at integrated basin-wide participatory processes have a tendency to marginalize the rights of Indigenous peoples by placing their interests on equal footing with industry and other non-governmental stakeholders.

\subsubsection{Integrated Watershed Approach}

In stark contrast to international water law, emerging global water governance strategies promote a participatory approach to decision-making. Distilled from principles first articulated in the Rio Declaration, international agencies such as the World Bank, Global Environmental Facility, Global Water Partnership, Environmental NGOs, 
international water practitioners and scholars advocate multi-stakeholder, cross-sector governance and participatory decision-making. ${ }^{128}$ One of the most popular approaches is Integrated Water Resources Management (IWRM), which is defined by the Global Water Partnership as follows:

[It] is a process which promotes the coordinated development and management of water, land and related resources in order to maximize economic and social welfare in an equitable manner without compromising the sustainability of vital ecosystems and the environment. ${ }^{129}$

This approach to governance recognizes "the fundamentally interconnected nature of hydrological resources" ${ }^{130}$ and promotes holistic management of water. Most notably, the cornerstone of this approach is multi-stakeholder governance and public participation. These principles of governance are in stark contrast to international water law's emphasis on sovereign authority and centralized decision-making. However, even within this framework, practitioners often neglect to recognize the international rights of Indigenous peoples. Indigenous peoples are often characterized as having equal footing with "other stakeholders" such as non-profit organizations or industry thereby undermining their collective rights in international law.

For example, the International Joint Commission, which manages transboundary water issues between Canada and the United States, has embraced the International Watersheds Initiative (IWI) which, "promotes an integrated, ecosystem approach to issues arising in transboundary waters through enhanced local participation and

\footnotetext{
${ }^{128}$ Report of the United Nations Conference on Environment and Development (Rio de Janeiro, 3-14 1992) Annex I Rio Declaration of Environment and Development, 3-14 June 1992, GA A/CONF.151/26 (Vol. I) [Rio Declaration]; "What is IWRM?" online: Global Water Partnership <http://www.gwp.org/en/TheChallenge/What-is-IWRM/> [IWRM].

${ }^{129}$ IWRM, ibid.

${ }^{130}$ IWRM, ibid.
} 
strengthened local capacity." "131 However, a review of the IJC's Third Report to Governments entitled, The International Watersheds Initiative: Implementing a New

Paradigm for Transboundary Basins (2009), reveals that Indigenous peoples are granted only a peripheral status within this governance model. ${ }^{132}$ The only reference to Indigenous peoples in the Report is found in the IJC's Key Findings:

The watershed approach is changing the way the IJC does business. Implementing a watershed approach along the international border entails more than just a change in emphasis and tone. It is a paradigm shift that has the potential to transform how our two countries view and manage transboundary waters. The IWI experience has reinforced a recognition of the complex interplay of economic, sociological and environmental factors that affect the quantity and quality of our shared waters. Dealing effectively with these complex interrationships will require new ways of sharing information and data, new technologies, and a renewed commitment to involve and engage local citizens, Native Americans, First Nations, private sector, academia, provinces, states, and federal agencies for a truly integrated watershed approach. ${ }^{133}$

The IJC makes only passing reference to Indigenous peoples as participants in transboundary river governance and only in the same context as other 'stakeholders' such as the private sector and academia. The effect is to marginalize and undermine the affirmed rights of Indigenous peoples in international law.

Furthermore, the Global Water Partnership neglects to even mention Indigenous peoples as stakeholders in its Strategy 2009-2013:

It is well understood that managing water resources in an integrated way is everybody's business and that a range of 'social actors' from different sectors of society and with different economic interests must be involved. As a multi-stakeholder partnership that includes government agencies, private companies, non-governmental agencies, professional organizations,

\footnotetext{
${ }^{131}$ International Joint Commission, "International Watersheds Initiative: Mandate”, online: International Joint Commission <http://www.ijc.org/conseil_board/watershed/en/watershed_mandate_mandat.htm>.

${ }^{132}$ International Joint Commission, International Watersheds Initiatives: Implementing a New Paradigm for Transboundary Basins - Third Report to Governments on the International Watersheds Initiative (Canada \& United States: International Joint Commission, 2009), online: International Joint Commission $<$ http://www.ijc.org/php/publications/pdf/ID1627.pdf $>$.

${ }^{133}$ Ibid at 16 [emphasis added].
} 
gender and youth groups, and bi- and mulit-level development agencies among others, the GWP network is uniquely placed to draw everyone together for dialogue and action. ${ }^{134}$

Given the GWP's stated mandate to 'empower, convene and connect stakeholders' by establishing inclusive platforms for dialogue, the failure to expressly acknowledge Indigenous peoples in this context is striking. ${ }^{135}$ While these initiatives towards integrated, participatory and decentralized decision-making are important milestones in transboundary governance, Indigenous peoples' rights are marginalized within the discourse.

Despite an almost complete absence of representation of Indigenous interests in international water law, Indigenous peoples are the most vulnerable to state decisionmaking regarding transboundary rivers and may also be a formidable source of opposition and conflict with respect to state-initiated development. The next section considers some of the geopolitical complexities surrounding transboundary rivers and locates Indigenous peoples' interests within the context of two transboundary rivers.

\subsection{Case Studies: Indigenous Peoples' Interests in Two Transboundary Rivers}

This section considers Indigenous peoples' interests in two transboundary rivers: the Columbia River shared by Canada and the United States, and the TsangpoBrahmaputra River, originating in the Tibet Autonomous Region and traveling through China, India, Bhutan and Bangladesh. The former represents an example of successful mutual cooperation and stable bilateral relations between states and involves relatively

\footnotetext{
${ }^{134}$ Global Water Partnership, Strategy 2009-2013 (2009), online: Global Water Partnership <http://www.gwp.org/Global/About\%20GWP/Strategic\%20documents/GWP_Strategy_2009-

2013_final.pdf > [Global Water Partnership (2009)]. Also see page 9 and page 16 regarding the Strategic Goals 2009-2013 Outcome 3b, which states, "Stakeholders, including governments, finance and planning ministries, NGOs, the private sector and youth, have better access to relevant and practical knowledge, and more capacity to share that knowledge."

${ }^{135}$ Ibid at 5.
} 
empowered Indigenous peoples with established legal rights. The latter is the site of geopolitical instability involving two rising regional superpowers and politically vulnerable Indigenous populations. Both regions demonstrate the urgent need for a new international water law framework that acknowledges and integrates international Indigenous peoples' rights and offers mechanisms for protecting those rights.

These two case studies have been included for two purposes: (1) to locate Indigenous peoples and interests within transboundary rivers, and (2) to demonstrate how the requirement of sovereign status in international water law not only fails to protect Indigenous rights but may undermine peace in the region by exacerbating tensions between states and Indigenous peoples where sovereign jurisdiction is in dispute.

\subsubsection{Columbia River (North America)}

... the Columbia River does not flow, it is operated. ${ }^{136}$

The 2,000 kilometre long Columbia River travels from the Columbia Lake in the East Kootenay region of British Columbia (BC), Canada, crosses the border into the United States (US), and passes through Washington and Oregon before flowing into the Pacific Ocean. ${ }^{137}$ (See map of Columbia River Basin at Figure 1.) With over 400 dams throughout the Columbia, including 13 on its main stem, it is the most hydroelectrically developed river system in the world. ${ }^{138}$ The Grand Coulee Dam in particular is the

\footnotetext{
${ }^{136}$ Blaine Harden, A River Lost: The Life and Death of the Columbia (New York: WW Norton \& Company, 1996) as cited in Don Gayton, "Ghost River: The Columbia" (2001) 1:2 BC Journal of Ecosystems and Management 1 at 3 [Gayton].

${ }^{137}$ Alice Cohen, Leah Malkinson \& Jennifer Archer, "The Columbia River Treaty: A Look at Evolving Rights \& Interests in the Negotiation of a Transboundary River Treaty" (2005) [unpublished paper, UBC Faculty of Law] at 2.

${ }^{138}$ Ibid at 3.
} 
largest dam in the United States and one of the largest in the world. ${ }^{139}$ The US Pacific Northwest obtains roughly $65 \%$ of its power needs from Columbia River dams, ${ }^{140}$ while BC obtains approximately $50 \%$ of its power from dams located in the Canadian portion of the Columbia River. ${ }^{141}$

The Columbia River was once the greatest salmon producer in the world, ${ }^{142}$ supporting between 7 and 30 million salmon, and upwards of 500,000 salmon in the Canadian portion of the basin alone. ${ }^{143}$ Failure to construct fish passage facilities on the Grand Coulee Dam and the Chief Joseph Dam have resulted in the complete elimination of anadromous salmon from the Canadian Columbia River Basin. ${ }^{144}$ In the Columbia River Basin overall, some $55 \%$ of the original extent of salmon and steelhead habitat has been lost due to dam construction. ${ }^{145}$ Despite these losses, the Columbia River is often cited as a success story as it is the subject of a progressive bilateral state agreement.

\section{a) The Columbia River Treaty}

The Columbia River Treaty (“CRT”) signed by the US and Canada in 1961 is often cited as a model of cooperative transboundary water management, in which the interests

\footnotetext{
${ }^{139}$ L Ortolano, K Cushing \& Contributing Authors, Grand Coulee Dam and the Columbia Basin Project (Case study report prepared as an input to the World Commission on Dams, Cape Town, 2000), online: International Research Center on Environment and Development (CIRED), <http://www.centrecired.fr/IMG/pdf/F9_GranCouleeDam.pdf> [Ortolano et al].

${ }^{140}$ Northwest Power and Conservation Council, "Regional Power System", online: Northwest Power and Conservation Council <http://www.nwcouncil.org/library/2004/2004-16/power.htm>.

${ }^{141}$ Heather C Davidson \& Richard K Paisley "The Columbia River Basin: Issues \& Driving Forces within the Columbia River Basin with the Potential to Affect Future Transboundary Water Management" (March 2009), online: Canadian Columbia River Forum <http://www.ccrf.ca/assets/docs/pdf/issues-driving-forcesccrf-final-march-2009.pdf $>$ at 8 [Davidson \& Paisley].

142 Gayton, supra note 136 at 2.

143 Ortolano et al, supra note 139.

${ }^{144}$ Gayton, supra note 136 at 3-4.

${ }^{145}$ Northwest Power Planning and Conservation Council, "Map of the Columbia River Basin", online: Northwest Power Planning and Conservation Council [http://www.nwcouncil.org/library/2004/200416/map.htm].
} 
of both parties are successfully incorporated into a complex bilateral agreement. ${ }^{146}$ The US benefited from increased protection from flooding as well as increased power production. Canada was entitled to receive $50 \%$ of the financial benefits that were realized by the US in return for building three dams on the Columbia main stem. ${ }^{147}$ In 1964, BC received a one-time payment of US \$64 million in return for the projected flood control benefits of Canadian storage over the 60-year lifetime of the CRT. In 1964, $\mathrm{BC}$, as owner of the benefits, opted to sell the first 30 years of benefits for a lump sum payment of US \$254 million in order to finance the construction of the Canadian dams. ${ }^{148}$ While there is no official expiry date for the CRT, the power part of the agreement can be terminated or renegotiated beginning in 2024, if either party serves notice of the intent to negotiate ten years prior (in 2014).

The Columbia River Treaty is repeatedly held up as a model of successful cooperation and "mutual gains" in the governance of an international watercourse. ${ }^{149}$ However, the CRT dams and previous hydroelectric developments along the Columbia have had devastating impacts upon the Indigenous peoples in the region. ${ }^{150}$

\footnotetext{
${ }^{146}$ Grzybowski et al, supra note 6 at 149-151; Stoeckel, supra note 74 at 85 . See generally, Glen Hearns, "The Columbia River Treaty: A Synopsis of Structure, Content, and Operations" (Prepared for the Canadian Columbia River Forum, September 2008), online: Canadian Columbia River Forum <http://www.ccrf.ca/assets/docs/pdf/columbia-river-treaty-synopsis-ccrf-final-sept-2008.pdf>; Davidson \& Paisley, supra note 141.

147 Stoeckel, supra note 74.

148 Jonathan A Lesser, "Resale of the Columbia River Treat Downstream Power Benefits: One Road From Here to There" (1990) 30 Nat Resources J 610 at 614.

149 See Grzybowski et al, supra note 6; Paisley, supra note 71; Stoeckel, supra note 74.

${ }^{150}$ Davidson \& Paisley, supra note 141 at 14.
} 


\section{b) Indigenous Peoples in the Columbia River Basin}

Indigenous peoples have lived within the Columbia River Basin for more than

10,000 years. ${ }^{151}$ Within the Canadian portion of the Columbia River Basin, the Ktunaxa,

Okanagan and Secwepmec (Shuswap) Nations are the three main tribal groups whose

traditional territories extend throughout the watershed. ${ }^{152}$ Within the US portion of the

Columbia River Basin, 14 tribal groups are recognized today: ${ }^{153}$

Burns Paiute Tribe

Coeur d'Alene Tribe

Confederated Salish and Kootenai Tribes of the Flathead Reservation

Confederated Tribes and Bands of the Yakama Nation

Confederated Tribes of the Coliville Reservation

Confederated Tribes of the Grand Ronde Community of Oregon

Confederated Tribes of the Umatilla Indian Reservation

Confederated Tribes of the Warm Springs Reservation of Orgegon

Kalispel Tribe of Indians

Kootenai Tribe of Idaho

Nez Perce Tribe

Shoshone Bannock Tribes of the Fort Hall Reservation

Shoshone-Paiute Tribes of the Duck Valley Reservation

Spokane Tribe of Indians

Some of the US tribal groups were historically united with and related to Canadian tribes

prior to the establishment of an international border between Canada and the US. ${ }^{154}$

\footnotetext{
${ }^{151}$ The earliest archaeological evidence of human habitation in the Columbia River Basin dates to 10,000 years ago. Centre for Columbia River History. See Center for Columbia River History, "Columbia River", online: Center for Columbia River History ‘〈http://www.ccrh.org/river/history.htm\#indigenous〉. Oral histories of the Ktunaxa Nation note that the Ktunaxa have used and occupied their territory for over 12,000 years. See Ktunaxa Nation, "Ktunaxa History Timeline", online: Ktunaxa <http://www.ktunaxa.org/who/timeline.html> [Ktunaxa Nation].

${ }^{152}$ Historically the Sinixt Nation or Arrow Lakes people also inhabited the Basin. However, as their population declined, the Sinixt people were largely assimilated into the Ktunaxa Nation and US Colville tribes, and in 1956 the Federal Government declared the band as 'extinct'. See Sinixt Nation "Keeping the Lakes Way", online: Sinixt Nation <http://sinixt.kics.bc.ca/history.html>.

${ }^{153}$ Northwest Power Planning and Conservation Council, The Northwest Power and Conservation Council's Directory of Columbia River Basin Tribes (2007-5), online Northwest Power and Conservation Council at: http://www.nwcouncil.org/library/2007/2007-5.htm> [Directory].

${ }^{154}$ Ibid at 46 of the Directory, which states, "The international border is a political boundary, and many Canadian First Nation people have relatives in the United States and vice versa. These include, for example, people of the Canadian Okanagan descent who live today on the Colville Reservation, and members of the Ktunaxa/Kinbasket tribe who live on the Salish and Kootenai Reservation in Montana."
} 
For thousands of years, Indigenous peoples in the Columbia Basin have lived in a close interrelationship with the land, obtaining their food, medicines and material needs largely through hunting, fishing and gathering. Salmon played an especially important role in the culture of many First Nations, both as a food source and for spiritual and ceremonial reasons. As noted by members of the Columbia River Treaty tribes:

Salmon and the rivers they use are part of our sense of place. The Creator put us here where the salmon return. We are obliged to remain and to protect this place. Without salmon returning to our rivers and streams, we would cease to be Indian people. ${ }^{155}$

Arguably, it was the construction of the Grand Coulee Dam in 1941 that had the most significant and widespread impact on First Nations in the Columbia River Basin.

Downstream of the dam the fishery was largely destroyed, and upstream it was completely eliminated, as fish passage facilities were not constructed at the dam site. ${ }^{156}$ Thousands of Indigenous peoples were forced to relocate as the loss of salmon meant the loss of an integral part of their diet and culture. ${ }^{157}$

In Canada, First Nations were not even notified of the plans to build the Grand Coulee Dam and the impending loss of their fishery, nor were they compensated for it. ${ }^{158}$ With the closing of the gates at Grand Coulee, Sinixt Nation people who were dependent on Columbia River salmon stocks migrated to live with the Colville and Kootenay tribes

\footnotetext{
${ }^{155}$ Columbia River Inter-Tribal Fisheries Commission, "The Importance of Salmon to the Tribes", online: Columbia River Inter-Tribal Fisheries Commission <http://www.critfc.org/text/salmcult.html>.

${ }_{156}$ Ortolano et al, supra note 139 at xiii \& 74-76.

${ }^{157}$ Ibid at 76.

${ }^{158}$ Fish stocks lost, included Arrow, Slocan, and Whatshan sockeye, Columbia and Windermere Lake sockeye, and numerous stocks of Chinook. See Ortolano et al, supra note 139. See also Canadian Columbia River Inter-Tribal Fisheries Commission, "Letter from Mr. Fred Fortier, Chairperson of the Canadian Columbia River Inter-Tribal Fisheries Commission (CCRIFC) with respect to the IJC's Order of Approval of December 15, 1941, in the matter of the application of the Government of the United States for approval for the construction and operation of the Grand Coulee dam and reservoir" (23 April 2003), online: International Joint Commission <www.ijc.org/rel/boards/ccrifc/request_ccrifc-e.htm> [CCRIFC].
} 
in the US. ${ }^{159}$ The Ktunaxa note that the Federal Government promised to provide them with canned salmon as compensation, but never did. ${ }^{160}$ Indigenous peoples were "disproportionately affected by the loss of the salmon from one of the world's largest salmon producing river systems." 161

First Nations communities suffered the most devastating impacts of hydroelectric development prior to the CRT agreement. However, the CRT exacted further impacts, with the loss of numerous archaeological and burial sites under newly created reservoirs, ${ }^{162}$ and the decline of resident fish populations of importance to First Nations due to dam construction. ${ }^{163}$ First Nations rights and interests were not recognized during the negotiation of the Columbia River Treaty. The dominant values considered in the Treaty negotiations were state interests involving power and flood control, with only cursory consideration to other values. ${ }^{164}$

Indigenous peoples have expressed an enduring and persistent interest in protecting and restoring their Indigenous rights, and in seeing salmon return to the waters of the Columbia River. ${ }^{165}$ In 1993, members of the Ktunaxa, Okanagan and Secwepmec Nations formed the Canadian Columbia River Inter-Tribal Fisheries Commission ("CCRIFC"), for the purpose of considering their options in relation to the loss of the

${ }^{159}$ Ortolano et al, supra note 139 at 74-76.

${ }^{160}$ Ktunaxa Nation, supra note 151.

${ }^{161}$ Stoeckel, supra note 74 at 103.

${ }^{162}$ Davidson \& Paisley, supra note 141 at 14.

${ }^{163}$ See K Ashley et al. "Restoration of kokanee salmon in Kootenay Lake, a large intermontane lake, by controlled seasonal additions of nutrients" in T. Murphy and M. Munawar, eds., Aquatic Restoration in Canada (Leiden, Netherlands: Ecovision World Monogaph Series, Backhuys Publishers, 1999) 127.

${ }^{164}$ Neil Swainson, "The Columbia River Treaty - Where Do We Go From Here" (1986) 26 Nat Resources J 252. See also Nigel Bankes, "Multiple Actors in Canada-US Relations: Environment: Garrison Dam, Columbia River, The IJC, NGOs" (2004) 30 Can-US LJ 117.

165 Andrew Gage with Nigel Bankes, "Submissions by West Coast Environmental Law to the International Joint Commission: In regard to the application of the Canadian Columbia Inter-Tribal Fisheries Commission Concerning the Grand Coulee Dam" (Vancouver: West Coast Environmental Law, October 2005), online, <http://www.wcel.org/resources/publication/submissions-west-coast-environmental-lawinternational-joint-commission-regard $>$ at 8. 
traditional anadromous fishery, as well as the significant damage inflicted on the resident fishery by power operations. ${ }^{166}$ For over a decade the CCRIFC has been working on a strategy to persuade the US to restore salmon runs. ${ }^{167}$ This work culminated in a submission to the International Joint Commission (IJC) ${ }^{168}$ in 2003 in which they requested,

... an Order convening a panel of experts and initiating a public process to identify and assess the damage caused by the Grand Coulee dam and to investigate options for mitigation and compensation and for restoring salmon to the Canadian portion of the Columbia River Basin. ${ }^{169}$

CCRIFC argued that the IJC has the jurisdiction to request such an Order, since there is evidence that the conditions of their 1941 Order related to the approval of the Grand Coulee Dam were never met, especially those which required "the protection and indemnification of interests in British Columbia by reason of damage to the salmon fisheries, culture and economy of First Nations resulting from the construction and operation of the Grand Coulee Dam". ${ }^{170}$

In March and June 2006 the US and Canada governments responded to the IJC's request for comment with letters from the Office of Canadian Affairs of the U.S. State Department and the U.S. Relations Division of Foreign Affairs Canada, respectively. Both governments advised that the IJC did not have jurisdiction to consider the

\footnotetext{
${ }^{166}$ Nigel Bankes, "The Columbia Basin and the Columbia River Treaty: Canadian Perspectives in the 1990s" (Working Paper delivered to Northwest Water Law and Policy Project PO95-4) Northwestern School of Law of Lewis and Clark College (1996) at 102.

${ }^{167}$ Mark Hume, "BC Natives Want Salmon Back in Columbia River: Editorial" The Globe and Mail (2 November 2005).

${ }^{168}$ The International Joint Commission [IJC] was established by the 1909 Boundary Waters Treaty between Canada and the United States to prevent or resolve water disputes along the entire US-Canada border. See Treaty relating to the Boundary Waters and Questions Arising along the Boundary between the United States and Canada, signed at Washington 11 January 1909, entered into force 5 May 1910, online: International Joint Commission 〈http://www.ijc.org/rel/agree/water.html\#text .

${ }^{169}$ CCRIFC, supra note 158.

${ }^{170}$ Ibid at 8 .
} 
CCRIFC's claim. A few months later, the IJC confirmed by letter that the CCRIFC should discuss the issue with Foreign Affairs Canada, as that was the "appropriate" avenue for their claim. ${ }^{171}$

In 2006, the Secwepmec Nation, Okanagan Nation and Ktunaxa Nation formed the Upper Columbian Aquatic Management Partnership with the stated goal: "to conserve and enhance healthy aquatic ecosystems, wild indigenous fish communities, and aboriginal fisheries in the Columbia Basin." ${ }^{172}$ The Partnership is based on the following principles from each Nation.

- Secwepemc: Tknémentem Secwepemcúlecw "Respect the earth and do not waste natural resources in our traditional territory."

- Okanagan: Tel kqoolentsooten swhitzetzxtet ee toomtemtet, ksnpee-eelsmentem, kstxetdentim oothl kskgethlkchiwhentem. The creator has given us our mother, to enjoy, to manage and to protect. Loot penkin koo tdeks ntzespoolawhax. Peentk kstxtdiplantem ee tel toomtem an hchastantet koo kgel yayart, tel arpna oothl tdeswhoois. We will survive and continue to govern our mother and her resources for the good of all for all time.

- Ktunaxa: The universal laws that guide us in our society, particularly in relationship to the land: ... ${ }^{173}$

In the United States, the Columbia River Inter-tribal Fisheries Commission ("CRIFC") represents the Nez Perce Tribe, the Confederated Tribes of the Umatilla Indian Reservation, the Confederated Tribes of the Warm Springs Reservation of Oregon, and the Confederated Tribes and Bands of the Yakama Indian Nation. ${ }^{174}$ The Upper Columbia United Tribes ("UCUT") was formed by the Coeur d'Alene, Kalispel, Kootenai, Spokane and Colville Tribes for the purpose of uniting their resources to

\footnotetext{
${ }^{171}$ International Joint Commission, "Response from the IJC to Mr. Fred Fortier on the request from CCRIFC" (31 October 2006), online: International Joint Commission $\langle$ http://www.ijc.org/en/activities/main_princ.htm\#coulee>

${ }^{172}$ Upper Columbia Aquatic Management Partnership as cited in Davidson \& Paisley, supra note 141 at 11.

${ }^{173}$ Davidson \& Paisley, ibid.

${ }^{174}$ Columbia River Inter-tribal Fisheries Commission, “Columbia River Treaty Tribes”, online: CRITFC <http://www.critfc.org/text/tribes.html>.
} 
protect the tribes on issues regarding the treaty rights, sovereignty, fish, wildlife, habitat, education and ecological development. Indigenous peoples in the US have been active in protecting the Columbia River Basin from transboundary pollution by Canadian industry. In Pakootas v Teck Cominco Metals, Ltd., ${ }^{175}$ members of the Colville Tribe initiated litigation against Canadian mining company in a successful attempt to apply United States environmental legislation against a Canadian company. Justice Gould concluded:

Teck owns and operates a lead-zinc smelter ("Trail Smelter") in Trail, British Columbia.[5] Between 1906 and 1995, Teck generated and disposed of hazardous materials, in both liquid and solid form, into the Columbia River. These wastes, known as "slag," include the heavy metals arsenic, cadmium, copper, mercury, lead, and zinc, as well as other unspecified hazardous materials. Before mid-1995, the Trail Smelter discharged up to 145,000 tons of slag annually into the Columbia River. ${ }^{176}$

In considering the extraterritorial application of the U.S. Comprehensive Environmental Response, Compensation, and Liability Act (CERCLA), the court held that, "applying CERCLA here to the release of hazardous substances at the Site is a domestic, rather than an extraterritorial application of CERCLA, even though the original source of the hazardous substances is located in a foreign country.",177

The examples of the CCRIFC's application to the IJC and the Colville tribes litigation against Teck Cominco are illustrative of the sophisticated efforts that Indigenous peoples on both sides of the US-Canada border are bringing to bear in an effort to address and mitigate the transboundary impacts of development upon their rights in the Columbia basin. It is notable however that Indigenous rights and interests within this transboundary basin continue to be framed in terms of domestic issues.

\footnotetext{
${ }^{175}$ Pakootas $v$ Teck Cominco Metals, Ltd, (2006) 452 F 3d 1066 (US CA $9^{\text {th }}$ Cir).

${ }^{176}$ Ibid at 1069.

${ }^{177}$ Ibid at 1079.
} 


\section{c) Discussion}

In future negotiations over the Columbia River, Canada and the United States are likely to be aligned with respect to hydropower, flood control and the maximization of financial benefits from development through cooperation. While negotiations are likely to be complex given the financial interests involved and the complicating factors of climate change and growing domestic demands, their positions will likely be ideologically aligned. At issue is how to integrate Indigenous peoples' interests, rights and values into the negotiations regarding transboundary development. Davidson \& Paisely summarize Indigenous peoples' interest in future negotiations as follows:

First Nations also seek to minimize the erosion impacts of water and wind on potential archaeological zones; maintain the cultural, aesthetic and ecological context of important cultural resources and spiritual sites; minimize the impact of destructive human behaviour (eg. Traffic) on potential archeological zones, and maximize abundance and diversity of fish and wildlife populations to support First Nations harvesting and associated activities. $^{178}$

Not surprisingly, Indigenous peoples seek to apply Indigenous principles to the governance of the Columbia River basin. Davidson \& Paisely observe, that the Ktunaxa hope that "three values, in particular, will inform water governance in the post-treaty environment: (i) the sacred, life sustaining value of water; (ii) a holistic, ecoystemic view; and (iii) a long-term perspective." 179

From the perspective of current international water law discourse, the cooperation between Canada and the United States regarding development of the Columbia Basin is illustrative of successful state negotiations. The peaceful commitment to mutual gains

${ }^{178}$ Davidson \& Paisley, supra note 141 at 11.

${ }^{179}$ Ibid at $\mathrm{n} 18$. 
through cooperative development is held up as a successful model for transboundary river governance. It is a story of cooperation, reciprocity and mutual gains. ${ }^{180}$

The impact upon Indigenous peoples is downplayed within the context of international law and discourse. While the emergence of domestic legal rights for First Nations peoples in both Canada and the United States will dramatically impact the nature of future negotiations over the Columbia Basin, Indigenous peoples have no recourse within international water law. ${ }^{181}$ The $U N$ Watercourse Convention fails to situate Indigenous peoples, interests and principles within transboundary governance or provide an effective avenue for the assertion of their internationally recognized legal rights. Indigenous peoples' efforts to assert their rights and status within transboundary river development remains defined by domestic policies, domestic laws and is treated as a domestic issue, albeit an extremely complex one.

Moreover, Indigenous rights and interests in the Columbia Basin continue to be characterized as part of the cost of development that is weighed against the benefits of cooperative state development. Historically, Canada and the US have addressed claims by resident Indigenous peoples by considering or providing compensation for past infringements. ${ }^{182}$ The existing ethos of "mutual gains" and "optimal utilization" within the Columbia River Basin begs the question of whether the adverse impacts of future

\footnotetext{
${ }^{180}$ Stoeckel, supra note 74 at $81-82$, states, "[i]t is a story where cooperation was sought between two levels of government in Canada, and between two great nations in order to fully utilize the vast water resources of the Columbia River."

${ }^{181}$ While they could seek remedy in international human rights courts for violations made by their own country, human rights bodies are not equipped to deal with transboundary claims. See Shelton, infra note 593.

${ }^{182}$ In Canada, BC created the Columbia Basin Trust and dedicated some of the profits from the CRT to support the local communities of the Basin. See Columbia Basin Trust Act, RSBC 1996, cC-53.
} 
developments on Indigenous peoples can be simply quantified and characterized as a cost of development. ${ }^{183}$

Indigenous peoples within the Columbia River Basin tell a very different story about the Columbia River. Their livelihoods and culture have been irreparably harmed by past development, with little compensation, and their interests regarding future development are constrained by national policies that subordinate their claims to state interests. While the rights of Indigenous peoples have been affirmed under UNDRIP and other instruments, they currently have no recourse to protect those rights under international water law.

Notwithstanding outstanding aboriginal title and traditional territorial claims, Indigenous peoples within the Columbia River Basin are relatively empowered through the Canadian and American legal systems to pursue their rights to consultation and participatory decision-making. However, Indigenous peoples in other regions of the world are even more vulnerable to state development of transboundary rivers in those regions where they have no recourse to either national or international law.

\footnotetext{
${ }^{183}$ See generally, Stoeckel, supra note 74.
} 


\subsubsection{Yarlung Tsangpo-Brahmaputra River (Asia)}

The mighty Brahmaputra, holy site of the great synthesis, has for untold centuries been propagating the message of unity and harmony. . ${ }^{184}$

\section{Bhupen Hazarika, PhD Assamese singer and lyricist}

The Brahmaputra, the river normally neglected by most writers, is probably the most significant in the present day geopolitical context.

$$
\text { Dr. S.D. Mishra }{ }^{185}
$$

The largest river in Tibet, the Yarlung Tsangpo (Tsangpo) River emerges from the sacred Kailash mountain range in the Himalayas of western Tibet at an elevation of 5300 meters and flows east across the heights of the Tibetan Plateau. ${ }^{186}$ Deep within the jungles and gorges of eastern Tibet, the river arches in a great horseshoe bend (the "Great Bend") and travels north, northeast and then south and southwest into the Indian province of Arunachal Pradesh where it is known as the Dihang or Siang. ${ }^{187}$ (See map of the Tsangpo-Brahmaputra Basin at Figure 2). It then joins the flow of two other TransHimalayan rivers, the Dibang and the Lohit, where it becomes known as the Brahmaputra. The Brahmaputra then passes through the Indian state of Assam before winding south to Bangladesh as the Jamuna River where it joins with the Ganges and the

\footnotetext{
${ }^{184}$ Bhupen Hazarika quoted in Arup Kumar Dutta, The Brahmaputra (India: National Book Trust, 2001) [Dutta]. Translated from the original Assamese text "Mahabahu Brahmaputra, Mahamilanar Tirtha, Shatajug Dhari Ahise Prakashi Samannayar Artha”.

185 Dutta, ibid at xi.

${ }^{186}$ Tashi Tsering, China's Water Politics: In Whose Interest? (MA Thesis in Political Science, Portland State University, 2005) [Unpublished] at 45 [Tsering (2005)]; CSP Ojha \& VP Singh, "Introduction" in Vijay P Singh, Nayan Sharma \& C Shekhar P Ojha, eds, The Brahmaputra Basin Water Resources (London: Kluwer Academic Publishers, 2004) at 2 [Ojha \& Singh] [Singh et al]; BC Upreti, Politics of Himalayan River Waters: An Analysis of River Water Issues of Nepal, India and Bangladesh (New Dehli: Nirala Publications, 1993) [Upreti]. Note that Upreti describes elevation as $5750 \mathrm{~m}$. The river is called by many names including Yarlung Zangbo, Yarlung River (Tibetan) or Yalu Zangbu River or Yarlung Tsangpo and Yarlung Zangbo Jiang.

${ }^{187}$ JN Sarma, “An Overview of the Brahmaputra River System” in Singh et al, ibid, 72 at 73 [Sarma].
} 
Mengha and forms part of the world's largest river delta in the Bay of Bengal. ${ }^{188}$ In total, the Basin drains an area of approximately 651,000 square kilometres and the entire journey is 2880 kilometres. ${ }^{189}$

The Tsangpo-Brahmaputra holds many distinctions within the natural world. The Brahmaputra basin is one of the most ecologically diverse areas in the world. Within Assam alone, there are 51 different forest types and subtypes occurring in the region. ${ }^{190}$ It also holds the distinction of traversing one of the most earthquake-prone regions in the world. ${ }^{191}$ Scientists have concluded that the region around the Brahmaputra crosses the Indian and Eurasian tectonic plates. It is the convergence of these two plates that has resulted in the formation of the Himalayan mountain range. ${ }^{192}$

The Tsangpo is also the highest river in the world as it passes through the Greater Himalayas, averaging $6000 \mathrm{~m}$, before emerging as the Brahmaputra on the plains of Arunachal Pradesh. Only recently surveyed in its entirety, in 1999, the Tsangpo flows through the world's deepest gorge (the "Great Canyon"), estimated to be eight times as steep and three times as deep as the Grand Canyon in Colorado. ${ }^{193}$ At the eastern most point of the river in Tibet, the river flows through the Great Bend before plummeting over $3000 \mathrm{~km}$ in approximately $200 \mathrm{~km}$. Its hydropower potential is unprecedented. The river is also unique in the world for never having been developed. Recently, however, it has become the focus of proposed mega-development projects by two global super

\footnotetext{
${ }^{188}$ Ibid at 73 .

${ }^{189}$ Carmen Revenga et al, Watersheds of the World: Ecological Value and Vulnerability (Washington, D.C.: World Resources Institute \& Worldwatch Institute: 1998) at 2-75; Ojha \& Singh, supra note 186 at 2; Dutta, supra note 184 at 1.

${ }^{190}$ BK Talukdar, "Ecology" in Singh et al, supra note 186, 351 at 352.

${ }^{191}$ Ojha \& Singh, supra note 186 at 7.

192 Amita Sinvhal \& Vipul Prakash, "Seismo-Tectonics and Earthquake Design Parameters" in Singh et al, supra note 186,578 at 585.

${ }^{193}$ Sarma, supra note 187 at 76 . The course of the Brahmaputra was not completely mapped in India till as recently as 1927. It was only in 1999 that the Great Canyon was surveyed.
} 
powers. Both China and India have plans to harness the river to support their burgeoning populations.

Transboundary management of the Tsangpo-Brahmaputra River poses unique challenges to the political actors involved and the world at large. First, the geopolitical relations between China, the Tibetan Government in Exile, and India is rife with unresolved conflict regarding sovereignty, political boundaries and uncooperative water management. In addition, the power dynamics are unique in that there exist not one but two regional powers that are also quickly emerging as the highest consumers of energy and resources in the world. ${ }^{194}$

\section{a) State Interests in the Tsangpo-Brahmaputra River Basin}

There are four states that share the Tsangpo-Brahmaputra Basin: China, India, Bangladesh and Bhutan. While the interests and issues confronting Bangladesh and Bhutan are formidable as vulnerable downstream states, this case study is limited to a consideration of the interests and agendas of the two regional superpowers, China and India as they may impact upon Indigenous peoples in the Basin.

\section{i) China}

All of China's water resources are under stress. ${ }^{195}$ China's river basins are plagued by numerous environmental problems, including unregulated toxic dumping,

194 See generally Jennifer L Turner \& Lü Zhi, "Building a Green Civil Society in China" in The Worldwatch Institute, ed, State of the World 2006: Special Focus: China \& India (Washington, D.C.: World Watch Institute, 2006) 3 [World Watch Institute].

${ }^{195}$ See generally, Zhongguo Shui Weiji, China's Water Crisis trans by Nancy Yang Liu \& Lawrence R Sullivan (Norwalk, CT: EastBridge, 2004) [Weiji]; Hu Kanping with Yu Xiaogang "Bridge Over Troubled Waters: the Role of the News Media in Promoting Public Participation in River Basin Management and Environmental Protection in China" in Jennifer L Turner \& Kenji Otsuka, eds, Promoting Sustainable River Basin Governance: Crafting Japan-US Water Partnerships in China (Chiba, Japan: Institute of Developing Economics: 2005) 125 at 125 and 133 [Turner \& Otsuka]; Christopher Flavin \& Gary Gardner, "China, India and the New World Order" in Worldwatch Institute, ibid at 7 [Flavin \& Gardner]. 
flooding caused by deforestation, severe water shortages, unsustainable river basin management, and aggressive big dam development. ${ }^{196}$ The country currently holds $22 \%$ of the world's population but only $8 \%$ of the global freshwater resources. ${ }^{197}$ In addition, $42 \%$ of China's farmland is located in the semi-arid north that contains only $8 \%$ of the country's freshwater runoff. ${ }^{198}$

China's population is expanding at an extraordinary rate and its growing consumption of resources and demand for energy to fuel economic development is exacting a high toll on the global environment. ${ }^{199}$ Increasingly, China has turned to hydropower to meet this demand. Since 1949, China has built approximately 22,000 of the world's 45,000 large dams. ${ }^{200}$

China continues to demonstrate a "paradigmatic faith" ${ }^{201}$ in large-scale water development projects. The World Commission on Dams published a report in 2000 in which it questioned the utility and desirability of large dams, however China dismissed those findings as biased and impinging on its absolute territorial sovereignty. ${ }^{202}$ China's ethos of big dam development is most aptly exemplified by its construction of the Three Gorges Dam on the Yangtze River, which has displaced millions of people, making it the

\footnotetext{
${ }^{196}$ Kanping \& Xiaogang, ibid; Wang Yahua, "River Governance Structure in China: A Study of Water Quantity/Quality Management Regimes" in Turner \& Otsuka, ibid, 23 at 23 and 25 [Yahua]; Patricia Wouters et al, "The New Development of Water Law in China" (2004) 7 Univ of Denver Water Law Rev 243 at 251.

${ }^{197}$ Flavin \& Gardner, supra note 195 at 7; Yahua, ibid at 23 stated $7 \%$ and $21 \%$ respectively.

198 Yahua, ibid.

${ }^{199}$ See Flavin \& Gardner supra note 195, for a general discussion of China's energy needs. See also Yahua, ibid.

${ }^{200}$ Huw Pohlner, "Chinese dam diplomacy: Leadership and geopolitics in continental Asia" in EastAsia Forum (19 August 2010), online: East Asia Forum < http://www.eastasiaforum.org/2010/08/19/chinesedam-diplomacy-leadership-and-geopolitics-in-continental-asia/ $>$. A large dam is one that is more than 15 metres in height.

${ }^{201}$ Tsering (2005), supra note 186 at 10.

${ }^{202}$ Milton Osborne, River at Risk: The Mekong and the Water Politics of China and Southeast Asia (New South Wales: Lowy Institutes for International Policy, 2004) at 15 [Osborne].
} 
"largest human relocation effort in world history". ${ }^{203}$ Critics of the project have also raised concerns regarding the adverse impact of the dam on local communities, archaeological sites, cultural relics and the environment.

China has recently expressed interest in developing the Great Canyon of the Tsangpo River in the Tibet Autonomous Region to satisfy the nation's demands for water and hydropower. ${ }^{204}$ The power potential available from a hydroelectric plant at the Great Bend would generate 40,000 megawatts, more than twice the electricity produced by the Three Gorges Dam. ${ }^{205}$ There are also reports that China intends to divert water northward to China's arid northwestern provinces of Xinjiang and Gansu (Gobi Desert). There are now reports that China is considering the development of a 38 gigawatt hydropower plant at the Great Bend " that would be more than half as big again as the Three Gorges dam, with a capacity nearly half as large as the UK's national grid."206 Tsering reports that China is also considering another 28 along the Tsangpo. The construction of a mega dams along the Tsangpo represents a direct threat to the Indigenous peoples of eastern Tibet and Arunchal Pradesh as well as the water security of millions of people living downstream in India, Bhutan and Bangladesh. Aside from the

\footnotetext{
203 Tsering (2005), supra note 186 at 34.

${ }^{204}$ The Economist, "Unquenchable Thirst: A growing rivalry between India, Pakistan and China over the region's great rivers may be threatening South Asia's peace" The Economist (19 November 2011), online: The Economist <http://www.economist.com/node/21538687> [The Economist]; Tsering, (2005) supra note 186; Claude Arpi, "Dams on the Brahmaputra," (1 May 2010), online: Claude Arpi Blogspot <http://claudearpi.blogspot.com/2010/05/dams-on-brahmaputra.html > [Arpi (2010)]; Claude Arpi, "Diverting the Brahmaputra: Declaration of War?" Rediff (23 October 2003), online: Rediff <www.rediff.com///news/2003/oct/27spec.html> [Arpi (2003)]; Danielle Mitterand, "Tibet Set to Become Next Flashpoint" TibetNet (14 June 2004), online: Students for a Free Tibet <www.studentsforafreetibet.org/article.php?id=271> [Mitterand].

${ }^{205}$ The Economist, ibid; Tsering (2005), supra note 186; Claude Arpi, "Himalayan Rivers: Geopolitics and Strategic Perspectives" Indian Defence Review (17 February 2011), online: Indian Defence Review <http://www.indiandefencereview.com/geopolitics/Himalayan-Rivers-Geopolitics-and-StrategicPerspectives.html > [Arpi (2011)].

${ }^{206}$ Jonathan Watts, "Chinese engineers propose world's biggest hydro-electric project in Tibet" The Guardian (24 May 2010), online: The Guardian <http://www.guardian.co.uk/environment/2010/may/24/chinese-hydroengineers-propose-tibet-dam>.
} 
spiritual significance of the region to local Indigenous peoples, Arpi notes that the construction of the project will bring immense hardship to the Indigenous people living in the canyon, as they will "be forced to leave their ancestral lands."207 Given that China has typically not acknowledged the rights of Indigenous peoples or consulted with downstream states with respect to engineering projects on transboundary watercourses, there is legitimate cause for concern. ${ }^{208}$

Historically, China has exhibited a pattern of non-cooperation with respect to transboundary rivers and has emphasized its absolute sovereign right to exploit rivers in its territory. China was one of only three countries to vote against the UN Watercourse Convention on the basis that the text did not reflect the absolute territorial sovereignty of a riparian state over the watercourse that flowed through its territory. ${ }^{209}$ China's noncompliance with international norms is illustrated by China's diversion of the Black Irtysh River away from Kazakhstan, which Sievers characterized as a violation of customary international law both "in its conception and in China's dealings with coriparians". ${ }^{210}$ In addition, China's failure to become a member of the Mekong River Commission is often perceived as indicative of China's "isolation policy". 211 China, as a powerful upstream riparian, is likely to maintain its position regarding absolute territorial sovereignty and this, in turn, may undermine transboundary cooperation and regional environmental protection in the region.

\footnotetext{
${ }^{207}$ Arpi (2011), supra note 205. The Economist, supra note 204.

${ }^{208}$ Osborne, supra note 202 at 15; Eric W. Sievers, "Transboundary Jurisdiction and Watercourse Law: China, Kazakhstan and the Irtysh" (2002) 37 Tex Int'1 L J 1 [Sievers].

${ }^{209}$ UN GA Res GA/9248, supra note 97.

${ }^{210}$ Sievers, supra note 208 at 2.

${ }^{211}$ Mikiyasu Nakayama, "China as Basin Country of International Rivers" in Turner \& Otsuka, supra note 195, 6 at 66, online: Institute of Developing Economics <http://www.ide.go.jp/English/Publish/Spot/28.html >. However, others note that China has demonstrated a willingness to participate in other regional development agencies such as the Greater Mekong Sub-region.
} 
ii) India

In India, rivers are sacred. The Brahmaputra received its name as the son of Lord Brahma and it is unique in being the only 'male' river in India. ${ }^{212}$ In addition to its cultural and spiritual significance, India's primary interests in the Brahmaputra include hydropower, flood control, irrigation, navigation and water quality. ${ }^{213}$ Irrigation is currently the dominant use of water in India with $92 \%$ of present usage devoted to agriculture. $^{214}$ The Brahmaputra holds the distinction as holding the greatest potential for India and also being the least developed. ${ }^{215}$ As of 2004 , only about $3 \%$ of the river's potential had been harnessed. India's central challenge is to utilise the hydropower potential of the river and transfer that power to other regions. ${ }^{216}$ In addition, population growth is greater in northeast India than in the rest of the country and will be home to an estimated 80 million people by $2050 .^{217}$ The development of the Brahmaputra is particularly important given that these northeastern provinces have suffered from lack of development and social unrest. ${ }^{218}$ It is generally believed that tapping the Brahmaputra's potential holds the greatest potential for invigorating and sustaining these depressed regions of India.

The Northeastern regions of India are particularly vulnerable to China's water projects. A controversial breach of a dam in Tibet in 2000 resulted in devastating floods

\footnotetext{
${ }^{212}$ Sarma, supra note 187 at 73.

213 Ojha \& Singh, supra note 186 at 11-13.

${ }^{214}$ ANH Akhtar Hossain, People's Initiative for Transboundary River Basin Management (Paper presented to the International Conference on Regional Cooperation on Transboundary Rivers: Impact of the Indian River linking Project, Dhaka, 2004) at 341.

${ }^{215}$ Ojha \& Singh, supra note 186 at 2.

216 Upreti, supra note 186 at 83.

${ }^{217}$ AD Mobile, "Brahmaputra: Issues in Development" " in Asit K Biswas \& Juha I Uitto, eds, Sustainable development of the Ganges-Brahmaputra-Meghna Basins (New York: United Nations University Press, 2001) at 62.

${ }^{218}$ See generally, Dutta, supra note 184.
} 
in Arunachal Pradesh. ${ }^{219}$ There is also concern that China will withhold water for power generation and irrigation during the dry season while releasing water during the flood season. In addition, India is currently engaged in a project to transfer water from surplus regions to deficit basins by linking 30 rivers by 2020 (the "River-linking Project"). ${ }^{220}$ However, China's threatened diversion of the Brahmaputra would render India's River Linking Project redundant and would severely jeopardize India's water security.

According to one media source, "[i]f Beijing goes ahead with the Brahmaputra project, it would practically mean a declaration of war against India." 221 .

Despite the potential for conflict, Ojha \& Singh conclude that there exists a good possibility of cooperation between India and China. ${ }^{222}$ Specifically, the authors note that the river drops from $3,350 \mathrm{~m}$ in the Tibetan Plateau to $800 \mathrm{~m}$ in India, such that the ability to efficiently harness the river's greatest hydropower potential requires cooperation of both countries:

The valley characteristics are such that the river at the point of diversion is in China, and the site of the powerhouse is in India. Therefore it requires the cooperative effort of both countries to generate energy from the colossal 'Power Store House'. ${ }^{223}$

A Sino-Indian bilateral agreement may appeal to both regional powers. ${ }^{224}$

However, the Tsangpo-Brahmaputra River Basin is located in a hypersensitive political zone. Arunachal Pradesh was also the location of the 1962 Border War between China \& India. China continues to regard India's control of Arunachal Pradesh as an

\footnotetext{
${ }^{219}$ Tsering (2005), supra note 186 at 46.

${ }^{220}$ Iftikhar Gilani, "China's move to divert Tibetan rivers upsets India's plan" The Daily Times (43 November 2003), online: The Daily Times <http://www.dailytimes.com.pk/default.asp?page=story_3-112003_pg7_11>.

${ }^{221}$ Ibid.

${ }^{222}$ See generally, Ojha \& Singh, supra note 186.

${ }^{223}$ Ibid at 14.

${ }^{224}$ Beach et al, supra note 4 at 50 .
} 
illegal occupation and refers to the area as South Tibet. While the parties tentatively observe a Line of Actual Control, ${ }^{225}$ the conflict over Arunachal Pradesh remains the greatest potential source of conflict between China and India. ${ }^{226}$ Recently, China's developments on the Tsangpo-Brahmaputra dangerously close to the Sino-Indian border have renewed concern for the threat that China poses to India. ${ }^{227}$

\section{b) Indigenous Peoples' Interests in the Tsangpo-Brahmaputra River Basin}

According to Tibetan legend, the Great Bend of the Tsangpo is the heart of the mythical Shangri-La. In the sacred texts of Tibetan Buddhism, this mysterious land holds the promise of an existence without "poverty, hatred, hypocrisy, cheating or death". ${ }^{228}$ Tibetans believe the Great Bend to be the home of the Goddess Dorje Pagmo, Tibet's Protecting Diety. ${ }^{229}$ Tibetan scholar, Tashi Tsering, describes the significance of the Tsangpo:

To the Tibetans, the Great Bend region is known as Pema Koe, the most sacred beyul blessed by Guru Rinpoche, Padmasambhava, the Indian Buddhist yogin credited with firmly establishing Buddhism in Tibet. Generations of visionary Tibetan Buddhist masters have revealed "hidden treasures" ... and made journeys through the different layers of spiritual doors of beyul Pema Koe. ${ }^{230}$

\footnotetext{
${ }^{225}$ The Line of Actual Control (LAC) approximates the McMahon Line that is found in a 1914 agreement initialled by British, Tibetan, and Chinese representatives. However, China refuses to acknowledge the validity of the McMahon Line and the LAC does not constitute an officially demarcated border. See Rong Ying, "Remembering a War: The 1962 India-China Conflict", Rediff (December 2002) online: Rediff < http://www.rediff.com/news/2002/dec/20chin.htm>.

${ }^{226}$ Global Security "Indian-China Border Dispute", online Global Security <http://www.globalsecurity.org/military/world/war/india-china_conflicts.htm>. For an assessment of the threat of a water war between Indian and China linked to historical territorial conflict, see Jonathan Holslag, "Assessing the Sino-Indian Water Dispute" (2011) 64:2 Journal of International Affairs 19.

${ }^{227}$ Arpi (2011), supra note 205; Dean Nelson "Dalai Lama attacks China's claim of sovereignty over India's Arunachal Pradesh" The Telegraph (09 Nov 2009), online: The Telegraph $<$ http://www.telegraph.co.uk/news/worldnews/asia/india/6531093/Dalai-Lama-attacks-Chinas-claim-ofsovereignty-over-Indias-Arunachal-Pradesh.html>.

${ }^{228}$ Weiji, supra note 195.

${ }^{229}$ Arpi (2003), supra note 204.

${ }^{230}$ Tashi Tsering, "Damming Tibet's Yarlung Tsangpo-Brahmaputra and other South Asian rivers" Tibetan Plateau (24 May 2010), online: Tibetan Plateau Blogspot 〈http://tibetanplateau.blogspot.com/2010/05/damming-tibets-yarlung-tsangpo.html〉.
} 
For many, the question of Tibet's status within China has never been adequately resolved. China has enjoyed de facto control over the Indigenous peoples of Tibet since the invasion by the People's Liberation Army of China in $1949 .^{231}$ China bases its claim to Tibet on historical events dating back to the height of the Mongol imperial expansion and the influence of Manchu Emperors in the $18^{\text {th }}$ century. However, the Government of Tibet in Exile and its supporters, assert that at the time of China's invasion, Tibet was an independent state recognized under international law. ${ }^{232}$ While Tibet sent an urgent appeal for help to the United Nations, the General Assembly did not take any action for fear of provoking a full-scale attack by China. However, in the years following China's military occupation of Tibet, many countries continued to recognize Tibet's independence during full debates on the issue in the United Nations General Assembly in 1959, 1960, 1961, and 1965. Further, in 1959, 1961 and 1965, the UN issued Resolutions condemning the violation of Tibetan peoples' fundamental rights and freedoms. ${ }^{233}$ Since that time however, the United Nations has failed to adequately address the issue of Tibet's statehood. The lack of international resolve regarding the issue of Tibetan peoples' rights to self-determination and China's human rights violations in that region must be viewed within the context of China's current initiatives to exploit Tibet's natural resources. The United Nations cannot easily facilitate negotiations towards a regional

\footnotetext{
${ }^{231}$ Central Tibetan Administration, Tibet under Communist China: 50 Years (2001), online: <http://tibet.net/wp-content/uploads/2011/08/TibetUnderCommunistChine-50Years.pdf>.

${ }^{232}$ Ibid; Regina M Clark, "China's Unlawful Control Over Tibet: The Tibetan People's Entitlement to SelfDetermination” in (2001-2002) 12 Ind Int'l \& Comp L Rev 293.

${ }^{233}$ Free Tibet, "United Nations Resolutions on Tibet", online: Free Tibet <http://www.freetibet.org/about/united-nations-tibet>.
} 
transboundary agreement in this watershed without also addressing the rights of the Indigenous peoples of Tibet. ${ }^{234}$

The issue of Tibetan peoples' self-determination has implications beyond those raised by the Tsangpo Project. The Tibetan Plateau is the principal watershed in Asia and the source of its 10 major rivers. ${ }^{235}$ According to Claude Arpi, "Tibet's waters flow down to eleven countries and are said to bring fresh water to over 85 percent of Asia's population, approximately 50 percent of the world's population." ${ }^{236}$ Environmental governance in Tibet is therefore of paramount concern in Asia and throughout the world. The international importance of Tibet's resources prompted the spiritual leader of Tibetans, the Dalai Lama, to propose a 5 Point Peace Plan to turn Tibet into a zone of “Ahimsa", a Sanskrit word meaning "non-violence." 237 The Dalai Lama set out his proposal in his 1989 Nobel Peace Prize acceptance speech:

This included the conversion of the entire Tibetan plateau into a Zone of Ahimsa, a sanctuary of peace and nonviolence where human beings and nature can live in peace and harmony. ... Any relationship between Tibet and China will have to be based on the principle of equality, respect, trust and mutual benefit. ${ }^{238}$

Maintaining the health of Tibet's water resources is vital to the future of Asia as a whole. Moreover, Tibetans rely upon Tsangpo and their natural environment for their spiritual and cultural continuity.

In addition to the very high-profile plight of the Tibetan struggle for selfdetermination, there are hundreds of lesser-known Indigenous communities that live

\footnotetext{
${ }^{234}$ Mitterand, supra note 204.

${ }^{235}$ Arpi (2003), supra note 204; Mitterand, supra note 204.

${ }^{236}$ Arpi (2011), supra note 205.

${ }^{237}$ Shukavak N Dasa , "Non Harming: Ahimsa” A Hindu Primer (2007), online: Sanskrit Religions Institute <http://www.sanskrit.org/www/Hindu\%20Primer/nonharming_ahimsa.html>.

${ }^{238}$ Dalai Lama, "Nobel Peace Prize 1989 The $14^{\text {th }}$ Dalai Lama Acceptance Speech" (1989), online: Nobel Prize, <http://nobelprize.org/peace/laureates/1989/lama-acceptance.html>.
} 
along the Brahmaputra in Arunachal Pradesh, Assam and Bangladesh. Approximately $65 \%$ of the Arunachalis belong to 20 major-collective tribes and 82 smaller tribes, many of which are either of Tibetan or Thai-Burmese origin. The other $35 \%$ of the population are immigrants. Similarly, Assam is characterized as "multi-racial, multi-ethnic, multireligious, multi-caste, multi-cultural, and multi-lingual". ${ }^{239}$ This region is beset with ongoing internal conflicts throughout the river valley. ${ }^{240}$

In September 2010, fifty-one organizations representing Indigenous peoples and local communities in India's Northeast signed on to a letter to India and China in an appeal to stop the damming of the Tsangpo-Brahmaputra:

We submit this memorandum to the leaders of two of the largest economies on this earth, India and China, hoping that there will be sanity and boldness in dealing with the proposed dams in upper and lower reaches of Yarlung Sangpo/Siang/Brahmaputra Rivers. Several communities in this stretch of river identify it by several names and [attach] spiritual, cultural and economic importance to Nature, and they are first users and in fact the defender and protector of the river and its ecosystem. We fear that this being not only one of the finest rivers but also the finest ecosystems on earth, the communities surviving on this ecosystem will be destroyed by the politics of water and energy and the game of one-upmanship of these great nations. ${ }^{241}$

The signatories perceive the growing conflict between China and India for dominance

over the river basin as a growing threat. They further state:

We have witnessed painful conflict between India and China in the sixties and we do not want to see the conflict continue or escalate as ultimately it is the people [who] suffer (like those who live in Arunachal, in particular). We see that there is already an additional conflict brewing due to the dams proposed both by China and India. For this reason both [countries] must refrain from building any dams in the whole stretch of this river. This will help build peace and trust between the two countries. Building dams on

\footnotetext{
${ }^{239}$ M Hussain, "Society in the Brahmaputra Valley" in Singh et al, supra note 186, 336 at 336.

${ }^{240}$ Ibid at 349.

${ }^{241}$ North East Peoples Alliance, "Memorandum to India and China Against Dams on Yarlung Tsangpo", 17 September 2010, online: North East Peoples Alliance, <http://nealliance.net/nepa/memorandum-to-indiaand-china-against-dams-on-yarlung-tsangpo/>.
} 
Siang or in Yarlung Sangpo will therefore be considered as seeking conflict. $^{242}$

The groups make two proposals:

1. Stop all existing and proposed dam construction activities on Siang River both in China and India.

2. Collectively agree to hold these river(s) as Heritage Rivers for all future generations to come. ${ }^{243}$

The signatories include several organizations representing Indigenous interests including:

Nefa Indigenous Human Right Organisation, Arunachal Pradesh; Forum for Indigenous

Perspectives and Action, Manipur; Dialogue on Indigenous Culture and Environment,

Nagaland; United Tribal Development Project, Manipur; Indigenous People Foundation,

Arunachal; World Mountain Peoples Forum, Meghalaya; All Tribal Student Union,

Manipur; and the Sinlung Indigenous Peoples Human Rights Organization.

\section{c) Discussion}

The Tsangpo-Brahmaputra is a potential flashpoint for conflict in Asia. Both China's Tsangpo Project and India's River-Linking Project threaten the water supply to downstream riparians affecting millions of people and threatening the environment for future generations. The situation is complicated by unique geopolitical dynamics that include two regional superpowers on the one hand and extremely vulnerable Indigenous populations on the other. The impact of the proposed projects must also be considered within the context of climate change, flooding, deforestation, erosion and seismic activity, which will require joint study and information sharing.

The geo-political dimensions surrounding the Tsangpo-Brahmaputra River Basin are unique in the world. Unlike most transboundary disputes that involve one regional

$$
\begin{aligned}
& { }^{242} \text { Ibid. } \\
& { }^{243} \text { Ibid. }
\end{aligned}
$$


power, the Tsangpo-Brahmaputra is shared by two regional superpowers, which are also emerging global powers. Between them, China and India have $40 \%$ of the world's population. ${ }^{244}$ Both China and India are experiencing massive population growth, unprecedented economic development and an unsustainable demand for natural resources. While China and India have incentives to cooperate in the development of the Tsangpo-Brahmaputra, they also have a recent history of armed conflict in this Basin. In addition, China's claim to Tibet is still contested by human rights and Indigenous activists. The development of the Tsangpo by China has the potential to further politicize and polarize these issues within the international community and lead to further violent conflict. Any approach to facilitating transboundary governance in this region must allow all peoples to engage in cooperation without requiring any group to accede its position regarding sovereignty and rights to self-determination.

In particular, the stakeholders will be challenged to overcome unique power inequities, disputes regarding sovereignty, and the current lack of capacity for transboundary and participatory approaches to decision-making. In addition to a myriad of issues confronting this region, ongoing disputes regarding sovereignty in the region make the application of international water law principles problematic in this region. Any attempt to enforce the rights and obligations of sovereign nations regarding this river triggers issues regarding sovereignty and potentially exacerbates tensions regarding China's controversial domination over Tibet and ongoing conflict between China and India regarding disputed territories. China has expressly rejected the principles of customary international water law as an infringement on its absolute territorial

\footnotetext{
${ }^{244}$ Flavin \& Gardner, supra note 195 at 7.
} 
sovereignty. ${ }^{245}$ China might be persuaded to see the merits of a bilateral agreement with India but historically, China has simply acted with impunity as an upstream riparian. While the potential for a 'mutual gains' approach to negotiations might persuade China and India to strike a mutually beneficial deal which is compatible with international water law principles, it would pose considerable risk to the Indigenous peoples along the river who will be adversely impacted by such joint development. Indigenous peoples have no protection under international water law.

The 'reasonable and equitable use' doctrine and the 'no harm' rule codified in the UN Watercourse Convention do not provide any protection to Tibetans or the local tribes of Arunachal Pradesh and Assam. It is simply assumed that riparian states will represent the best interests of the people and environment within their territory. The current structure, "excludes minority political or ethnic groups, as well as a whole range of political, environmental and special interest groups who may have a stake in an international agreement." 246 The current focus on sovereignty is inconsistent with the preservation of the internationally affirmed rights of Indigenous peoples and environmental protection and must be revisited. ${ }^{247}$ The key may be to reframe the issue. Green Cross International proposed that.

...instead of grappling for a restrictive middle ground between upstream and downstream riparian claims, and mutually unsatisfactory compromise, the problem should be reformulated and directed away from questions of different degrees of sovereignty towards a vision of cooperation. ${ }^{248}$

\footnotetext{
${ }^{245}$ UN GA Res GA/9248, supra note 97.

${ }^{246}$ Beach et al., supra note 4 at 44.

${ }^{247}$ Klaus Bosselmann, "Environmental Governance: A New Approach to Territorial Sovereignty" in Robert J Goldstein, ed., Environmental Ethics and Law (Great Britain: The Cromwell Press, 2004) 293 at 309 [Bosselmann].

${ }^{248}$ Green Cross International, National Sovereignty and International Watercourses (The Hague: Ruckstahl SA: 2000) at 13 .
} 
The focus on sovereignty as the organizing principle of international water law and governance fails to adequately address the complexity of transboundary cooperation in the Tsangpo-Brahmaputra River basin. ${ }^{249}$

In addition, advocates of participatory models of water governance will encounter unique issues in the Tsangpo-Brahmaputra River basin given the unresolved issues regarding sovereignty. Any encouragement or requirement for a state to adopt participatory approaches in a region implicitly assumes that the state has the legitimate right to govern and develop the resources in that region. There may be unintended consequences to advocating China or India's adoption of participatory governance in regions that are in dispute such as Tibet or Arunachal Pradesh. For example, if the World Bank or United Nations encourages China to adopt participatory approaches or other specific governance strategies in Tibet, are they inadvertently legitimizing China's claim to sovereignty over Tibet? Could Tibetan peoples meaningfully participate in local governance initiatives without formerly acceding to China's claims to absolute sovereignty? To borrow from Professor Christie's characterization of Indigenous peoples’ struggles in Canada, “...Aboriginal nations find themselves forced to welcome the opportunity to be consulted about how their own lands will be exploited."250 Even if one accepts that China's claim to Tibet as settled, the people of Tibet possess rights under the international law of Indigenous peoples. ${ }^{251}$ The challenge to the international

\footnotetext{
${ }^{249}$ Bosselmann, supra note 247 at 293; Bradley C Karkkainen, "Transboundary ecosystem governance: Beyond sovereignty?" in (eds) Carl Bruch, Libor Jansky, Mikiyasu Nakayama, \& Kazimierz A Salewicz, Public Participation in the Governance of International Freshwater Resources (New York: United Nations University Press, 2005) at 73 [Karkkainen].

${ }^{250}$ Gordon Christie, "A Colonial Reading of Recent Jurisprudence: Sparrow, Delgamuukw and Haida Nation" (2005) 23 Windsor YB Access Just 17 [Christie].

${ }^{251} \mathrm{~S}$ James Anaya, "Self-determination as a Collective Human Right Under Contemporary International Law" in (eds) Pekka Aiko and Martin Scheinin, Operationalizing the Right of Indigenous Peoples to SelfDetermination (Finland: Institute for Human Rights, 2000) at 3.
} 
community is therefore how to create international laws regarding transboundary river governance in a manner that ensures meaningful cooperation and dialogue without inadvertently legitimizing and encouraging further colonial domination.

\subsection{Conclusions: The Problem With Sovereignty}

The focus on territorial sovereignty leads to a domination of rich states over poor, of today's interests over tomorrow's and of human needs over environmental needs. This 'logic of self-extermination' is bound to fail and must be replaced by a different logic. ${ }^{252}$

Klaus Bosselmann

The doctrine of sovereignty is an obstacle against, rather than a vehicle for the peaceful governance of transboundary rivers. ${ }^{253}$ A critical analysis of the $U N$ Watercourse Convention, related mainstream discourse and two case examples demonstrates the inability of international water law to recognize the international rights of Indigenous peoples.

The prevailing theory of international watercourse rights and obligations today is "limited territorial sovereignty," which dictates that "the sovereignty of a state over its territory is said to be 'limited' by the obligation not to use that territory in such a way as to cause significant harm to other states". ${ }^{254}$ This principle is codified in the $U N$ Watercourse Convention and has been supported in international courts and tribunals in cases involving international watercourses. It is generally accepted that customary international law imposes limitations on a state's freedom with respect to the portion of

\footnotetext{
${ }^{252}$ Bosselmann, supra note 247 at 305.

${ }^{253}$ Ibid at 309, where Bosselmann states “.... State sovereignty may be more an obstacle against, rather than a vehicle for, global environmental protection."

${ }^{254}$ McCaffrey (2007), supra note 5 at 135; Beach et al., supra note 4 at 12.
} 
an international watercourse within its territory. ${ }^{255}$ This limitation upon absolute territorial sovereignty has been heralded as an indicator of international cooperation and sharing of resources signalling a new era of transboundary governance. However, a closer examination of the discourse surrounding international water law reveals that "territorial sovereignty remains the dominant limiting factor in defining the scope of international water law.",256

The UN Watercourse Convention has been hailed by both its supporters and detractors alike as a landmark departure from the doctrine of historical sovereignty. ${ }^{257}$ However its reliance upon sovereign status continues to operate as a barrier to Indigenous peoples' participation in the development and application of transboundary water law. Indigenous peoples' rights are not mentioned in the UN Watercourse Convention; accordingly, they have no access to dispute resolution mechanisms under the Convention. The equitable principles codified in the Convention simply do not apply to Indigenous peoples. The Convention does not require states to recognize Indigenous rights ratified in other international agreements or to obtain Indigenous peoples' informed consent for decisions that might impact them. ${ }^{258}$ Likewise bilateral and multilateral state agreements that drive the evolution of customary international law principles simply do not acknowledge or mention Indigenous rights and instead focus on maximizing mutual gains through state cooperation. In this paradigm, Indigenous peoples' rights are reduced to a cost of development. The mainstream discourse and texts regarding international water law often neglect to acknowledge Indigenous peoples' interests in transboundary

\footnotetext{
${ }^{255}$ McCaffrey (2007), ibid; Dellapenna, supra note 98.

256 Thorson, supra note 7 at 513.

257 UN GA Res GA/9248, supra note 97.

${ }^{258}$ UNDRIP, supra note 13 at Art 32(2).
} 
disputes. While transboundary water governance theories such as IWRM and IWI are more conducive to Indigenous peoples' participation in environmental decision-making, Indigenous peoples are still often lumped together with other "stakeholders" such as industry and NGOs, thereby undermining their international status and collective rights.

The issues confronting Indigenous peoples are further revealed in the two transboundary case examples cited above. In the context of the Columbia River, Indigenous peoples are relatively empowered with strong national legal rights. However, their transboundary claims for compensation for past harms are routinely dismissed as a domestic issue. While both the United States and Canada have sophisticated legal regimes protecting Indigenous rights, both nations have been slow to acknowledge Indigenous peoples' international rights under UNDRIP and Canada continues to assert that, despite its endorsement of UNDRIP, it is not customary international law. ${ }^{259}$ In this context, Indigenous peoples' international rights to participate in environmental decisionmaking in transboundary rivers are only realized to the extent that states agree to recognize them. International water law does not require states to recognize or even acknowledge Indigenous rights. Under the UN Watercourse Convention, two states could reach a mutually beneficial agreement and proceed to develop a transboundary river without ensuring Indigenous peoples' participation and informed consent. They could be well within the parameters of customary international water law while violating a number of other ratified international conventions. Indigenous peoples are left to seek compensation after-the-fact reinforcing the notion that their legal interests can be reduced to a cost of development.

\footnotetext{
259 Aboriginal Affairs and Northern Development Canada, Canada's Statement of Support on the United Nations Declaration on the Rights of Indigenous Peoples, (12 November 2010), online: Aboriginal Affairs and Northern Development Canada < http://www.aadnc-aandc.gc.ca/eng/1309374239861>.
} 
In the context of the Tsangpo-Brahmaputra River, extremely vulnerable

Indigenous populations are at the mercy of two major superpowers with disputed borders, both of which are pursuing mega-dam developments. While an agreement between China and India would be consistent with the objectives of the UN Watercourse Convention, a bilateral agreement emphasizing a mutual gains approach would likely be disastrous for Indigenous populations. Even participatory approaches to governance could have the effect of undermining long-standing claims to sovereignty asserted by Indigenous peoples by presuming state responsibility to manage consultation processes.

One of the most glaring omissions in international water law today is the lack of a dispute mechanism for transboundary water disputes that can be accessed by Indigenous peoples and which integrates international environmental laws. Wolf states:

One of the greatest gaps in international water dispute resolution is the lack of just such recognized authority. Wescoat (1992) describes the elaborate process by which the International Law Commission, the United Nations legal body, has taken to design a draft code of international waters. The 24year effort, only recently approved by the General Assembly, includes terms defined by politics rather than science, vague and contradictory doctrines, and no enforcement mechanism. Even approved, international law applies only to States, and therefore ignores many of the ethnic minorities who might claim water rights. Furthermore, the International Court of Justice requires not only that both parties to a dispute agree to the Court's jurisdiction, but also that they agree to the specific point of law to be decided. $^{260}$

This deconstruction of the Convention, the discourse and the case examples, illustrates a disturbing lack of acknowledgement for the international status and rights of Indigenous peoples. ${ }^{261}$ The roots of this inequity can be traced to the emphasis on sovereignty as the

\footnotetext{
${ }^{260}$ Aaron T Wolf, “Indigenous approaches to water conflict negotiations and implications for international waters" (2000) 5 International Negotiation: A Journal of Theory and Practice 2 at 11 [Wolf].

${ }^{261}$ An argument could also be made that the definitions contained in the UN Watercourse Convention and international water law negate Indigenous peoples' experience and rights. The definition of a
} 
organizing principle of international water law. The emphasis placed upon sovereign status may operate to adversely impact upon Indigenous peoples in the following ways:

(1) It excludes Indigenous peoples from international negotiations regarding transboundary rivers and from participating in the development of international water law principles;

(2) It presumes that Indigenous peoples' interests in transboundary rivers are a domestic issue, thereby reinforcing Indigenous peoples as subordinate to the states oppress them and perpetuating ongoing colonization of Indigenous peoples by states;

(3) It undermines international conventions and declarations that have affirmed the rights of Indigenous peoples to fully participate in environmental decision-making; and

(4) It may exacerbate conflict over disputed territories and unintentionally encourage states to expand their territories.

In addition to the impacts discussed above, the exclusion of Indigenous peoples from participating in international governance has led to the exclusion of Indigenous values from the development of customary international law of transboundary watercourses. Customary international water law has been, and continues to be, largely distilled from the bilateral and multilateral agreements between states. The Convention and discourse are predicated upon Western perspectives of sovereignty and ownership of resources, which perceives rivers primarily as a resource for economic exploitation. ${ }^{262}$ State agreements are largely agreements to mutually develop and govern the river in an effort to maximize states' economic interests. The presumption of gains, development and utilization dominates the discourse and negates the notion of valuing the river in its

'transboundary river' as meaning only rivers that cross the borders of sovereign states effectively negates the reality that many rivers traverse the boundaries of several Indigenous territories.

${ }^{262}$ David Groenfeldt, "Water Development and Spiritual Values in Western and Indigenous Societies" in R. Boelens, M. Chiba \& D. Nakashima, eds. Water and Indigenous Peoples (Paris: UNESCO, 2006) 108, online: UNESCO <http://portal.unesco.org/science/en/ev.php-

URL_ID=4901\&URL_DO=DO_TOPIC\&URL_SECTION=201.html> [Groenfeldt (2006)]. 
undeveloped state or the inherent value of conservation and protection of the watershed. The spiritual or cultural importance of rivers throughout the world is largely absent from the discourse. ${ }^{263}$ By relying solely upon states' interests and a Western classical notion of sovereignty, international water law is predicated upon values that contradict and exclude an understanding of Indigenous peoples' experience of sovereignty and relationship with water.

Wouters \& Tremblay caution that a critical analysis of international water law aimed at identifying its failure to address human rights must also recognize the historical context of both areas of law. The authors state that the UN Watercourse Convention:

... hails from the UN Charter's higher-level objectives of maintaining 'international peace and security', and achieving 'international cooperation'. Thus through treaty and state practice, rules evolved that came to govern trans-boundary waters traversing national borders. The core focus in this area of public international law has been the peaceful management of shared resources - as complementary to other rules that might evolve under the law of nations, such as 'promoting and encouraging respect for human rights'. Thus the origins of the discourse for each of these areas of public international law were quite distinct and must be understood more deeply within this context. ${ }^{264}$

While I duly acknowledge that, to date, international water law has evolved independently from the discourse on human rights and indigenous peoples' rights, this purpose of this thesis is to consider how it might be improved upon in the future from an Indigenous perspective. The first step in such an analysis must involve identifying its shortcomings in this regard.

Critical Race Theory has informed my analysis and deconstruction of transboundary water law to identify how the UN Watercourse Convention and the

\footnotetext{
263 Ibid.

${ }^{264}$ Patricia Wouters \& Hugo Tremblay, Book Review of Freshwater Access from a Human Rights Perspective by Knut Bourquain (2009) 10:2 Melbourne J Int'1 L 705.
} 
doctrine of sovereignty have operated to subordinate Indigenous peoples. The next chapter explores several perspectives regarding Indigenous peoples' relationship with the concept of sovereignty. A review of the literature reveals how sovereignty has been intentionally constructed to exclude Indigenous peoples from the dominant social contract. It considers not only how the concept of sovereignty was manipulated and developed by Western lawmakers to dominate Indigenous peoples and exploit natural resources but also acknowledges the multiplicity of ways that Indigenous peoples understand and experience sovereignty. These alternate narratives show that sovereignty is a "social creation" 265 that is both culturally and historically dependent. Once we appreciate our role in creating and defining sovereignty, we can acknowledge our ability to transform it and consider alternatives to transboundary governance that are premised on mutual respect for all peoples and a vision of cooperation.

${ }^{265}$ Alfred (2005), supra note 40 at 46. 


\title{
Chapter 3: Sovereignty as a Social Construct: Indigenous Perspectives
}

\author{
Sovereignty, then, is a social creation. ${ }^{266}$
}

Taiaiake Alfred, Mohawk

From an Indigenous perspective, the inequity that exists in transboundary water law is rooted in the operation of the historical doctrine of sovereignty. This doctrine has evolved to unilaterally exclude Indigenous peoples from the international legal order and subordinate Indigenous peoples' interests to state interests. Within the context of current international law, the doctrine of sovereignty refers to a nation's territorial integrity, exclusive jurisdiction and authority over a geographic area. ${ }^{267}$ The doctrine has become so embedded in our understanding of the modern world that it may at first seem absurd to challenge its foundational position as a pillar of international law. However, Barker contends that the meaning of 'sovereignty' can only be understood within its cultural and historical context:

... sovereignty is historically contingent. There is no fixed meaning for what sovereignty is - what it means by definition, what it implies in public debate, or how it has been conceptualized in international, national or indigenous law. Sovereignty - its related histories, perspectives, and identities - is embedded within the specific social relations in which it is invoked and given meaning. How and when it emerges and functions are determined by the "located" political agendas and cultural perspectives of those who rearticulate it into public debate or political document to do a specific work of opposition, invitation, or accommodation. ${ }^{268}$

At its essence, the doctrine of sovereignty is a social construct designed and defined by humans to reflect cultural values and achieve political gains. There is ample evidence

\footnotetext{
${ }^{266}$ Alfred (2005), supra note 40 at 46.

${ }^{267}$ Joanne Barker, "For Whom Sovereignty Matters" in J Barker, supra note 40, 1 at 1-2 [J Barker (2005)]

${ }^{268}$ Ibid at 21.
} 
that the doctrine of sovereignty has evolved within the Western legal system as a tool of colonialism to intentionally negate Indigenous rights and gain control over land and resources. $^{269}$ In the process, the dominant discourse on sovereignty has also greatly diminished and endangered Indigenous epistemologies, culture and identity. ${ }^{270}$ By engaging and articulating the varied and diverse Indigenous perspectives on sovereignty and exploring other potential modalities of sovereignty, ${ }^{271}$ a process of epistemological and cultural reclamation is also occurring.

How we understand sovereignty is ultimately a reflection of deeply held personal and cultural beliefs about one's place in the world and our relationship to others. Alfred asserts that " $[\mathrm{t}]$ he reification of sovereignty in politics today is the result of a triumph of a particular set of ideas over others - no more natural to the world than any other manmade project." 272 The term is socially constructed and historically dependent. ${ }^{273}$ It is both amorphous and unassailable. It is personal, spiritual and political. It is derived from harmonious relations and exploited for domination and oppression. A review of the literature reveals that Indigenous views of sovereignty are as varied and complex as Indigenous cultures.

In this chapter, I review some of the varied understandings of sovereignty within Indigenous scholarship. Taken together, the resulting narratives provide a counterpoint to the dominant legal discourse and demonstrate that sovereignty is a human-made construct, which is neither objective nor neutral. Once we understand that sovereignty is

\footnotetext{
${ }^{269}$ Antony Anghie, Imperialism, Sovereignty, and the Making of International Law (Cambridge: Cambridge University Press, 2007).

${ }^{270}$ Ibid at 19.

${ }^{271}$ Christie, supra note 250; June McCue, "New Modalities of Sovereignty: An Indigenous Perspective" (2007) 2 Intercultural Human Rights L Rev 19 [McCue].

272 Alfred (2005), supra note 40 at 46.

273 J Barker (2005), supra note 267.
} 
a "social creation", ${ }^{274}$ we can begin to recognize our collective ability and responsibility

to create new laws that are inclusive of Indigenous perspectives. Historical context is

particularly relevant to a critical Indigenous analysis of the doctrine of sovereignty and

the recognition of Indigenous peoples' rights. Richardson, Imai \& McNeil observe:

We should nonetheless be vigilant of the historical context of Indigenous rights, as failure to make the connection between the continuing impact of past government policies and the contemporary plight of Indigenous peoples can foster antagonism in wider society towards necessary remedial and special measures. Moreover, some people wrongly regard the Indigenous struggle for rights as a recent phenomenon ... In fact, Indigenous resistance to colonialism and its legal machinery has been waged for centuries, and continues today... ${ }^{275}$

A brief review of historical Western understandings of sovereignty provides context for exploring Indigenous peoples' experience and understanding of sovereignty.

\title{
3.1 Providing Context: Sovereignty in Western Traditions
}

\author{
By art is created that great Leviathan, \\ called a commonwealth or state, (in Latin civitas) \\ which is but an artificial man ... \\ in which the sovereignty is an artificial soul. ${ }^{276}$
}

Thomas Hobbes, in Leviathan (1651)

Today, the doctrine of sovereignty is deeply entrenched in international law and is correlated with territorial integrity, exclusive jurisdiction and authority to control a geographical area. ${ }^{277}$ However, the notion of sovereignty is an ancient one. ${ }^{278}$ Aristotle

\footnotetext{
${ }^{274}$ Alfred (2005), supra note 40 at 46.

${ }^{275}$ Benjamin J Richardson, Shin Imai \& Kent McNeil, "Indigenous Peoples and the Law - Historical, Comparative and Contextual Issues" in Indigenous Peoples and the Law: Comparative and Critical Perspectives, Benjamin J Richardson, Shin Imai and Kent McNeil, eds, (Portland: Hart Publishing, 2009) 3 at 5 [Richardson et al].

${ }^{276}$ Thomas Hobbes, Leviathan (1651), excerpt reprinted in Elizabeth Knowles, ed, The Oxford Dictionary of Quotations $\left(5^{\text {th }}\right.$ ed) (Oxford: Oxford University Press: 1999) 378.

277 J Barker (2005), supra note 267 at 3.
} 
meditated on who should be entitled to wield moral authority over a city in his chapter on Justice \& Sovereignty in The Politics as early as $4^{\text {th }}$ century BCE. ${ }^{279}$ In different historical contexts, sovereignty has been invoked to describe an individual's authority over oneself, to refer to the power of God or other deities over humanity and to affirm the inherent power of feudal lords and monarchs over their citizens. Over time, the notion of state sovereignty evolved as a pillar of the law of nations. Barker summarizes the early theoretical debates over sovereignty:

In some early debates, it was argued that sovereignty emanated from individuals (citizens). Individuals possessed rights to personal freedoms that informed their collective rights to rule themselves as nations.

$\cdots$

In other debates, sovereignty was linked to the "law of nations." Therein nations were based on the collective rights of individuals to civil society, life, happiness, property, justice, and defense; nations held rights to be free, independent and respected as equals in the pursuit of securing the collective rights of their citizens.

...

In both kinds of debates, sovereignty was about figuring out the relationship between the rights and the obligations of individuals (citizens) and the rights and obligations of nations (states). Sovereignty seemed to belong to nations but was then understood to originate either from the people who made up those nations or as a character of the nation itself (nationhood). ${ }^{280}$

Ultimately, sovereignty is about power; where it is located and why. Far from being

fixed, the concept of sovereignty is both culturally and historically dependent even within Western classical traditions. ${ }^{281}$ This section does not endeavour to provide a comprehensive review of Western classical traditions regarding the notion of

\footnotetext{
${ }^{278} \mathrm{~J}$ Barker (2005), ibid at 1-2.

${ }^{279}$ Aristotle, The Politics, revised ed, trans by T.A. Sinclair, revised and re-presented by Trevor J. Saunders (London: Penguin Books, 1992). Note however that while the word "sovereignty:" was used in translation, that the etymology of the word only traces back to the $14^{\text {th }}$ century. See Online Etymology Dictionary at <http://www.etymonline.com/index.php?term=sovereignty>.

${ }^{280} \mathrm{~J}$ Barker (2005), supra note 267 at 2.

${ }^{281}$ Ibid at 21.
} 
sovereignty. ${ }^{282}$ Rather, it is intended as a brief overview of the evolution of Western

legal tradition of sovereignty to provide context for considering indigenous perspectives.

\subsubsection{Feudal Europe}

Prior to the "law of nations", ${ }^{283}$ sovereignty was typically considered the domain of the church as mediator of God's will as the only "true sovereign". ${ }^{284}$ Monarchs and feudal lords exploited its religious associations and claimed that their right to rule was derived from God's will. ${ }^{285}$ In feudal Europe, individual rulers claimed sovereignty over peasants and lesser feudal lords as a form of "absolute power over everyone and everything" within their claimed territory. ${ }^{286}$ According to Anaya:

In the Europe of the high Middle Ages, sovereignty and political loyalties were fragmented, resulting in shifting and overlapping political communities. Against this backdrop of evolving political interdependencies and the perception of a normative order applying throughout humanity, theorists discerned rights and duties as applying beyond limited denominations of human association such as "nation," "state," or "kingdom." 287

Citizens were perceived to consent to the sovereign authority of their lords and monarchs in return for their armies' protection.

\subsubsection{European Conquest and the New World}

The discovery of the New World by Christopher Columbus radically shifted the way Europeans conceived of sovereignty. European theorists such as Dominican clerics Bartolomé de las Casa (1474-1566) and Francisco de Vitoria (1486-1547) raised moral

\footnotetext{
${ }^{282}$ For further reading, see Anaya (2004), supra note 10 at Part I. Developments Over Time. For a critical analysis of how social contract theory evolved to negate of race and indigenous rights, see Mills, supra note 112.

${ }^{283}$ Anaya (2004), supra note 10 at 20.

${ }^{284} \mathrm{~J}$ Barker (2005), supra note 267 at 2.

${ }^{285} \mathrm{Ibid}$

${ }^{286}$ John Mohawk, "On Sovereignty" (1995) 1:3/4 Akwesasne Notes, reprinted in Robert Odawi Porter, ed, Sovereignty, Colonialism and the Indigenous Nations: A Reader (North Carolina: California Academic Press, 2005) 137 at 138 [Mohawk].

${ }^{287}$ Anaya (2004), supra note 10 at 17.
} 
and legal issues regarding the legitimacy of conquest of the New World. ${ }^{288}$ As a Roman Catholic missionary who had spent years living among the Indigenous peoples of the New World, de las Casas defended the "essential humanity of the Indians". He was outspoken in his condemnation of the brutality of Spanish conquest and questioned the moral limits of the politics of conquest. ${ }^{289}$ De Vitoria, a theology professor who had never traveled off the continent, took a more theoretical interest in colonization and set about defining the rules of conquest. Anaya summarizes his contributions as follows:

Vitoria held that the Indians possessed certain original autonomous powers and entitlements to land, which the Europeans were bound to respect. At the same time, he methodically set forth the grounds on which Europeans could be said validly to acquire Indian lands or assert authority over them. ${ }^{290}$

Vitoria is credited with developing "a theory of just war" to justify Spanish claims which became pivotal to the European legitimization of conquest. ${ }^{291}$ Anaya describes how the contributions of Hugo Grotius (1583-1645) further developed this European view of conquest.

... Grotius affirmed that the ability to enter into treaty relationships is a necessary consequence of the natural rights of all peoples, including "strangers to the true religion": ... Grotius likewise endorsed the concept of just war, ... Grotius identified three broad "justifiable causes" for war or conquest: "defence, recovery of property, and punishment". ${ }^{292}$

Grotius' affirmation of the rights of Indigenous peoples' to enter into treaties was a precursor to the European tendency towards establishing treaties with Indigenous

\footnotetext{
${ }^{288}$ Ibid at 16.

${ }^{289}$ Ibid with reference to de las Casas - History of the Indies.

${ }^{290}$ Ibid.

${ }^{291}$ Ibid at 18.

${ }^{292}$ Ibid at 19.
} 
peoples. ${ }^{293}$ Likewise, his elaboration of the theory of just war formed the rationalization

for colonization and domination of Indigenous peoples. ${ }^{294}$

\subsubsection{Post-Westphalian Era 1658}

The Peace of Westphalia of 1648 is perceived by many to signal the beginning of the "era of the independent territorial state" 295 marking as it did not only the end of the Thirty Years War but also the political domination of the Roman Catholic Church. Harris describes the impact of the Peace of Westphalia on our current Western understanding of sovereignty:

The acquisition of sovereignty involved establishing and defending a territorial claim within which the state held supreme law-making authority. The Peace of Westphalia (1648), which established a temporary reprieve from decades of conflict in Europe, is widely considered the moment when emerging nation-states established the principle that each was sovereign. The basis of political authority had shifted away from a set of personal relationships between the sovereign and subject, and towards a notion of exclusive jurisdiction within defined territories. ${ }^{296}$

Anaya observes that the post-Westphalian period signalled a new era in theorizing about the state as a dichotomy emerged between individual rights and state rights. ${ }^{297}$ Anaya identifies philosopher Thomas Hobbes and diplomat Emmerich de Vattel as key contributors to the emerging theory of statehood.

The English philosopher Thomas Hobbes (1588-1679), in his major work, Leviathan (1651), posited that individuals lived in a warlike state of nature prior to joining civil society, represented by the state. Prominent theorists ... accepted Hobbes's vision of humanity as a dichotomy of individuals and states, and they began developing a body of law focused exclusively on states under the rubric of "the law of nations". 298

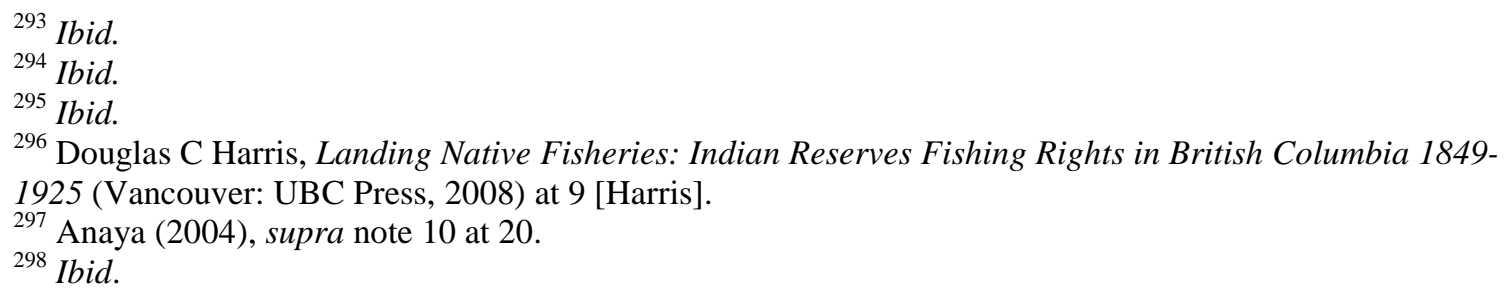


According to Hobbes, individuals lived naturally in a state of anarchic self-interest without any natural tendency towards peace and order. Individuals were therefore drawn towards association and entered into a "social contract" whereby a state was formed to protect the accumulated wealth of the individuals. States derived their rights to govern through the consent of those being governed.

In the mid- $18^{\text {th }}$ century, Swiss diplomat Emmerich de Vattel (1714-1769) published The Law of Nations, or The Principles of Natural Law (1758). ${ }^{299}$ According to Anaya:

... he defined the "Law of Nations" as "the science of the rights which exist between Nations or States, and the obligations corresponding to these rights. ... The individual/state dichotomy underlying Vattel's construct has powerfully affected the tradition of Western liberal thought. In contrast to the views of earlier naturalist theorists, the individual/state framework acknowledges the rights of the individual on the one hand and the sovereignty of the total social collective on the other. But it is not alive to the rich variety of intermediate or alternative associational groupings actually found in human cultures, nor is it prepared to ascribe to such groupings any rights not reducible either to the liberties of the citizen or to the prerogatives of the state. ${ }^{300}$

Anaya attributes Vattel with establishing "the foundation for the doctrine of state sovereignty, with its corollaries of exclusive jurisdiction, territorial integrity, and nonintervention in domestic affairs". ${ }^{301}$ Based as it was on European models of governance, Indigenous peoples were by definition excluded from statehood. ${ }^{302}$ Anaya observes the exclusive nature of Vattel's definition of statehood:

The concept of the nation-state in the post-Westphalian sense is based upon European models of political and social organization whose dominant defining characteristics are exclusivity of territorial domain and hierarchical, centralized authority. By contrast, indigenous peoples of the Western

\footnotetext{
299 Ibid.

${ }^{300}$ Ibid.

${ }^{301}$ Ibid at 21 .

${ }^{302}$ Ibid at 22.
} 
Hemisphere and elsewhere, at least prior to European contact, typically have been organized primarily by tribal or kinship ties, have had decentralized political structures often linked in confederation, and have enjoyed shared or overlapping spheres of territorial control. ${ }^{303}$

Europeans thereby constructed the self-affirming theoretical underpinnings of sovereignty in a manner that, from the outset, excluded Indigenous peoples from participating in the development of international law.

\subsubsection{The Marshall Trilogy}

Theory was transformed into law by a trilogy of cases that came before Chief Justice Marshall of the United States Supreme Court in the mid-19 $9^{\text {th }}$ century. These three cases shaped American and European notions of sovereignty while providing legal justification of their rights to colonial conquest. ${ }^{304}$ In Johnson v M'Intosh (1823), Chief Justice Marshall concluded that the colonists obtained title to the land simply through its "discovery" and that the "Indians" were left with only a right of occupancy. ${ }^{305}$ Barker describes the impact of the case as follows:

... the doctrine [of discovery] established that American Indians were not the full sovereigns of the lands that they possessed but were rather the users of the lands that they roamed and wandered over for purpose of shelter and sustenance. ... While it was accepted that Indians maintained particular rights associated with their status as the original inhabitants of the land, the exclusive rights of property in the land belonged to the nation who discovered the lands. Discovery was demonstrated by the appropriation for agriculture. $^{306}$

Barker observes how this self-affirming rationalization of colonialism became legal precedent as "Marshall invoked [the doctrine of discovery] as though it were a well-

\footnotetext{
303 Ibid.

${ }^{304}$ RO Porter, supra note 10 at 151; Anaya (2004), supra note 10 at 23; J Barker (2005), supra note 267 at 14.

${ }^{305}$ Johnson v M'Intosh, 21 US (8 Wheat) 543 (1823) as cited in J Barker (2005), supra note 267 at 6.

${ }^{306}$ J Barker (2005), ibid at 7-8.
} 
founded legal principle of international law."307 It was then integrated into American and European policy as if it were an unassailable fact.

In Cherokee Nation v Georgia (1831), Marshall characterized Indigenous populations as "domestic dependent nations" and likened their relationship with the United States government as that of ward and guardian. ${ }^{308}$ The decision had the effect of making "Indian tribes" a domestic concern and severed the link between Indigenous peoples and international law along with any presupposed or theoretical rights Indigenous peoples may have had to "treaties, nationhood, sovereignty, territorial integrity, and jurisdiction". 309

In Worcester v Georgia (1832), Chief Justice Marshall further elaborated upon the doctrine of discovery to establish that the United States government had full authority over the lands and the people within its territory. ${ }^{310}$ Notably, Chief Justice Marshall pointed to the Cherokee's treaties with the United States as evidence that the Cherokee recognized the sovereign authority of the United States. ${ }^{311}$

This trilogy of cases marked the first legal treatment of sovereignty and was quickly incorporated into European policy in Canada, New Zealand and Australia. ${ }^{312}$ Barker observes:

The entire self-fulfilling narrative of legal, moral and social superiority offered in such claims to doctrine as Marshall's discovery reinvented a sovereignty for indigenous peoples that was void of any of the associated rights to self-government, territorial integrity, and cultural autonomy that would have been affiliated with it in international law at the time. ${ }^{313}$

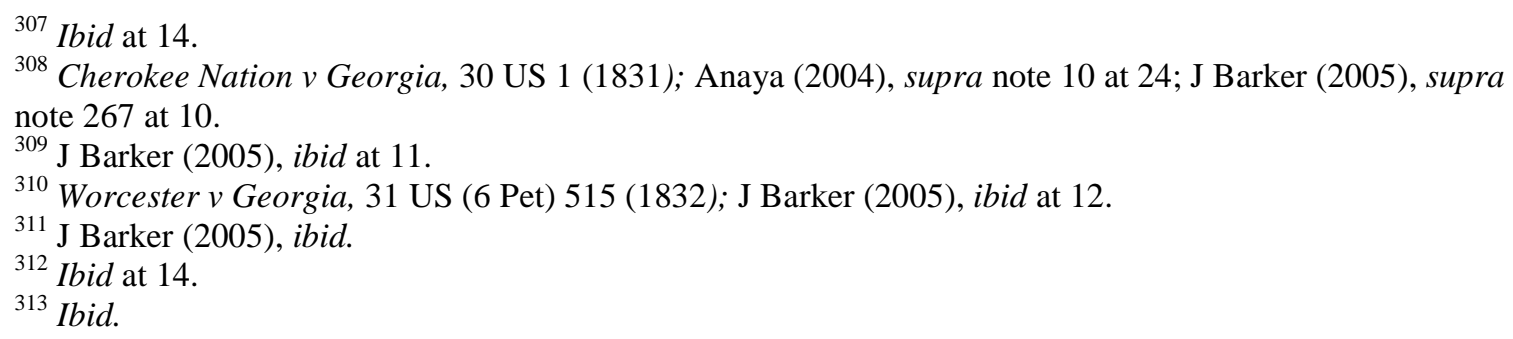


The Marshall trilogy therefore marked the end of any consideration of Indigenous

peoples as nations under international law. Anaya points to several assumptions of the

positivist school of thought that contributed to the legitimization of colonialism as a legal

right.

The first premise ... that international law is concerned only with the rights and duties of states. ... A second and related premise ... that international law upholds the exclusive sovereignty of states, which are presumed to be equal and independent, and thus guards the exercise of that sovereignty from outside interference. ... a third premise at the core of the positivist school was that international law is law between and not above states, finding its theoretical basis in their consent. And a fourth premise ... was that states that make international law and possess rights and duties under it make up a limited universe that excludes a priori indigenous peoples outside the mold of European civilization. ${ }^{314}$

International law quickly evolved to reinforce European entitlement to conquest and negate Indigenous rights to sovereignty. ${ }^{315}$ Harris observes that "[c]onflict over territory lies at the heart of colonialism." ${ }^{316}$ By extension, conflict over territory also lies at the heart of Western notions of sovereignty.

\subsubsection{Limits of Sovereignty}

Today the doctrine of sovereignty remains a foundational pillar of international law. ${ }^{317}$ However, there is also increasing recognition of the limits of sovereignty in light of human rights offences. Robert Odawi Porter points to the atrocities of the first and second World Wars as marking a new era in international commitment to protect human rights. $^{318}$

\footnotetext{
${ }^{314}$ Anaya (2004), supra note 10 at 26.

315 Ibid at 28 and 34; J Barker (2005), supra note 267 at 5.

${ }^{316}$ Harris, supra note 296 at 9.

${ }^{317}$ Thorson, supra note 7 at 513.

${ }^{318}$ RO Porter, supra note 10 at 3.
} 
Global consensus began to emerge that there was a limit to state sovereignty. To the extent that individual human rights might be violated by the actions of a particular state, there evolved a belief that it was appropriate and necessary as a matter of international law that other nations be allowed to interfere in a state's internal affairs. ${ }^{319}$

Porter also points to globalism as operating to erode a nation's territorial integrity and authority. He observes that "[i]n an era of modern commerce, communications, and technology, the notion that there is a "sovereign" territory impervious to influence by other nations has become increasingly absurd." ${ }^{320}$ However, Alfred \& Corntassel caution that globalization is also another form of empire building that operates to limit indigenous autonomy. ${ }^{321}$

\subsection{Indigenous Sovereignty}

We must begin to say the 'S' word. ${ }^{322}$

Dr. Harold Cardinal, Cree writer, political leader, teacher, and lawyer

The concept of 'Indigenous sovereignty' is still in its infancy. As an emerging and dynamic social construct, it is bound to evolve over time. Indigenous sovereignty is referred to loosely as "self-sufficiency",323 " "autonomy"324, "the most basic right of people to govern themselves without undue influence" ${ }^{325}$ or the right to "self-determination",326,

\footnotetext{
319 Ibid.

${ }^{320}$ Ibid at 4.

${ }^{321}$ Alfred \& Corntassel, supra note 10 at 601.

${ }^{322}$ Harold Cardinal, Address at the First Nations House of Learning, University of British Columbia (1995) as quoted in McCue, supra note 271 at 20 n5.

${ }^{323}$ Frank John King III, "The Myths Surrounding the Term 'Sovereign'” Indian Country Today (19 January 2000) A5, reprinted in RO Porter, supra note 10, 58-59 at 58 [King].

${ }^{324}$ RO Porter, supra note 10 at 231.

${ }^{325}$ Charles A Gourd, "Making a Name for Ourselves: The United Nations Draft Statement on the Rights of Indigenous Peoples" (1999) 7 Tulsa J of Comp and Int'1 L. 121, reprinted in Robert Odawi Porter, ed, Sovereignty, Colonialism and the Indigenous Nations: A Reader (North Carolina: California Academic Press, 2005) 705 at 705 [Gourd].

${ }^{326}$ Corntassel \& Primeau, supra note 10 at 72.
} 
although the latter term is mired in complexity given its association with Western legal rhetoric. ${ }^{327}$ According to McCue, "[t]he meaning of sovereignty has yet to undergo significant Indigenous and political treatment, definition and elaboration...". ${ }^{328}$ Yet, there is also a growing recognition that the development of a unified strategy regarding sovereignty is critical to Indigenous peoples' survival. ${ }^{329}$

According to Mohawk, there are currently two dominant views of thought regarding Indigenous sovereignty. One holds that "Indian sovereignty" ${ }^{330}$ was created by US Chief Justice John Marshall about 150 years ago. The other holds that Indigenous sovereignty existed long before colonisation. Mohawk characterizes the viewpoints as follows:

These two approaches, or points of view, have tended to divide people into two camps. In one camp, the U.S. legal definition is what is important. As these people see it, the pragmatic thing is to approach the subject as a topic (or subtopic) of U.S. law, and to seek answers for a definition of Indian nation sovereignty in court decisions and statute laws.

On the other side of the coin, there are Indian nationalists of many persuasions who feel that U.S. law or Canadian law do not define Indian sovereignty, that this sovereignty existed previously and under its own definitions. ${ }^{331}$

RO Porter observes that, at its core, there is general consensus that Indigenous sovereignty "rests upon the right of Indigenous peoples to define and carry out an existence separate and apart from other peoples." ${ }^{332}$ Beyond that, however, Indigenous interpretations of sovereignty diverge and cover the whole range of political perspectives from ultra-nationalists asserting absolute autonomy to neo-colonists promoting

${ }^{327}$ Ibid at 68-69.

${ }^{328} \mathrm{McCue}$, supra note 271 at 19.

${ }^{329}$ RO Porter, supra note 10 at 503.

${ }^{330}$ Mohawk, supra note 286 at 138.

${ }^{331}$ Mohawk, supra note 286 at 138.

${ }^{332}$ RO Porter, supra note 10 at 231. 
assimilation. ${ }^{333}$ Some scholars have suggested that discussion of Indigenous sovereignty

has lost its meaning within the sea of disparate opinions on the subject. ${ }^{334}$ However, Barker observes that within the diversity of Indigenous interpretations of sovereignty there are valuable insights to be learned about the nature of Indigenous identity. She states:

In the historical complexities and cultural richness and diversity of these and all indigenous communities is the truth of the heterogeneity of indigenous identity, not only in how indigenous peoples identify themselves and their cultures but in how their self-definitions inform the character of their unique political perspectives, agendas and strategies for sovereignty. ${ }^{335}$

Plurality emerges as a theme and key insight into Indigenous understandings of sovereignty and becomes a counterpoint to the "narrow fiction of a single sovereignty",336 which has historically operated to negate Indigenous identity.

The spectrum of perspectives on sovereignty poses unique challenges to a literature review of the subject. I have attempted to present these perspectives thematically while also remaining conscious of the potential of an unintended colonising effect that might result by over-simplifying these perspectives or trying to categorize them. With that in mind, I have loosely divided my literature review into three broad sections:

1. Sovereignty, Identity \& Indigenous Epistemologies - In this section, I review perspectives on Indigenous ways of knowing and explore the inextricable link between identity and sovereignty.

2. Asserting Sovereignty - In this section, I review some Indigenous perspectives of sovereignty within the Western legal framework both in terms of defining and

\footnotetext{
${ }^{333}$ Ibid.

${ }^{334}$ RO Porter, supra note 10 at xix.

335 J Barker (2005), supra note 267 at 17 [emphasis added].

336 Alfred (2005), supra note 40 at 33.
} 
asserting sovereignty as well as considering Indigenous concerns about the potential for "auto-colonization". 337

3. Transcending Sovereignty - In this section, I review several Indigenous scholars who assert that discussions of sovereignty are no longer useful to Indigenous struggles and that Indigenous scholarship and action must transcend current Western legal frameworks.

Ultimately, these three sections are illustrative of key strategies in the struggle for Indigenous peoples' emancipation and survival. At their root, all of these intellectual approaches are aimed at the common purpose of redefining Indigenous-settler relations. $^{338}$

RO Porter observes that the term sovereignty can be utilized for both offensive and defensive purposes. ${ }^{339}$ Internationally recognized states regularly assert sovereignty to enforce their territorial integrity, dominance and control over their land and resources. However, RO Porter asserts that, "as used by Indigenous peoples, the term serves instead as a basis for promoting the establishment of consensual, rather than unilateral, assertions of state authority within their territories."

\footnotetext{
${ }^{337}$ RO Porter, supra note 10 at 503.

${ }^{338}$ Ibid at xxi.

${ }^{339}$ Ibid at 4. Porter goes on to state, "In some respects, the use of the term dovetails with the concerns of nationalists in the international realm to, as they see it, protect their nations from foreigners. But as used by Indigenous peoples, the term serves instead as a basis for promoting the establishment of consensual, rather than unilateral, assertions of state authority within their territory."

${ }^{340}$ Ibid.
} 


\subsubsection{Sovereignty, Identity and Indigenous Epistemologies}

Our creation stories are one of our sources of sovereignty.

June McCue, Ned'u'ten ${ }^{341}$

Indigenous perspectives regarding sovereignty and self-determination are inherently different from those arising from within the Western classical tradition. ${ }^{342}$ Rather than accept the Western legal definition of the term, many Indigenous scholars have started to explore what Indigenous sovereignty means within Indigenous culture and epistemology. There are inherent barriers to trying to articulate Indigenous ways of understanding in an English literature review. As McCue notes, "Indigenous understandings of sovereignty are best articulated and transmitted in the languages of the Indigenous peoples." ${ }^{343}$ Fairbanks also emphasizes the link between language and sovereignty and asserts that the loss of language is ultimately a loss of sovereignty. ${ }^{344}$ The importance of language to understanding epistemology is well respected in Western classical traditions. Students of philosophy have for centuries undertaken to learn Latin or Greek in order to better understand the teachings of great Western philosophers with the recognition that meaning is inevitably lost in translation. Likewise, the nuances of Indigenous notions of sovereignty are inextricably linked to the language of the elders who still carry ancient wisdom in the form of stories. As a non-Indigenous person who does not know any Indigenous languages, I readily concede that this review of Indigenous scholarship can only skim the surface of Indigenous understandings of the subject.

${ }^{341}$ McCue, supra note 271 at 19.

${ }^{342}$ Ibid.

${ }^{343}$ Ibid at 20-21.

${ }^{344}$ Robert A Fairbanks, "Native American Sovereignty and Treaty Rights: Are They Historical Illusions?" (1996) 20 Amer Ind L Rev 141, reprinted in RO Porter, supra note 10, 60 at 63. 
Sovereignty, as a social construct, is ultimately a reflection of a group's values regarding their place within the world and their relationship with others. As a culturally derived construct, an understanding of sovereignty must begin with a respect for the values and epistemologies underlying Indigenous culture and identity. Different perspectives of sovereignty can ultimately be traced to divergent cultural and philosophical approaches to power. Alfred contends:

Nowhere is the contrast between indigenous and (dominant) Western traditions sharper than in their philosophical approaches to the fundamental issues of power and nature. In indigenous philosophies, power flows from respect for nature and the natural order. In the dominant Western philosophy, power derives from coercion and artiface - in effect, alienation from nature. ${ }^{345}$

McCue echoes this sentiment and draw a distinction between power and force:

From an indigenous perspective, sovereignty is not just human-centred and hierarchical; it is not solely born or sustained through brute force. Indigenous sovereignty must be birthed through a genuine effort to establish peace, respect and balance in this world. ${ }^{346}$

Indigenous notions of sovereignty, then, are not based in authority or domination over land but rather derived through balance and harmony with the natural environment.

Cheyfitz observes that a wide range of Indigenous cultures emphasize the importance of kinship with the natural world.

... the fundamental Western opposition of nature/culture is not a category of Native thinking because extended kinship incorporates the universe into the social and thus conserves it with the same care that one practices with all one's relatives. $^{347}$

\footnotetext{
${ }^{345}$ Taiaiake Alfred, "Sovereignty: An Inappropriate Concept" (1999) excerpt from Peace, Power, Righteousness: An Indigenous Manifesto (Oxford: Oxford University Press Canada, 1999) as reprinted in RO Porter, supra note 10 at 67 [Alfred (1999)].

${ }^{346}$ McCue, supra note 271 at 25.

${ }^{347}$ Eric Cheyfitz, "What is a Just Society? Native American Philosophies and the Limits of Capitalism's Imagination: A Brief Manifesto" in Eric Cheyfitz, N Bruce Duthu, \& Shari M Huhndorf, eds (Spring 2011) 110:2 S Atl Quart (Special Issue: Sovereignty, Indigeneity, and the Law) 291.
} 
Groenfeldt notes that Western worldviews tend to characterize the environment purely as a resource, a form of property, which can and should be valued within an economic perspective of the world. ${ }^{348}$ Christie asserts that an appreciation of Indigenous relationships with the natural world is central to understanding the nature of conflict between Indigenous and Western modes of thought.

Aboriginal visions of land are often, however, of a different order. The vision of land as a partner in a relationship - if the land is treated properly, with appropriate respect, it provides for people. People accommodate their behaviour to the social fabric built into the land and its spirits, with the understanding that humans are a part of this land and the larger social fabric and are thereby obligated to live according to the principles and rules that maintain the societal order and harmony. ${ }^{349}$

Alfred also emphasizes the central importance of this "partnership principle" ${ }^{350}$ to understanding indigenous sovereignty:

Indigenous philosophies are premised on the belief that the human relationship to the earth is primarily one of partnership. ... The partnership principle, reflecting a spiritual connection with the land established by the Creator, gives human beings special responsibilities within the areas they occupy, linking them in a natural and sacred way to their territories. ${ }^{351}$

This 'partnership principle' can be characterized as a pillar of Indigenous philosophical thought, which informs traditional Indigenous ideals about the markers of successful nationhood. Mezey asserts “... ancient teachings inform Indians that the true mark of a civilization is its ability to live in a location with a minimum disruption to its features." 352 The conflict between the Western settler states and Indigenous nations then, is therefore not a competition over resources as many Westerners perceive it to be but rather a

\footnotetext{
${ }^{348}$ Groenfeldt (2006), supra note 262.

${ }^{349}$ Christie, supra note 250 at 49.

${ }^{350}$ Alfred (2005), supra note 40 at 45.

${ }^{351} \mathrm{Ibid}$.

${ }^{352}$ Naomi Mezey, "The Distribution of Wealth, Sovereignty, and Culture through Indian Gaming" (1996) 48 Stan L Rev 711, reprinted in RO Porter, supra note 10, 414 at 423.
} 
conflict of ideals stemming from divergent beliefs about humanity's relationship to the land and what it means to be 'civilized'.

Christie cites Joy Harjo of the Creek people, for her insights into Indigenous relationships with the natural world.

All landscapes have a history, much the same as people exist within cultures, even tribes. There are distinct voices, languages that belong to particular areas. There are voices inside rocks, shallow washes, shifting skies; they are not silent. And there is unseen swirl through the heavens, but other motion, subtle, unseen, like breathing. A motion, a sound, that if you allow your inner workings to stop long enough, moves into the places inside you that mirror a similar landscape; you too can see it, feel it, hear it, know it. ${ }^{353}$

The primacy of the 'inner world' is a central theme in Indigenous philosophy. In “Aboriginal Epistemology" (1995), Ermine explores the notion that the larger community is a physical manifestation of inner space and the wisdom gained from introspection. In this context, "inner space is that universe of being within each person that is synonymous with the soul, the spirit, the self or the being." 354 Ermine recognizes the role of language and culture to transmit the wisdom and teachings derived from explorations of the inner space:

The Old Ones had experienced totality, a wholeness, in inwardness, and effectively created a physical manifestation of the life force by creating community. In doing so, they empowered the people to become the 'culture' of accumulated knowledge. The community became paramount by virtue of its role as repository and incubator of total tribal knowledge in the form of custom and culture. ${ }^{355}$

Ermine states that a key insight to these teaching has been the interconnectedness of all of creation. This wisdom permeates language, culture, identity and understandings of sovereignty. Ermine contends that the pervasiveness of Western epistemology

\footnotetext{
353 Joy Harjo, Secrets from the Center of the World (1989), cited in Christie, supra note 250 at n60.

${ }^{354}$ Willie Ermine, “Aboriginal Epistemology" in Marie Ann Battiste \& Jean Barman, eds, First Nations Education in Canada: The Circle Unfolds (Vancouver: UBC Press, 1995) 101 at 103 [Ermine (1995)]. ${ }^{355}$ Ibid at 104-105.
} 
undermines and adversely impacts Indigenous epistemology, culture and identity by introducing a 'fragmentary self-world view'. Arguably, Western assumptions of sovereignty not only negate Indigenous peoples' access to land and resources in the outer world but also promote "the dogma of fragmentation" in the inner world, indelibly harming Indigenous peoples' “capacity for holism”, which is central to Indigenous epistemology. ${ }^{356}$ Ermine concludes that the teaching of holism is embedded within Indigenous languages and that it is only by engaging Indigenous languages that Indigenous epistemologies can be reclaimed. ${ }^{357}$ King clearly illustrates this point as he observes, "[t]here really is no word for sovereign in our Lakota language. The closest we have is Oyate or Nation which is closer to unity." 358

Deeply embedded cultural values such as the "partnership principle", 359 interconnectedness and the relevance of the "inner space" $" 360$ inform Indigenous relations with the environment and with other peoples. The notion of Indigenous sovereignty emerges from, and is inextricably linked to, Indigenous values, languages and identities. From this perspective, sovereignty is "inherent" or derived "from within a people or culture". ${ }^{361}$ Horse \& Lassiter define inherent sovereignty as follows:

Inherent sovereignty means having those rights like language and buffalo medicine, rights that form the very foundation of who we are as Kiowa people. Kiowas like myself hold these rights to be as self-evident and unalienable as those rights upon which the United States was originally founded. These are our rights to life, liberty and the pursuit of happiness. ${ }^{362}$

\footnotetext{
${ }^{356}$ Ibid at 110 .

357 Ibid.

${ }^{358}$ King, supra note 323 at 59.

${ }^{359}$ Alfred (2005), supra note 40 at 45.

${ }^{360}$ Ermine (1995), supra note 354 at 103.

$361 \mathrm{~J}$ Barker (2005), supra note 267 at 19-20.

362 Billy Evans Horse \& Luke E. Lassiter, “A Tribal Chair's Perspective on Inherent Sovereignty” (1997)

10 St. Thomas L. Rev 79, reprinted in RO Porter, supra note 10, 30 at 33.
} 
Similarly, Harjo asserts, “... sovereignty is about our histories, our languages, our religions, our elders, our ancestors, our children, our future, nationhood."363

As with Western classical traditions, Indigenous ideas about sovereignty are often understood in religious or spiritual terms. The Nuxalk Nation declares that their sovereign powers are derived from the Creator.

Their Aboriginal Title and Right to self-determination are confirmed and strengthened by their understanding that sovereign powers [are] vested in them by the Creator. The Nuxalk territorial lands, waters, air and all its natural resources were given to the Nuxalk people by the Creator to provide for their essential needs. ${ }^{364}$

Indigenous creation stories and mythology are important to understanding Indigenous sovereignty. ${ }^{365}$ Davis points to the many Indigenous traditions that believe that the earth itself exists only because "it is breathed into being by human consciousness"366 and that many Indigenous peoples believe that it is their sacred responsibility to act as guardians to the natural world. Sovereignty is defined in terms of one's duties to the land rather than rights to exploit the land. ${ }^{367}$ Indigenous rituals, sacrifice and rites of passage then reinforce this sacred relationship between the human, spiritual and natural worlds. ${ }^{368}$ Indigenous scholar, teacher and poet, Peter Cole illustrates this interconnectedness (best read aloud):

\footnotetext{
${ }^{363}$ Suzan Shown Harjo, "In Defense of Native Sovereignty; Indian Advocacy in the American Body Politic" (1998) 15:2 Native Americas reprinted in RO Porter, supra note 10, 659 at 659.

${ }^{364}$ Nuxalk Nation, "Statement before the United Nations Working Group in Indigenous Populations, July 31, 1984" (Fourth World Documentation Project, 1997), reprinted in RO Porter, supra note 10, 679 at 679680 [Nuxalk Nation].

${ }^{365}$ McCue, supra note 271 at 19.

${ }^{366}$ Wade Davis, "Dreams From Endangered Cultures" (Lecture presented to TED, February 2003), online: TED < http://www.ted.com/talks/lang/eng/wade davis_on_endangered_cultures.html> [Davis (2003)].

${ }^{367}$ Lil'wat Nation, Mount Currie Band Council, "Introduction and Application for Membership into the International League of United Nations (Fourth World Documentation Project, 1997)" in RO Porter, supra note 10,677 at 677-679 [Lil'wat Nation].

${ }^{368}$ Wade Davis, "The Wayfinders: Why Ancient Wisdom Matters to the Modern World" (Lecture presented to Long Now Foundation, January 2010), online: Fora TV Conference Channel $<$ http://fora.tv/2010/01/13/Wade_Davis_Why_Ancient_Wisdom_Matters_in_the_Modern_World $>$ [Davis (2010)].
} 
as first peoples of this land our responsibilities include

to take into accountability not just measurability

our relationships with the rest of creation

we follow our original instructions as orally passed on

as well as continually relearned in our ceremonies rituals daily protocols

we work to regenerate mutual relationships interpenetrating considerations

ethics is not an add-on or a form to fill in

it is intimate integration with the deep structure of our understanding

of creation including its ongoingness its pre- co- and post-emptiveness ...

do we dare move a stone knowing that it has a spirit

knowing it has been $\mathrm{t} /$ here a thousand millennia

do we dare dig into our mother the earth our earth the mother

even with our hands even with our thoughts our metaphors

and not remember we are all related ${ }^{369}$

Groenfeldt contends that many of the conflicts between Indigenous peoples and Western

forces can be traced back to the Western world's negation of Indigenous spirituality

through its preoccupation with economic development. In this way, conflict is borne out

of the domination of Western values over Indigenous values.

McCue cautions that European-derived notions of power, sovereignty and

colonialism operate at the "expense of human and ecological diversity." 370 Groenfeldt

argues that Indigenous value systems must be preserved to ensure "value diversity" and

provide alternatives to Western culture as it becomes increasingly apparent that the

Western economic value system is unable to cope with the growing litany of problems

that confront the world. ${ }^{371}$ Davis similarly calls for the protection and preservation of

the world's "ethnosphere", the cultural equivalent to the biosphere which he defines as

"the sum total of all thought and dreams, myths, ideas, inspirations, intuitions, brought

into being by the human imagination since the dawn of consciousness". Davis asserts, "it

is not change or technology that threatens the integrity of the ethnosphere. It is power:

\footnotetext{
${ }^{369}$ Peter Cole, "Aboriginalizing methodology: Considering the canoe" (2002) 15:4 Qualitative Studies in Education 447 at 457, cited in Umpleby, supra note 54 at 457.

${ }^{370}$ McCue, supra note 271 at 28.

${ }^{371}$ Groenfeldt (2006), supra note 262 at 9.
} 
the crude face of domination." 372 As Alfred observes, "Indigenous perspectives offer alternatives, beginning with the restoration of a regime of respect." 373

The intellectual struggle to develop a unified strategy around sovereignty can be seen as a key part of a larger battle for Indigenous emancipation; to be free from domination - from a political perspective but also from an intellectual and cultural perspective. RO Porter contends that the battle being fought over sovereignty is essential to the survival of Indigenous peoples:

From my perspective, sovereignty is the fundamental basis for the existence of Indigenous societies. This perspective is rooted in the view that without such autonomy, there is no long term ability to shape one's own destiny, and thus no way to live a distinct existence. ${ }^{374}$

To the extent that institutions built upon Western notions of sovereignty continue to propagate the domination, control and exploitation of land, resources and people, then Western classical sovereignty is arguably a weapon in an ongoing "ethnocide",375 and assimilation of peoples through its implicit negation of Indigenous values and culture.

A review of the literature suggests that inherent Indigenous sovereignty is derived from culture, language, religion, values and identity. Vine Deloria asserts that Indigenous sovereignty consists "more of continued cultural integrity than of political powers and to the degree that a nation loses its sense of cultural identity, to that degree it suffers a loss of sovereignty ${ }^{\text {376 }}$ However, Corntassel \& Primeau argue that expanding the concept of sovereignty to include cultural integrity simply complicates the debate and

${ }^{372}$ Davis (2003), supra note 366 at 15:05.

${ }^{373}$ Alfred (2005), supra note 40 at 46.

${ }^{374}$ RO Porter, supra note 10 at 231.

${ }^{375}$ Davis (2003), supra note 366 at 16:20.

${ }^{376}$ Vine Deloria, Jr, "Self-Determination and the Concept of Sovereignty" in Roxanne Dunbar Ortiz, ed, Economic Development in American Indian Reservations (New Mexico: University of New Mexico, 1979) 22, reprinted in RO Porter, supra note 10, 52 at 54. 
"serves to dilute the meaning of sovereignty in international law." "377 They also note Indigenous peoples' right to preserve their cultural integrity is already enshrined in international law. The debate may therefore be reduced to one of semantics.

Regardless, of how inherent Indigenous sovereignty ultimately informs strategies within international legal discourse, valuing the plurality of unique expressions of Indigenous sovereignty is nevertheless an important step in reclaiming Indigenous epistemology and preserving Indigenous values. ${ }^{378}$ Barker observes that Shawnee scholar, Glenn T. Morris, Mohawk scholar Taiaiake Alfred and other Indigenous theorists are calling for the advancement of "intellectual sovereignty" as an emerging field of inquiry aimed at de-colonizing Indigenous epistemologies of law and methodological perspectives by moving beyond "the colonial legacies of concepts like sovereignty and nationhood."379 This can best be achieved by returning to Indigenous epistemologies and languages and disengaging completely from the dominant legal discourse regarding sovereignty. In stark contrast to this intellectual approach, other Indigenous activists and scholars continue to pursue their autonomy and assert their claims for sovereignty within the dominant Western framework.

\subsubsection{Asserting Sovereignty}

The majority of Indigenous scholars and activists to date have engaged sovereignty from a political and legal struggle rather than an epistemological one. This section reviews Indigenous perspectives regarding the quest for autonomy by asserting the existence of sovereignty in a manner consistent with Western colonial rhetoric. Anaya identifies two primary arguments for claims to Indigenous sovereignty. One he calls the

377 Corntassel \& Primeau, supra note 10 at 71.

378 J Barker (2005), supra note 267 at 25.

${ }^{379}$ Ibid at 24-25. 
"historical sovereignty approach" while the other involves pursuing rights of self-

determination within the lexicon of human rights law (human rights approach). ${ }^{380}$ This section will consider only the former approach. Anaya characterizes the "historical sovereignty approach" as follows:

Under this approach, self-determination is invoked to restore the asserted "sovereignty" of an historical community that roughly corresponds to the contemporary claimant group. This approach generally accepts the premise of Western theoretical origins of a world divided into territorially defined, independent or "sovereign" states. However, this approach perceives an alternative and competing political geography based on an assessment of historically based communities. ${ }^{381}$

The aspiration of most of the world's Indigenous peoples has been to establish their autonomy "within the framework of existing states.",382

Western conceptions of sovereignty are most often correlated with autonomy ${ }^{383}$, power, ${ }^{384}$ control, ${ }^{385}$ authority, ${ }^{386}$ and self-governance ${ }^{387}$. RO Porter defines sovereignty with reference to European norms regarding the law of nations.

"Sovereignty" is, after all, an English word referring to the power of a particular nation to exercise governmental authority over a particular territory. It is a classic term of European international law referring to the absolute and inviolate power of a nation to manage generally its own affairs and, in particular, its internal affairs. ${ }^{388}$

\footnotetext{
${ }^{380}$ S James Anaya, "The Capacity of International Law to Advance Ethnic or Nationality Rights Claims" (1990) 75 Iowa LRev 837 as reprinted in RO Porter, supra note 10, 681 at 684 [Anaya (1990)].

${ }^{381}$ Ibid at 682-683 [emphasis added].

${ }^{382}$ Akwesasne Notes, supra note 10 at 715 [emphasis added].

${ }^{383}$ RO Porter, supra note 10 at 231.

${ }^{384}$ RO Porter, supra note 10 at 3.

${ }^{385}$ Christie, supra note 250 at 28.

${ }^{386}$ RO Porter, supra note 10 at 3.

${ }^{387}$ Gourd, supra note 325 at 705.

${ }^{388}$ RO Porter, supra note 10 at 3 . However, the etymology of the word sovereignty derives from a French word. According to the Online Etymology Dictionary it is "from Anglo-Fr. sovereynete, from O.Fr. souverainete, from soverain (see sovereign), meaning "authority, rule" and is recorded from late 14c.; sense of "existence as an independent state" is from 1715." See Online Etymology Dictionary <http://www.etymonline.com/index.php?term=sovereignty>.
} 
Ultimately, sovereignty refers to decision-making authority regarding a discrete geographic area. Christie defines Indigenous sovereignty as follows:

The appropriate definition of Aboriginal sovereignty, then, must aspire to capture the essential notion of linkages between political (i.e. decisionmaking) communities and discrete tracts of land. For the purposes of this project Aboriginal sovereignty can describe (a) the ability of an Aboriginal nation to control and exercise the processes that go into the ongoing project of establishing and maintaining a collective identity and (b) the ability of this nation to use this collective self-identity to make decisions regarding how its people, collectively and individually, relate to its territory. ${ }^{389}$

Within international law, the test of sovereignty is evidenced, in part, by a nation's ability to enter into agreements with other nation states. Gourd sets out the internationally accepted criteria for sovereignty as follows:

Sovereignty, at a minimum, is the right to self-government. In addition, a group must meet a set of internationally accepted criteria to possess all the attributes of sovereignty:

(1) A group must have citizens

(2) The group must have territory over which the government has civil and criminal jurisdictional authority;

(3) The group must have a process to establish public policy (...)

(4) The capacity to enter into foreign relations. That government, then, must have relationships with other "recognized governments". 390

Many Indigenous scholars point to treaties and the treaty making process as evidence that settler states expressly recognized Indigenous peoples' pre-existing sovereignty.

Foreign relations and the existence or lack of existence of treaties between settlers and Indigenous peoples has become central in assertions of Indigenous sovereignty. On the one hand, scholars assert that settlers expressly recognized Indigenous peoples' preexisting sovereignty through extensive treaties, complex trading agreements and express recognition of Indigenous rights to occupancy. ${ }^{391}$ On the other hand, other Indigenous peoples have pointed to the lack of treaties in many cases to demonstrate that there has

\footnotetext{
${ }^{389}$ Christie, supra note 250 at 26-27.

${ }^{390}$ Gourd, supra note 325 at 706.

${ }^{391}$ Oneida Indian Nation of New York, "Sovereignty Statement", online: Oneida Indian Nation $<$ http://oneida-nation.net/sovdoc.html $>$, reprinted in RO Porter, supra note 10, 27 at 27 [Oneida Indian Nation]; Corntassel \& Primeau, supra note 10 at 66; J Barker (2005), supra note 267 at 4.
} 
never been any cessation of land or implied forfeit of sovereignty. Both of these approaches to asserting historical sovereignty face legal limitations and practical challenges.

\section{a) Prior Sovereignty as Evidenced by Treaty Making Process}

The treaty making process is taken as de facto evidence that colonial powers recognized the existing sovereignty of Indigenous nations. Corntassel \& Primeau consider the strategy of using the treaty-making process as a means to assert "prior" sovereignty $^{392}$.

"Prior sovereignty" refers to the argument that antecedent to the invasion of the North American continent by the European powers, Indian communities exercised sovereignty over themselves and that, at least in the initial stages of contact, this sovereignty was formally recognized by the colonial powers via the treaty-making process. ${ }^{393}$

Barker notes that the issues of territorial boundaries and jurisdiction were the primary subjects of such treaties. ${ }^{394}$ Oneida argues that Europeans recognized sovereignty of Indigenous populations within their own legal framework when they entered into treaties, established trading relationships and recognized "Indian right of occupancy". 395 This approach can utilize the vast and documented history of Indigenous-colonist relations to support an argument for pre-existing Indigenous sovereignty.

However, Corntassel \& Primeau caution that there are problems with this approach. First, they note that the argument is flawed to the extent that it relies upon treaty making as evidence of the international community's collective acknowledgement of Indigenous peoples' prior sovereignty. The authors cite the maxim pacta sunt

\footnotetext{
392 Corntassel \& Primeau, ibid.

393 Ibid.

${ }^{394} \mathrm{~J}$ Barker (2005), supra note 267 at 4.

395 Oneida Indian Nation, supra note 391 at 27.
} 
servanda, ${ }^{396}$ which underlies all treaty law and refers to the obligation of parties to a treaty to carry out the terms of the treaty as binding and perform their obligations in good faith. ${ }^{397}$ If the international community sincerely recognized the legal force of treaty making and the prior sovereignty of Indigenous peoples, then there should have been some outrage or consequence in light of the settlers' repeated failure to honour those treaties. There was not.

The lack of response on the part of the international community to the abrogation of these treaties should speak volumes as to the status of indigenous populations within the Community of "civilized" nations at that time.

The fact that pacta sunt servanda was not adhered to by the colonial powers in their dealings with indigenous groups does much to undermine the central premise of the strategy advocating the "trail of broken treaties" as a means of reclaiming "prior sovereignty". 398

Secondly, Corntassel \& Primeau note that the prior sovereignty argument is not an inclusive one as there are a vast number of Indigenous groups that were not invited to participate in the treaty-making process. ${ }^{399}$ For many other Indigenous peoples', the process of treaty making became nothing more than a process of rubber-stamping their relocation to reserves. ${ }^{400}$ The authors conclude:

A treaty-based approach is legally questionable and ultimately has limited applicability - it addresses the situation of a small minority of the world's indigenous populations, and could only exacerbate an already nearly intractable state-centric system. ${ }^{401}$

Even where treaties do exist, there continues to be on-going disputes regarding their interpretation and enforceability.

\footnotetext{
${ }^{396}$ Latin for "agreements must be kept".

${ }^{397}$ Corntassel \& Primeau, supra note 10 at 68.

${ }^{398}$ Ibid.

${ }^{399} \mathrm{Ibid}$ at 63.

${ }^{400} \mathrm{Ibid}$ at 65.

${ }^{401}$ Ibid at 70.
} 


\section{b) Prior Sovereignty As Evidenced by Lack of Treaty}

There are also some Indigenous nations who can point to a long trail of historical documents asserting their nationhood and their legal right to sovereign control over their territories. In 1997, the Lil'wat Nation (also known as the Lillooet Tribe) sought membership into the United Nations asserting that "we have not signed any treaties or have not been conquered in warfare thus our title and rights to the land have not been extinguished." ${ }^{, 402}$ They also assert that the Canadian government does not represent their people nor is it able to speak on their behalf. In support of their application, the Lil'wat Nation attached "The Declaration of the Lillooet Tribe", signed by their Ancestral Chiefs on May $10^{\text {th }}, 1911$ which read:

\section{STATEMENT OF REAFFIRMATION OF THE 1911 LILLOOET TRIBAL DECLATION $^{403}$}

WE, THE SOVEREIGN STL'ATL'IMX NATION do in our name and the name of our fore-bearers affirm and reaffirm the May 10, 1911 Lillooet Declaration. We speak the truth, and we speak for our whole people from ancient time to the times yet uncounted.

WE, REAFFIRM that as a People we are the Rightful owners of our land which has been our home since time immemorial. It is our duty as a people to respect and live with our brothers the fish, bear, deer, wolf, raven, eagle, and the others among our brothers. We are bound by our Stl'atl'imx laws, to respect and live with the trees and other plants of our land. We are bound to protect and use well those things in nature which have been given in our trust.

WE REAFFIRM that as a People we have a duty to ourselves to protect, defend, comfort and care for the well-being of all our generations past, present and future. We declare that we are and intend to remain economically, culturally, socially, linguistically, spiritually, selfdetermined.

WE REAFFIRM that as a sovereign people, we are obligated to ensure only one system of government in our original title to Stl'atl'imx territory waters and resources. As a People, we accept the duty to ensure the common well being of our Nation and reaffirm our inherent right to govern ourselves in

\footnotetext{
${ }^{402}$ Lil'wat Nation, supra note 367 at 677 [emphasis added].

${ }^{403}$ Ibid at 678-679.
} 
accordance with our traditional institutions and customs and law in so doing, to promote and defend our right to survive as a People.

WE REAFFIRM that as a People we seek peaceful and friendly relations with our neighbours and peoples throughout the world. It is our duty to perfect all of our relations on the basis of sovereign equality.

IN THE NAME OF OUR GRANDFATHERS AND GENERATIONS OF STL'ATL'IMX YET UNBORN, WE DECLARE OUR SOLEMN COMMITMENT TO THESE PRINCIPLES AND TO WHATEVER COLLECTIVE ACTION MAY BE NEEDED TO DEFEND THEM. ${ }^{404}$

Notably, the Lil'wat Nation's declaration not only asserts sovereignty but also includes a corresponding description of the duties that a sovereign nation must abide by under Stl'atl'imx laws. Explicit in this declaration is the assertion that sovereignty is correlated with duties and obligations to the environment and peaceful relations with all people and all species.

In a letter dated August 25, 1910 to Sir Wilfrid Laurier, then Prime Minister of Canada, the Chiefs of the Shushwap, Okanagan and Couteau Tribes of British Columbia outlined the history of their relations with the white settlers and demanded justice be done.

[The whites] say there are no lines, except what they make. They have taken possession of all the Indian country and claim it as their own. Just the same as taking the "house" or "ranch" and, therefore, the life of every Indian tribe into their possession. They have never consulted us in any of these matters, nor made any agreement, "nor" signed "any" papers with us. They 'have stolen our lands and everything on them' and continue to use 'same' for their 'own' purposes. They treat us as less than children and allow us 'no say' in anything. They say the Indians know nothing, and own nothing, yet their power and wealth has come from our belongings. The queen's law which we believed guaranteed us our rights, the B.C. government has trampled underfoot. This is how our guests have treated us - the brothers we received hospitably in our house. ${ }^{405}$

\footnotetext{
404 Lil'wat Nation, supra note 367 at 677 [emphasis added].

405 Lillooet Tribal Council, ed, "Memorial: To Sir Wilfred Laurier, Premier of the Dominion of Canada From the Chiefs of the Shuswap, Okanagan and Couteau Tribes of British Columbia” V: VIII The St'át'imc Runner (T'ak I sts'úqwas'a/August 2010) 19 at 20.
} 
The Declaration of the Tahltan Tribe (October 18, 1910) also claims "the sovereign right to all the country of our tribes" on the basis that no agreement or treaty was ever made with their peoples. ${ }^{406}$ One hundred years later and there are still no treaties with these peoples. Instead, Indigenous peoples in British Columbia and elsewhere have endured and survived aggressive assimilation policies, which included forcibly removing children from their families and placing them in residential schools and prohibiting Indigenous languages and cultural practices. ${ }^{407}$ In this context, the evolution of Western sovereignty took place as one part of a comprehensive policy of ethnocide despite repeated and sophisticated appeals to justice.

\section{c) Limitations \& Challenges of the Historical Sovereignty Approach}

Despite the historical documentary evidence and appeals to justice, claims to sovereignty by Indigenous groups face major limitations to these arguments in international law. The doctrine of sovereignty is deeply embedded in international law and, even in an era of post-colonialism, recognition of new states is rare. Anaya asserts that claims for Indigenous autonomy within the historical sovereignty approach are limited by three principles of international law. ${ }^{408}$ First, the doctrine of intertemporal law requires that historical events be judged according to the law in effect at the time of their occurrence. This is problematic to the extent that the doctrines of conquest and effective occupation were accepted legal tools during the perpetuation of colonialism. Second, the principle of recognition in international law assumes a state's entitlement to sovereignty "when a preponderance of states, international organizations, and other

\footnotetext{
${ }^{406}$ Lillooet Tribal Council, ed, "Declaration of the Tahtlan Tribe October 18, 1910” V:X The St'át'imc Runner (Lhwál'tsten/October 2010) 24 at 24.

407 Umpleby, supra note 54 at 215-240.

408 Anaya (1990), supra note 380 at 682-683.
} 
relevant international actors recognize a state's boundaries and corresponding sovereignty over territory". 409 To the extent that the sovereignty of settler states is already recognized internationally there is no tendency to question whether the territory was lawfully acquired. Third, Anaya cites the "normative trend within international legal process toward stability through pragmatism over instability." ${ }^{410}$ Anaya asserts that together, these three limitations pose a potentially insurmountable barrier to claims for Indigenous sovereignty within international law.

In addition to the limitations set out be Anaya above, there are practical barriers in the pursuit of sovereignty, including (i) a peoples' capacity to govern themselves and (ii) the ever-present potential for assimilation.

i) Capacity for Governance

Indigenous sovereignty requires not only an assertion of sovereignty, but also the ability to act effectively in the capacity of a sovereign nation. RB Porter contends that Indigenous sovereignty is comprised of three facets: “(i) the degree to which Indians believe in the right to define their own future, (ii) the degree to which Indians have the ability to carry out those beliefs, and (iii) the degree to which tribal sovereign acts are recognized both within the tribe and by the outside world."411 RB Porter contends that the quest for sovereignty is limited by rampant tribal government dysfunction including "poor administration, dependence and infighting". ${ }^{412}$ Each of these factors impacts upon Indigenous peoples' ability to act with authority as a sovereign nation. The current challenges faced by Indigenous peoples to govern themselves are a direct result of years

\footnotetext{
409 Ibid at 682.

${ }^{410}$ Ibid at 683 [emphasis added].

${ }^{411}$ Robert B Porter, "Strengthening Tribal Sovereignty through Government Reform: What Are the Issues?” (Winter 1997) 7 Kan JL \& Pub Pol'y 72, reprinted in RO Porter, supra note 10, 55 \& 518 at 55. 412 Ibid.
} 
of cultural oppression living under colonial rule. Modern-day tribal governments have little resemblance to traditional Indigenous institutions and face the onerous task of uniting fragmented communities, which have endured years of aggressive assimilation:

Quite literally, if a tribal community is comprised of people who were raised in traditional way, speak the native language, and practice the traditional religion, then the tribal members who were educated in the missionary school, know little of the traditional culture, and live an assimilated lifestyle might as well be from another planet. It is hard to imagine a greater chasm of identity between people all professing to be living together in the same community. It is against this backdrop that tribal government must function. The mechanism set in place to channel the passion and power of our increasingly diverse communities - our governments - is wholly inadequate to meet the challenges of our modern tribal nations. ${ }^{413}$

Claims for Indigenous sovereignty can be undermined if effective and unified tribal governments do not accompany them. RB Porter contends that effective internal governance structures are a critical part of a strategic claim for sovereignty. This does not mean that Indigenous peoples need to agree all the time in order to be seen as effective, but he asserts that "we should be able to find a way for all of our members to agree as to the process by which we govern ourselves. Only when we have all of our people working together will be able to maximize our sovereign potential, and thus allow our future generations to survive." ${ }^{414}$ RB Porter places particular importance on the role of tribal laws and dispute resolution mechanisms to the realization of sovereignty:

... sovereignty means that the Indians themselves must resolve their own problems and manage their own affairs. The first step in that process is for Indian nations to realize that the tribal dispute resolution mechanism has everything to do with how tribal members interact with one another, how capable they are of working with each other on common endeavors, and thus, how strong their families, clans, communities, and nations will be. ${ }^{415}$

\footnotetext{
413 Ibid at 523.

${ }^{414}$ Ibid at 525.

${ }^{415}$ RB Porter "Peacemaking", supra note 56 at 563.
} 
Throughout this literature review, there has been surprisingly little attention paid to what sovereignty would actually look like given that Indigenous nations are situated within internationally recognized sovereign states. Christie provides several examples of what state-to-state relations sharing geographic territory could look like ${ }^{416}$ and several scholars provide insight into strategies for obtaining sovereignty but overall, there is very little attention paid to the pragmatics of governance when sovereignty is actually obtained. An emerging issue is whether the citizens of sovereign Indigenous nations would lose the protection of civil liberties embedded within the settler state's constitutions. ${ }^{417}$ The loss of constitutional rights such as the freedom of expression would be particularly threatening in communities divided by tribal family politics.

ii) Sovereignty and Auto-colonization

Perhaps the most provocative challenge to sovereignty claims predicated upon international law is the vocal criticism from Indigenous scholars and leaders that the perpetuation of Western legal concepts and institutions is a dangerous form of selfassimilation. RO Porter describes "auto-colonization" as "the process by which colonized people may adopt and engage in behaviors that are rooted in the policies of the colonizing nation but which are rationalized as one's own." ${ }^{, 418}$ Indigenous political leaders are also susceptible to corruption and neo-colonialism. According to Adams, neo-colonialism occurs when the privileged governing elite within an Indigenous nation

\footnotetext{
${ }^{416}$ Christie, supra note 250.

${ }^{417}$ See Chief Mountain v British Columbia (Attorney General) 2011 BCSC 1394 (Canada) in which the plaintiff claims that the Nisga'a Treaty is inconsistent with the Constitution of Canada.

${ }^{418}$ RO Porter, supra note 10 at 503.
} 
are given benefits by the settler state "in return for their help in pacifying the majority."419

Alfred contends that the quest for sovereignty is a red herring that merely leads to further integration with the colonial agenda. He argues that the state has created “incentives for integration" by offering token financial contributions and inconsequential measures of self-administration. ${ }^{420}$ Alfred asserts that Western concepts of power are ultimately incompatible with Indigenous epistemology and values, and cites Boldt \& Long for the proposition that the "endorsement of hierarchical authority and a ruling entity constitutes a complete rupture with traditional indigenous principles." ${ }^{421}$ Alfred observes:

Traditional indigenous nationhood stands in sharp contrast to the dominant understanding of "the state": there is no absolute authority, no coercive enforcement of decisions, no hierarchy, and no separate ruling entity. In accepting the idea that progress is attainable within the framework of the state, therefore, indigenous people are moving towards acceptance of forms of government that more closely resemble the state than traditional systems. $^{422}$

Alfred contends that a claim to sovereignty can unintentionally lead to Indigenous peoples framing their political goals with reference to Western ideals and "the common criteria of statehood - coercive force, control of territory, population numbers, international recognition - come to dominate discussion of Indigenous peoples' political goals as well." 423 The state readily exploits these "theoretical inconsistencies". ${ }^{424}$

\footnotetext{
${ }^{419}$ Howard Adams, "The Process of Neocolonialism, excerpt from Tortured People: The Politics of Colonization, Ch. 8 (Theytus Books, 1999) as reprinted in RO Porter, supra note 10, 497 at 499.

${ }^{420}$ Alfred (1999), supra note 345 at 71.

${ }^{421}$ Ibid at 67-68. Also see Corntassel \& Primeau, supra note 10 at 70-71, where the authors reference Boldt $\&$ Long for the proposition that a claim for sovereignty within the framework of colonial law "only further legitimizes Western-European power structures of authority and decision-making."

${ }^{422}$ Alfred (1999), supra note 345 at 68.

${ }^{423} \mathrm{Ibid}$, at 69.
} 
Alfred concludes that up till recently, sovereignty has been an effective vehicle for critiques of colonialism but that ultimately Indigenous emancipation is best served by undermining the "myth of state sovereignty". ${ }^{25}$

\title{
3.2.3 Transcending/Reclaiming Sovereignty
}

\author{
Sovereignty carries the horrible stench of colonialism. ${ }^{426}$ \\ Joanne Barker, Lenape
}

Alfred, Corntassel, Barker and others have strongly argued that the quest for sovereignty is not only inconsistent with Indigenous values but also a major obstacle in the struggle for decolonisation. ${ }^{427}$ These scholars contend that once you engage the epistemological roots of sovereignty it becomes apparent that there is no way to engage sovereignty without perpetuating the colonial machine. Correlated as it is with assumptions of entitlement, domination, hierarchical authority and control over territory, Western sovereignty undermines and effectively oppresses Indigenous epistemologies and traditional Indigenous relationships with the natural world. ${ }^{428}$ It operates to limit the way Indigenous peoples are able to think about themselves. ${ }^{429}$ Barker explains:

... translating indigenous epistemologies about law, governance, and culture through the discursive rubric of sovereignty was and is problematic. Sovereignty as a discourse is unable to capture fully the indigenous meanings, perspectives, and identities about law, governance, and culture,

\footnotetext{
${ }^{424}$ Ibid.

425 Ibid at 79.

${ }^{426} \mathrm{~J}$ Barker (2005), supra note 267 at 26.

${ }^{427}$ See Alfred (2005), supra note 40 at 41-42, in which the author states: "One of the main obstacles to achieving peaceful coexistence is of course the uncritical acceptance of the classic notion of sovereignty as the framework for discussions of political relations between peoples."

${ }^{428}$ See ibid at 48, where Anaya states, “... indigenous peoples have come to realize that the main obstacle to recovery from this near total dispossession ... is the dominance of European-derived ideas such as sovereignty."

${ }^{429}$ Ibid at 34-35.
} 
and thus over time it impacts how those epistemologies and perspectives are represented and understood."430

Indigenous identity then becomes defined in reaction to colonialism and the quest for sovereignty becomes a quest to be accommodated "within a 'legitimate' framework of settler state governance."431

Alfred cautions that it is dangerous to assume that sovereignty is an appropriate political objective or model for governance for Indigenous peoples. ${ }^{432}$

... sovereignty is an exclusionary concept rooted in an adversarial and coercive Western notion of power. Indigenous peoples can never match the awesome coercive force of the state; so long as sovereignty remains the goal of indigenous politics, therefore, Native communities will occupy a dependent and reactionary position relative to the state. Acceptance of "Aboriginal rights" in the context of state sovereignty represents the culmination of the white society's efforts to assimilate indigenous peoples. ${ }^{433}$

Alfred calls for a rejection of the concept of "indigenous sovereignty" and argues that "[t]he next phase of scholarship and activism ... will need to transcend the mentality that supports the colonization of indigenous nations...". ${ }^{434}$ He also calls upon people committed to transcending colonialism "to de-think the concept of sovereignty and replace it with a notion of power that has as its root a more appropriate premise." ${ }^{, 45}$

Alfred \& Corntassel assert that:

As Indigenous peoples, the way to recovering freedom and power and happiness is clear: it is time for each one of us to make the commitment to transcend colonialism as people, and for us to work together as peoples to become forces of Indigenous truth against the lie of colonialism. We do not need to wait for the colonizer to provide us with money or validate our vision of a free future; we only need to start to use our Indigenous languages

\footnotetext{
${ }^{430} \mathrm{~J}$ Barker (2005), supra note 267 at 19.

431 Alfred (2005), supra note 40 at 34-35.

432 Ibid at 38; Alfred (1999), supra note 345 at 68.

${ }^{433}$ Alfred (1999), ibid at 70.

${ }^{434}$ Alfred (2005), supra note 40 at 40-41.

${ }^{435}$ Ibid at 46-47.
} 
to frame our thoughts, the ethical framework of our philosophies to make the decision to use our laws and institutions to govern ourselves. ${ }^{436}$

At the same time, RO Porter asserts that there is also an imperative to protect and defend Indigenous sovereignty as the loss of sovereignty can lead to the extinction of distinct Indigenous peoples. ${ }^{437}$ Porter cautions that the stakes are high and that how Indigenous groups strategically engage sovereignty requires careful consideration to overcome to challenges posed by "auto-colonization" and limited resources. ${ }^{438}$ The challenge then is to continue to defend Indigenous sovereignty while simultaneously disengaging from European-derived notions of sovereignty and power.

There are two clear voices in Indigenous scholarships: one that calls for a rejection of sovereignty while the other demands that Indigenous peoples engage the " $\mathrm{S}$ word" 439 as a matter of survival and cultural integrity. Semantics becomes critical to reconciling these two voices. As Corntassel \& Primeau assert, Indigenous discourse regarding sovereignty may actually already captured by the notion of "cultural integrity" as that is already well-defined within international law. ${ }^{440}$ Anaya observes that the international right to "self-determination" is a distinct concept from statehood and a more appropriate objective for Indigenous peoples:

... a U.N. study has concluded ... “... Self-determination, in its many forms, is thus a basic pre-condition if indigenous peoples are to be able to enjoy their fundamental rights and determining their future, while at the same time preserving, developing and passing on their specific ethnic identity to future generations."

$\cdots$

In my view, self-determination should not be equated with a right to independent statehood. Under a human rights approach, the concept of self-

\footnotetext{
${ }^{436}$ Alfred \& Corntassel, supra note 10 at 614.

${ }^{437}$ RO Porter, supra note 10 at 503.

${ }^{438}$ Ibid.

${ }^{439}$ Harold Cardinal, quoted by McCue, supra note 271 at 20 n5.

${ }^{440}$ Corntassel \& Primeau, supra note 10 at 71.
} 
determination is capable of embracing much more nuanced interpretations and applications, particularly in an increasingly interdependent world in which the formal attributes of statehood mean less and less. Selfdetermination may be understood as a right of cultural groupings to the political institutions necessary to allow them to exist and develop according to their distinctive characteristics. ${ }^{441}$

Corntassel \& Primeau cite Anaya for the proposition that Indigenous peoples can strategically achieve cultural integrity by invoking the existing international human rights treaties. $^{442}$ However, Corntassel \& Primeau also contend that "calls for selfdetermination, for an absolute right to self-identification, and for sovereignty only exacerbate tensions between indigenous groups and states." ${ }^{443}$ In this context, it would appear that Anaya and Corntassel \& Primeau have diverging understandings of selfdetermination but all agree upon adopting a human rights approach to ensuring cultural integrity. It becomes increasingly necessary to define these terms clearly to ensure a unified and consistent approach.

A human rights approach to ensuring cultural integrity is more palatable than sovereignty claims for several reasons: (i) it allows Indigenous peoples to disengage from colonial values associated with sovereignty, which undermine Indigenous epistemologies and identity; (ii) it will be more successful than asserting sovereignty through a treatybased approach which must contend with the constraints enumerated by Anaya, namely, intertemporality of international law, the lack of recognition and international tendencies

\footnotetext{
${ }^{441}$ Anaya (1990), supra note 380 at 684-685.

${ }^{442}$ Corntassel \& Primeau, supra note 10 at 68-69.

${ }^{443}$ Ibid at 55 [emphasis added].
} 
towards stability; ${ }^{444}$ and (ii) it allows for a radically inclusive strategy "which is accessible to all indigenous populations",445

It is difficult to imagine a rational justification for a Western tradition of sovereignty in a truly post-colonial world. The global community has repeatedly affirmed its commitment to the elimination of colonialism in all its forms. ${ }^{446}$ However, all indications are that the doctrine of sovereignty is still deeply entrenched in international law. ${ }^{447}$ Alfred suggests that the challenge "in building appropriate postcolonial governing systems is to disconnect the notion of sovereignty from its Western legal roots and transform it."448

\subsection{Conclusion}

In this chapter, I have undertaken a literature review of Indigenous peoples' experiences and perspectives of sovereignty in order to identify some of the alternate narratives and strategies that exist regarding sovereignty. At its core, sovereignty has evolved within the Western legal tradition as an instrument of power over Indigenous peoples, territories and resources. Indigenous peoples have found themselves defined by this narrow and often-violent conception of power, which, at its heart, is contrary to Indigenous peoples' values and epistemologies. This has made it difficult for Indigenous peoples to engage or assert Western sovereignty without also experiencing a form of epistemological assimilation. By engaging with the full spectrum of Indigenous

\footnotetext{
${ }^{444}$ Anaya (1990), supra note 380 at 682-683. Also see Corntassel \& Primeau, supra note 10 at 68-69.

${ }^{445}$ Corntassel \& Primeau, ibid and at 54 where the authors state: "A more universal approach, and one which is accessible to all indigenous populations, is found in existing human rights laws to which most states of the international community are currently party."

${ }^{446}$ Nuxalk Nation, supra note 364 at 689. See also Robert B. Porter, "A Proposal to the Hanodaganyas to Decolonize Federal Indian Control Law" (1998) 31 University of Mich J of L Ref. 899, reprinted in RO Porter, supra note 10, 731 at 731-732.

447 Thorson, supra note 7 at 513.

${ }^{448}$ Alfred (2005), supra note 40 at 42.
} 
discourse regarding sovereignty, a process of cultural and epistemological reclamation can also occur. An articulated vision of Indigenous sovereignty can ultimately allow for the possibility of genuine social and legal reconciliation.

Applying Critical Race Theory, the alternate narratives provided by Indigenous leaders, activists and scholars challenge "the myths of neutrality and objectivity" that surround the doctrine of sovereignty in international law. ${ }^{449}$ It also demonstrates how its use within international water law invokes conflict and confrontation between states and Indigenous peoples on several levels: politically, culturally and philosophically. The conflict found in sovereignty discourse is ultimately a conflict of values about power and how to live and relate to others. A review of Indigenous scholarship reveals key values within Indigenous epistemology, such as the "partnership principle", ${ }^{450}$ the interconnectedness of all living things, the importance of mutual respect and the value of cultivating "inner space" $" 51$ to achieve harmony and balance.

While themes emerge regarding core Indigenous values that provide insights regarding Indigenous sovereignty, the literature review also reveals a plurality of Indigenous perspectives regarding strategies for engaging Western legal sovereignty. Arguably, this observation is in itself part of the process of decolonizing the debate by shattering assumptions that Indigenous peoples share a universal or homogenous relationship with sovereignty. There is considerable debate about how Indigenous peoples should go about emancipating themselves from the oppressive effects of Western legal sovereignty. While some Indigenous scholars prefer to engage inherent sovereignty as a culturally derived phenomenon rooted in language, cultural identity and spirituality,

\footnotetext{
449 Aylward, supra note 27 at 35.

${ }^{450}$ Alfred (2005), supra note 40 at 45.

${ }^{451}$ Ermine (1995), supra note 354 at 103.
} 
others strategize on how to achieve sovereign status within a transformed Western legal paradigm. Some Indigenous leaders emphasize the importance of reclaiming sovereignty by redefining it at an intellectual level. Others focus on the pragmatic political and legal challenges of reconciling state sovereignty with Indigenous sovereignty. Some activists insist that engaging sovereignty discourse is essential to Indigenous peoples' survival while others insist that emancipation is best achieved by disengaging entirely from imperialist values and the related sovereign discourse. There is no clear consensus or strategy within Indigenous scholarship and there continues to be disagreement regarding the differences between key definitions such as sovereignty, cultural integrity and selfdetermination. This is not surprising given that the discourse on Indigenous sovereignty, while rich and diverse, is still an emerging and evolving field of inquiry. ${ }^{452}$

At their root, all of these approaches and perspectives are aimed at reclaiming Indigenous sovereignty and redefining Indigenous-settler relations. It is not within the scope of this paper to resolve or comment upon any of these competing and complex theories or strategies. Rather the purpose of this chapter has been to allow the current narratives regarding Indigenous sovereignty to provide an emerging counterpoint to the dominant legal discourse in order to demonstrate that sovereignty is ultimately a manmade construct. Once we acknowledge sovereignty as a "social creation" [Alfred], we can undertake to (re)construct new laws in a manner that no longer legitimizes the domination of imperialist values over Indigenous values.

In this thesis, I have set out to examine the intersecting relationship between international water law, the doctrine of sovereignty and Indigenous peoples. By understanding Indigenous perspectives regarding the doctrine of sovereignty, it becomes

\footnotetext{
${ }^{452}$ McCue, supra note 271.
} 
apparent how the invocation of sovereign status in the UN Watercourse Convention, to the exclusion of Indigenous nations, only serves to perpetuate the domination of states over Indigenous peoples. It also serves to reinforce and legitimize imperialist values and encourage states' domination and exploitation of territories and resources at the expense of others. In the next chapter, I contend that legal reform of the UN Watercourse Convention is required to create an international law of transboundary rivers that allows for the inclusion of Indigenous values. I maintain that it is possible to envision an international water law that disengages from the politics of sovereignty - at least on a 'without prejudice' basis - such that Indigenous peoples can engage in international water law discourse as full participants without any state or peoples being required to sacrifice their perspectives on sovereignty. 


\section{Chapter 4: Transcending Sovereignty: Reconstructing the International Law of Transboundary Rivers}

The law is not a still pool merely to be tended and occasionally skimmed of accumulated debris, rather it should be looked upon as a running stream, carrying society's hopes, and reflecting all its values, and hence requiring constant attention to its tributaries, the social and other sciences, to see that they feed in sustaining elements. ${ }^{453}$

Former Chief Justice Bora Laskin, Supreme Court of Canada

It is no longer possible to maintain the legitimacy of the premise that there is only one right way to see and do things. ${ }^{454}$

Taiaiake Alfred, Mohawk

A deconstruction of the historical doctrine of sovereignty and the $U N$

Watercourse Convention from a critical Indigenous perspective reveals how sovereignty has evolved within Western legal thought to exclude Indigenous peoples and dominate the environment and its resources. Indigenous perspectives regarding sovereignty weave an alternate narrative that challenges the myth of objectivity, neutrality and power that currently surround the doctrine of sovereignty and international law generally. State interests tend to focus upon the extraction and optimal utilization of natural resources. Western notions of sovereignty have been historically aligned with conquest, domination and exploitation of the natural environment. Given the growing scarcity of fresh water and its importance to all peoples, it is no longer reasonable to assume that states are willing or capable of managing such a precious resource over the long term for current and future generations. Indeed, many scholars have suggested that the complexity of the issues confronting shared water security requires a radically inclusive approach to water

\footnotetext{
${ }^{453}$ Former Chief Justice Bora Laskin of the Supreme Court of Canada, quoted by JW Wilson, People in the Way: The Human Aspects of the Columbia River Project (Toronto: University of Toronto Press, 1973) at 159.

${ }^{454}$ Alfred 2005, supra note 40 at 47.
} 
law and governance. ${ }^{455}$ Blanket acceptance of the supremacy of state sovereignty and state values over the experience and knowledge of Indigenous peoples no longer carries moral legitimacy.

The application of Critical Race Theory to transboundary water laws involves a deconstruction of the legal principles involved and an account of how these laws have systemically excluded Indigenous peoples. It also requires a reconstruction of the law in a manner that remedies that injustice. The question then is how to strategize towards the reform of international water law in such a way that it is inclusive of Indigenous peoples and their traditional laws regarding water governance. The first challenge is to overcome the assumption that international law is not flexible enough to recognize the pre-existing rights of Indigenous peoples.

The UN Watercourse Convention is concerned only with state interests and governs the agreements between sovereigns. On the surface, this appears reasonable given that international law was founded upon the premise that it is comprised of the rules that govern state relations. ${ }^{456}$ However, international law has evolved to recognize the international rights of non-state actors. ${ }^{457}$ Since World War II, there has been growing acceptance among states that the doctrine of sovereignty is not paramount where issues of human rights are concerned. ${ }^{458}$ International human rights law has evolved rapidly in recent decades to place checks upon unfettered state interests and to challenge

\footnotetext{
${ }^{455}$ Karkkainen, supra note 249; Global Water Partnership (2009), supra note 134.

${ }^{456}$ Kate Parlett, The Individual in the International Legal System: Continuity and Change in International Law (New York: Cambridge University Press, 2011) at 3 [Parlett].

${ }^{457}$ Ibid. However, see page 353 where Parlett states "it must be emphasised that states have remained central and in control of the extent to which individuals may engage in the international legal system; the extent to which individuals are given rights, obligations and capacities is dependent upon a specific grant from the primary actors in the international legal system, dominated by states."

${ }^{458}$ Ibid at 338.
} 
the limits of absolute territorial sovereignty. ${ }^{459}$ Likewise, the rights of Indigenous peoples in international law has been evolving over the last century to ensure the protection of the worlds' most vulnerable and marginalized populations against exploitation by the state. Notably, international laws protecting human rights and Indigenous peoples are supported by the majority of sovereigns and reflect the evolving and emerging values of the global community. I contend that the international law of transboundary rivers requires critical scrutiny and reconciliation with the affirmed rights of Indigenous peoples in international law.

In this chapter, I consider the benefits and constraints of pursuing legal reform using a "human rights approach" 460 to assert Indigenous peoples' rights in international water law. I will then provide a brief overview of international instruments that affirm Indigenous peoples' rights and specifically their right to participate in decision-making regarding water. I will then consider several potential avenues for the legal reconstruction of international water law. Ultimately, the process of reconstruction must include the meaningful participation and consensus of Indigenous peoples. This chapter concludes with a call for further analysis and development of strategic approaches to reconstructing international water law in such a way that is inclusive of existing international Indigenous rights.

\subsection{Asserting International Indigenous Rights: Methodology for Reform}

How does one transcend the historical doctrine of sovereignty in international water law and thereby recognize the rights Indigenous peoples' who have traditionally been excluded from the evolution of international water law? Arguably, the key to

\footnotetext{
${ }^{459}$ Ibid.

${ }^{460}$ Anaya (2004), supra note 10 at 7-8.
} 
shifting the discourse away from the doctrine of sovereignty in international water law lies within international Indigenous legal theory and methodology. Indigenous scholars have historically struggled with the entrenchment of the doctrine of sovereignty in international law and yet have succeeded in persuading the vast majority of sovereign states to support, at least in theory, their claims for Indigenous peoples' rights within international law. Over the last 90 years, numerous international instruments have integrated Indigenous values and affirmed Indigenous peoples' rights to selfdetermination, cultural integrity and the right to participate in environmental decisionmaking. ${ }^{461}$ A review of international law of Indigenous peoples and international human rights law demonstrates that the international legal system is flexible enough to recognize the rights of non-state actors and provides a methodology for the legal reform of the international water law.

Anaya is cautiously optimistic in his analysis of Indigenous peoples' success in international law:

Although the words, "all peoples have the right to self-determination" have made their way into the texts of major multilateral treaties, international law has yet to clearly embrace claims for political autonomy beyond the context of classical colonialism. Still the affirmation of self-determination of peoples has provided a wedge for ethnic autonomy claims to make their way prominently into contemporary international legal and political discourse. ${ }^{462}$

Anaya identifies two approaches to Indigenous claims for autonomy in international law: the historical sovereignty approach and the human rights approach. Under the historical sovereignty approach, Indigenous peoples assert self-determination in an effort to reclaim "sovereignty" as it is understood within the Western legal paradigm (ie "a world

\footnotetext{
${ }^{461}$ Patrick Macklem, "Indigenous Recognition in International Law: Theoretical Observations" (20082009) 30 Mich J of Int'l L 177 [Macklem].

${ }^{462}$ Anaya (1990), supra note 380 at 681.
} 
divided into territorially defined, independent or 'sovereign' states"). ${ }^{463}$ Anaya rejects this approach outright as imposing insurmountable "tensions upon the institutional framework of international law." ${ }^{464}$ As previously discussed in Chapter 3 above, Anaya observes several practical constraints of such an approach, namely the doctrine of intertemporal law, the principle of recognition, and the tendency towards stability through pragmatism. ${ }^{465}$

The second approach is the human rights approach, which will be the subject of this chapter. Under this approach, "self-determination is not linked fundamentally to historically derived 'sovereign' entities". ${ }^{466}$ Instead, Indigenous peoples' right to selfdetermination arises from international human rights law and is "derived from notions of freedom, equality, and peace. ${ }^{467}$ Anaya contends that ethnic autonomy is more likely to be achieved on human rights grounds and concludes that claims for independent statehood should be avoided. ${ }^{468}$ He observes that:

... international law has not much upheld sovereignty principles when they serve as an accomplice to the subjugation of human rights or act as a shield against international concern that coalesces to promote human values. ${ }^{469}$

On this analysis, it will be more effective to approach the legal reform of international water law by identifying and reflecting upon the human values upon which transboundary water law is founded. States' interests will inevitably be constrained to the extent that they are contrary or inconsistent with the preservation of human life.

\footnotetext{
463 Ibid at 684.

${ }^{464}$ Ibid at 686.

${ }^{465}$ See page 114-115 above for a discussion of the three limitations of a historical sovereignty approach.

466 Anaya (2004), supra note 10 at 7-8.

467 Anaya (1990), supra note 380 at 684.

468 Ibid at 686.

${ }^{469}$ Ibid at 685-686.
} 
Corntassel \& Primeau also advocate a departure from engaging traditionally Western ideas regarding sovereignty and instead promote the development of strategies based on human rights law. ${ }^{470}$ They argue that, "calls for self-determination, for an absolute right to self-identification, and for sovereignty only exacerbate tensions between indigenous groups and states." ${ }^{471}$ Instead they call for strategies that do "not threaten the territorial integrity or political sovereignty of a majority of states in the international system. ${ }^{, 472}$ The authors contend that international human rights law has already been sufficiently developed to protect the autonomy of Indigenous peoples. ${ }^{473}$ Basic reforms are required to recognize these rights.

In a joint statement to the UN Expert Mechanism on the Rights of Indigenous Peoples regarding a study on Indigenous peoples' right to participate in decision-making, Indigenous representatives made the following recommendation:

Human rights-based approach. It is essential to incorporate a human rights based approach in such forums and processes, consistent with international human rights law. In this context, many processes addressing environment and development issues are in need of basic reforms. ${ }^{474}$

While sufficient rights may already exist within human rights law to protect Indigenous peoples' interests, at issue in this paper is how to ensure that international water law is reconciled with the existing body of human rights laws. Is it possible to reconstruct international water law in a manner that recognizes Indigenous peoples' rights?

In The Individual in the International Legal System (2011), Kate Parlett undertakes an expansive historical review of the international legal system, including the

\footnotetext{
${ }^{470}$ Corntassel \& Primeau, supra note 10.

${ }^{471}$ Ibid at 55.

472 Ibid at 53.

${ }^{473} \mathrm{Ibid}$ at 54.

${ }^{474}$ Gabriel, supra note 14.
} 
evolution of international human rights laws, with the objective of dispelling "myths about state-centrism" ${ }^{475}$ and understanding the mechanics of how the international legal system has evolved to recognize the rights of non-state actors. While her research focuses upon individuals rather than Indigenous peoples, her observations regarding the flexibility of the international legal system to affirm the international rights of non-state actors is informative. Specifically, she offers three reflections regarding the potential for "structural transition in the international legal system", ${ }^{476}$ which can provide guidance in developing a methodology for pursuing rights for Indigenous peoples. She comments upon the following themes: (a) the "relative openness and flexibility of the system" (b) the "forces for structural change: solutions above theories"; and (c) "states in the international legal system". ${ }^{477}$ Each of these observations is summarized briefly below.

\section{Relative openness and flexibility of the system ${ }^{478}$}

Upon tracing the history and mechanics of the emergence of individual rights in the international legal system, Parlett concludes, "[s]tructurally the international legal system is now open to any entity on whom rights, obligations and capacities to function and participate are conferred. ${ }^{, 479}$ Parlett provides several historical examples of the recognition of the rights of non-state actors within the international system and observes:

\footnotetext{
${ }^{475}$ Parlett, supra note 456 at Abstract.

476 Ibid at 365.

${ }^{477}$ Ibid at 365-372. Parlett's analysis includes review of human rights law, international investment law, international claims processes, humanitarian law and international criminal law.

${ }^{478}$ Ibid at 365-367.

${ }^{479}$ Ibid at 365. Parlett adopts the language of "conferring rights". However, the use of the word "confer" suggests that Indigenous peoples' rights are contingent upon state recognition and must be granted by states. This is contrary to Indigenous scholarship, which recognizes the inherent or pre-existing rights of Indigenous peoples. I have chosen to refer to the international legal system's ability to "recognize" these rights rather than to "confer rights" as an acknowledgement of the pre-existing rights of Indigenous peoples.
} 
The particular solutions were creative at the time, given that they were not consistent with the traditional conception of international law as the law applicable to inter-state relations. These examples and others demonstrate that the international legal system has been used to serve changing needs without being constrained by the established understanding of the limits of the international legal framework. ${ }^{480}$

Parlett concludes that it is not contrary to international law to pursue international rights for non-state actors.

Forces for structural change: solutions above theories ${ }^{481}$

Parlett's second observation is that change to the international legal system has

not been brought about through reference to theoretical frameworks or historical

injustices. She observes that:

... the international legal system has experienced structural transition as a result of the need to manage and address practical problems rather than resulting from any deliberate attempt to effect a structural transformation. The international legal system does not appear to be developing along a smooth trajectory from a state-centric international law to a more inclusive international legal system. The picture which emerges is rather that states manage practical questions as they arise by adaptation of the international legal system, and as a result of those practical solutions the international legal system may be transformed. $^{482}$

While theorizing is useful for making arguments that the international system should change, Parlett's analysis suggests that change to the international system is more likely to occur by confronting states with the practical issues complicating transboundary water governance and by demanding creative and collaborative solutions to complex problems.

\footnotetext{
${ }^{480} \mathrm{Ibid}$ at 366. For examples of this openness in practice, see Parlett, Part II: The Individual in International Law. Parlett cites the ECHR in 1950 and the two UN Conventions in the 1960s, which articulate the rights of individuals and the corresponding obligations of states. In addition, international humanitarian laws expressed in the Geneva Convention (Art. 3) and Additional Protocol II, recognize the rights and obligations of insurgent groups and individuals within the context of civil conflict.

${ }^{481}$ Ibid at 367-369.

${ }^{482}$ Ibid at 368.
} 
States in the international legal system ${ }^{483}$

Finally, Parlett observes that, despite the emergence of rights for non-state actors, the international legal system continues to remain dominated by sovereign states. From this state-centric perspective, rights are "conferred" onto individuals and other non-state entities by state agreement and there continue to be systemic limits that ensure that the international legal system remains within the control of sovereigns. ${ }^{484}$ The post-1945 international legal system is therefore flexible enough to allow for the creation of rights for non-state actors but it is ultimately constrained by the process of agreement and the granting of such rights by sovereign states. Parlett concludes,

While it is increasingly common for individuals to be given rights and obligations ... the conferral of rights and obligations has been exclusively dependent on the consent of states.... Where rights are conferred by treaty, they are created by the state parties to the treaty. Where rights are created by customary international law, that custom is the consequence of state practice or at least failure of states to persistently object to the formation of a customary rule. And while certain rules in the field of human rights have claim to jus cogens status, they have originated in a rule agreed to or acquiesced in by states. ${ }^{485}$

Parlett further cautions:

The conferral of rights and obligations on individuals might, on one view, be seen as a move away from a state-dominated international legal system. But another view might be that the conferral of rights and obligations on individuals -which is exclusively controlled by states - actually reinforces the dominant position of states in the international legal system, to an extent which might not have been possible without some concessions or participatory rights granted to individuals. ${ }^{486}$

\footnotetext{
${ }^{483}$ Ibid at $369-372$.

${ }^{484}$ Ibid at 350.

${ }^{485} \mathrm{Ibid}$ at 361.

${ }^{486} \mathrm{Ibid}$ at 370.
} 
The ability to affect reform of and access to international water law therefore remains dependent upon state consent within a state-dominated system and to that extent, Indigenous peoples remain subordinated by the doctrine of sovereignty. ${ }^{487}$

In "Indigenous Recognition in International Law: Theoretical Observations", Patrick Macklem reviews the evolution of Indigenous peoples rights in international law over the last 100 years and the relationship between international Indigenous rights and the doctrine of sovereignty. ${ }^{488} \mathrm{He}$ offers his observations regarding "the legal requirements of indigenous recognition in international law, the relation between legal recognition of States and legal recognition of indigenous peoples, and the nature and purpose of international indigenous rights." ${ }^{, 49}$ Macklem observes that, unlike recognition of individuals in international law, recognition of Indigenous peoples and tribal communities has evolved in direct response to their historic exclusion from imperialist definitions of sovereignty that have formed the basis of the international legal order. He notes that:

... the process of sovereign exclusion and inclusion is not a one-shot affair, occurring some time in the distant past when international law accepted the proposition that indigenous territory constituted terra nullius. It is an ongoing process of exclusion and inclusion to the extent that it continues to subsume indigenous populations under the sovereign power of States not of their making. 490

\footnotetext{
${ }^{487}$ Ibid at 361. See Parlett's reference to McCorquodale at 361: “.. he suggests that, to a certain extent, individuals do have an independent role in the international legal system; that they 'do have considerable international rights and responsibilities in the system, a number of which are independent from a State's ability to control or determine them'. In the context of rights, McCorquodale refers to customary international human rights and jus cogens, suggesting that these norms may have developed 'without a State having an express practice on the issue'."

${ }^{488}$ Macklem, supra note 461.

${ }^{489}$ Ibid at 180.

${ }^{490}$ Ibid at 186.
} 
Upon reviewing the evolution of Indigenous rights over the last century, Macklem contends that "[d]etermining the criteria for legal recognition of Indigenous peoples requires taking an interpretive stand on the nature and purpose of international indigenous rights themselves." ${ }^{491}$ One interpretation is that the purpose of international Indigenous rights is to remove the existing barriers that prevent Indigenous peoples from enjoying the same human rights that all people enjoy, including the right to self-determination. Macklem concludes that we should resist the tendency to simply apply a universal human rights approach to Indigenous peoples' rights. He states:

What the legal history of international indigenous protection reveals is that indigenous rights in international law are differentiated rights that recognize differences, partly denied and partly produced by the international distribution of territorial sovereignty initiated by colonization, that exist between indigenous and non-indigenous peoples. International indigenous rights speak to the consequences of organizing international political reality, including indigenous political reality, into a legal system that vests sovereign power in certain collectivities and not others. Not only does this mode of legal organization exclude indigenous peoples from participating in the distribution of sovereign power that it performs, it authorizes legal actors to whom it distributes sovereign power - States - to exercise such power over indigenous peoples and territory to their detriment. The morally suspect foundations of these baseline legal entitlements are why indigenous rights merit recognition on the international legal register. A failure to respect international indigenous rights in the words of Michael Reisman, "re-enacts the tragedy of colonialism". 492

International Indigenous rights are not significant simply because of their appeal to universal human rights but also because Indigenous peoples are defined by an institutional legal system that was predicated upon their exclusion. Indigenous rights evolved to mitigate the adverse consequences of colonialism. Therefore, a failure to implement and recognize those rights perpetuates colonial domination and exploitation of Indigenous peoples. Indigenous rights embody more than just an appeal to the

\footnotetext{
${ }^{491}$ Ibid at 207.

${ }^{492}$ Ibid at 208 [emphasis added].
} 
universality of human rights but also a commitment to "post-imperial values". 493

Macklem describes the purpose of international Indigenous rights as follows:

The twentieth-century legal history of international indigenous rights from their origins in international protection of indigenous workers in colonies to their contemporary expression in the UN Declaration on the Rights of Indigenous Peoples, demonstrates that their purpose is to mitigate injustices produced by the way in which the international legal order conceives of sovereignty as a legal entitlement that it distributes among collectivities that it recognizes as States. The criteria by which indigenous peoples can be said to exist in international law relate to their historic exclusion from the distribution of sovereignty initiated by colonization that lies at the heart of the international legal order. ${ }^{494}$

While Indigenous rights may be characterized as mitigating the adverse impacts of the distribution of sovereignty, they do not challenge the existing international legal system or strengthen Indigenous claims for sovereignty. If anything, the assertion of Indigenous rights requires the on-going recognition of the dominance and authority of states within international law. $^{495}$

Macklem's and Partlett's observations regarding the flexibility and constraints of the international legal system provide support for the argument that the best approach to affect reform is by invoking the current body of human rights and international Indigenous rights. Rather than asserting sovereignty, the rights of non-state actors are more likely to be recognized by appealing to human values and by providing creative solutions to complex issues. Parlett's and Macklem's historical analyses and

\footnotetext{
${ }^{493}$ See Alfred (2005), supra note 40 at 38 where Alfred states that the three post-imperial values include "consent, mutual recognition, and cultural continuity."

${ }^{494}$ Macklem, supra note 461 at 210 [emphasis added].

${ }^{495}$ However, if there are circumstances of colonizaion and oppression by the state, there is still a remedy of self-determination. See Western Sahara, Advisory Opinion, (16 October 1975) ICJ 12, online: ICJ <http://www.icj-cij.org/docket/index.php?p1=3\&p2=4\&k=69\&case=61\&code $=$ sa \&p3=4>.
} 
observations also point to the requirement of Indigenous peoples to acknowledge the continued dominance of states as "the crucial actors" in the international legal system. ${ }^{496}$

The systemic constraints of the state-centred international legal system are not insurmountable. There is ample precedent both within human rights law and the international law of Indigenous peoples that exemplify states' willingness to acknowledge the international rights of Indigenous peoples. Furthermore, international agencies are increasingly committed to the implementation of Indigenous peoples rights across the international legal system. The next section provides a brief overview of these precedents.

\subsection{Recognizing International Indigenous Rights: Precedents for Reform}

Over the last century, the majority of states have repeatedly affirmed Indigenous peoples' rights in international law. Macklem traces the emergence of international legal protection of Indigenous peoples back to the 1884 Berlin Conference on Africa at which imperial powers divided up Africa in an effort to reduce the tensions of competing claims of sovereignty. ${ }^{497}$ While simultaneously excluding Indigenous peoples from exercising sovereignty, there was also a parallel recognition that the sovereigns had a legal duty to protect the colonies under their control. In 1919, this duty to protect Indigenous peoples was codified in the Covenant of the League of Nations as sovereigns undertook "to secure just treatment of the native inhabitants of territories under their control". ${ }^{498}$ The International Labour Organization undertook to establish guidelines regarding the

\footnotetext{
${ }^{496}$ Macklem, supra note 461 at 209; Parlett, supra note 456 at 325.

${ }^{497}$ Macklem, ibid at 187.

${ }^{498}$ Covenant of the League of Nations: Article 23, Creation of Mandates, (28 June 1919) para b, on-line: African History <http://africanhistory.about.com/od/eracolonialism/qt/MandateA23.htm>, cited in Macklem, ibid.
} 
working conditions of Indigenous peoples as early as $1921 .^{499}$ More recently, the United Nations recognized "discrimination against indigenous populations" when the U.N. SubCommission on the Prevention of Discrimination and Protection of Minorities commissioned a study through Resolution 1589, to report upon the situation of Indigenous peoples globally. ${ }^{500}$ The study which resulted from Resolution 1589, the Martínez Cobo Report (1983), made several proposals and recommendations regarding the future of international Indigenous rights. ${ }^{501}$ Macklem identifies three recommendations of the report that are of particular significance:

First, it proposed distinguishing between indigenous and non-indigenous communities on the basis of historical continuity with pre-invasion and precolonial times. ...

Second ... [i]t noted "the widespread and open rejection by indigenous peoples of the concept of integration," and argued that "[s]elf-determination, in its many forms, must be recognized as the basic precondition for the enjoyment by indigenous peoples of their fundamental rights and the determination of their own future."

Third, it recommended the adoption of the U.N. Declaration on indigenous rights as an interim step to the adoption of an international convention on the topic. $^{502}$

As a result of the Report's recommendations, the Sub-Commission established the Working Group on Indigenous Populations, which began work on a draft declaration on the rights of Indigenous Peoples in 1985. Approximately 22 years later, UNDRIP was ratified by the UN General Assembly in 2007. It is relevant to provide these historical milestones to help situate the ratification of UNDRIP and the other international

\footnotetext{
${ }^{499}$ Ellen Lutz, "The Right to Water" in (Sept/Oct 2006) 40:5 Canadian Dimension 43 [Lutz]. Also see Macklem, ibid at 188 regarding the International Labour Organization's establishment of a Committee of Experts on Native Labour in 1926.

${ }^{500}$ UN Econ \& Soc Council, Res 1589(L), para 7, 50 ${ }^{\text {th }}$ Sess., Supp No 1, UN Doc E/5044 (21 May 1971) [Resolution 1589]; Macklem, supra note 461 at 198.

${ }^{501}$ UN Permanent Forum on Indigenous Issues [UNPFII], Study of the Problem of Discrimination Against Indigenous Populations, (consolidated) UN DOC ECN4Sub.219867 and Add1-4 (28 June 1983) (prepared by José Martínez Cobo), online: United Nations <http://www.un.org/esa/socdev/unpfii/en/spdaip.html> [Martínez Cobo Report].

${ }^{502}$ Macklem, supra note 461 at 199-200 [emphasis added].
} 
instruments discussed below within the century-long evolution of Indigenous rights and also as part of the longer term vision of an international convention on Indigenous peoples' rights.

While a thorough historical review of all international instruments that acknowledge Indigenous peoples' rights is beyond the scope of this paper, I will briefly review several of the more prominent instruments below with particular attention paid to Indigenous peoples' rights regarding water. ${ }^{503}$ Specifically, this section will consider Indigenous peoples' right to water within the context of International Labour Organisation Convention No 169 on Indigenous and Tribal Peoples of 1989 [ILO No $169]^{504}$, UNDRIP, customary international law and norms, and the UN Declaration on the Human Right to Water. ${ }^{505}$

\subsubsection{ILO No 169}

ILO No 169 is a legally binding international instrument, which specifically addresses the rights of Indigenous and tribal peoples. As of January 2012, 22 countries had ratified it. ${ }^{506}$ While $I L O$ No 169 does not expressly reference water, it contains several provisions that recognize Indigenous peoples' right to cultural integrity as well as land and resource rights. ${ }^{507}$

Article 7 states:

\footnotetext{
${ }^{503}$ For further analysis of international Indigenous rights prior to 2005, see David H Getches, "Indigenous Peoples' Rights to Water Under International Norms” (2005) 16 Colo J Int'l Envtl L \& Pol'y 259 [Getches]; Macklem, supra note 461; and Lutz, supra note 499.

${ }^{504}$ International Labour Organisation Convention No 169 Concerning Indigenous and Tribal Peoples in Independent Countries, 27 June 1989, 1650 UNTS 383 (entered into force Sept. 5, 1991) [ILO No 169].

${ }^{505}$ General Assembly Adopts Resolution Recognizing Access to Clean Water, Sanitation as Human Right, by Recorded Vote of 122 in Favour, None against, 41 Abstentions, GA Res GA/10967, UN GAOR, 64 ${ }^{\text {th }}$ Sess, $108^{\text {th }}$ Mtg (28 July 2010), online: <http://www.un.org/News/Press/docs/2010/ga10967.doc.htm> [UN GA Res GA/10967].

506 International Labour Organization, "Convention No C169", online: ILO <http://www.ilo.org/ilolex/cgilex/ratifce.pl?C169>.

${ }^{507}$ Getches, supra note 503 at 263.
} 
1. The peoples concerned shall have the right to decide their own priorities for the process of development as it affects their lives, beliefs, institutions and spiritual well-being and the lands they occupy or otherwise use, and to exercise control, to the extent possible, over their own economic, social and cultural development. In addition, they shall participate in the formulation, implementation and evaluation of plans and programmes for national and regional development which may affect them directly.

4. Governments shall take measures, in co-operation with the peoples concerned, to protect and preserve the environment of the territories they inhabit.

Article 15 reads:

1. The rights of the peoples concerned to the natural resources pertaining to their lands shall be specifically safeguarded. These rights include the right of these peoples to participate in the use, management and conservation of these resources.

Article 32 is particularly relevant within the context of transboundary water governance:

Governments shall take appropriate measures, including by means of international agreements, to facilitate contacts and co-operation between indigenous and tribal peoples across borders, including activities in the economic, social, cultural, spiritual and environmental fields.

Underlying all of the provisions of ILO No 169 is an emphasis on consultation with and participation by Indigenous peoples in an effort to "stimulate dialogue between governments and indigenous and tribal peoples". ${ }^{508}$ While the Convention has only been ratified by 22 countries, the adoption of $U N D R I P$ is perceived as exemplifying the broader acceptance of the principles underlying ILO No $169 .{ }^{509}$ Getches observes that there is an argument for the extension of ILO No 169 to all states as it reflects emerging “customary international law's recognition of indigenous peoples' property rights in natural resources that they have traditionally used". 510

\footnotetext{
${ }^{508}$ International Labour Organization, “Convention No 169", online: ILO <http://www.ilo.org/indigenous/Conventions/no169/lang--en/index.htm>. ${ }^{509} \mathrm{Ibid}$.

${ }^{510}$ Getches, supra note 503 at 274.
} 


\subsubsection{UNDRIP}

UNDRIP was initially adopted on September 13, 2007 with 144 countries in favour, 4 countries voting against and 11 countries abstaining. ${ }^{511}$ While numerous provisions of the Declaration affirm an indirect right to water incidental to Indigenous peoples' rights to cultural integrity and economic development, Articles 25 and 32(2) expressly affirm Indigenous Peoples' rights to water. ${ }^{512}$

Article 25 Indigenous peoples have the right to maintain and strengthen their distinctive spiritual relationship with their traditionally owned or otherwise occupied and used lands, territories, waters and coastal seas and other resources and to uphold their responsibilities to future generations in this regard.

Article 32 (2) States shall consult and cooperate in good faith with the indigenous peoples concerned through their own representative institutions in order to obtain their free and informed consent prior to the approval of any project affecting their lands or territories and other resources, particularly in connection with the development, utilization or exploitation of mineral, water or other resources. ${ }^{513}$

In addition, Articles 26 and 29 specifically invoke States' obligations regarding "protection of these lands, territories and resources" (art. 26) and "protection of the environment and the productive capacity of their lands or territories or resources" (art. 29). Article 38 provides that "States in consultation and cooperation with indigenous peoples, shall take the appropriate measures, including legislative measures, to achieve the ends of this Declaration."

As a General Assembly resolution, adoption of UNDRIP does not generally

${ }^{511}$ UNDRIP, supra note 13; United Nations Bibliographic Information System, supra note 23.

${ }^{512}$ UNDRIP, ibid.

${ }^{513}$ Ibid at Art 25 \& 32(2). 
impose legally binding obligations upon states. ${ }^{514}$ However, through the process of implementation of $U N D R I P$, international agencies and states are strengthening the argument that the general principles set out in UNDRIP represent customary international law. In addition, the Inter-American Court of Human Rights has relied upon UNDRIP as persuasive evidence of state legal obligations to Indigenous peoples. ${ }^{515}$ Arguably, an argument for Indigenous peoples' right to water can be made with reference to UNDRIP and many other international conventions.

\subsubsection{Customary International Law}

In addition to these major instruments, Getches contends that Indigenous peoples' rights may be derived from international customs found in both human rights laws and environmental laws. Getches observes:

Based largely on the content of international human rights conventions and customs apart from domestic laws, John Alan Cohan argues that "the international community now regards indigenous peoples as having environmental rights that rise to the status of international norms" and that "because indigenous peoples' way of life and very existence depends on their relationship with the land, their human rights are inextricable from environmental rights". 516

Getches contends that customary international law can be invoked to support Indigenous peoples' rights to water on several grounds, including (i) protection for Indigenous lands and resources; (iii) environmental protection; (iii) subsistence rights; (iv) cultural identity; (v) freedom from racial discrimination; and (vi) right to self-determination. ${ }^{517}$

\footnotetext{
${ }^{514}$ Lutz, supra note 499. However, see Parmar, infra note 527 at 35-37. The right to water is emerging from other rights already affirmed in the ICESCR and the Universal Declaration of Human Rights [UDHR], and in particular the right to an adequate standard of living. While, resolutions of the General Assembly are not binding, the provisions of the UDHR are generally accepted as customary international law.

${ }^{515}$ Case of the Saramaka People v Suriname (28 November 2007), IACHR (ser C) No 172 [Saramaka People].

${ }^{516}$ Getches, supra note 503 at 264.

${ }^{517}$ Ibid at 271-292.
} 
For example, Getches points to Agenda 21 adopted at the 1992 United Nations

Conference on Environment and Development in Rio de Janeiro as one example of international adoption of environmental standards that expressly includes the full engagement and participation of Indigenous peoples. ${ }^{518}$

The United Nations International Covenant on Economic, Social and Cultural Rights (ICESCR $)^{519}$ does not expressly refer to the right to water but it is reasonably inferred from affirmed cultural, economic and social rights. Article 1 states:

1. All peoples have the right of self-determination. By virtue of that right they freely determine their political status and freely pursue their economic, social and cultural development.

2. All peoples may, for their own ends, freely dispose of their natural wealth and resources without prejudice to any obligations arising out of international economic co-operation, based upon the principle of mutual benefit, and international law. In no case may a people be deprived of its own means of subsistence.

3. The States Parties to the present Covenant, including those having responsibility for the administration of Non-Self-Governing and Trust Territories, shall promote the realization of the right of self-determination, and shall respect that right, in conformity with the provisions of the Charter of the United Nations.

Article 11 articulates "the right to share in efficient agrarian systems", while Article 12 includes "a right to a secure, healthy, and ecologically sound environment." ${ }^{, 520}$ Arguably, all of these rights are contingent upon healthy water sources.

Principle 20 of the Vienna Declaration adopted by the 1993 United Nations World Conference on Human Rights specifically calls for the protection of the cultural integrity of Indigenous peoples. Given the interconnectedness between Indigenous peoples'

\footnotetext{
${ }^{518}$ Ibid at 263; Agenda 21, Report of the UNCED, I, UN CED, (1992), DocA/CONF. 15126 (Vol. II) online: United Nations <http://www.un.org/esa/sustdev/documents/agenda21/english/agenda21toc.htm> [Agenda 21].

${ }_{519}$ International Covenant on Economic, Social, and Cultural Rights, 19 Dec 1966, 993 UNTS 3 [ICESCR].

${ }^{520}$ Getches, supra note 503 at 282.
} 
cultural and spiritual identities and their surrounding environment, states' obligations to protect Indigenous peoples' cultural integrity would include a prohibition against the depletion or contamination of Indigenous water sources. ${ }^{521}$

Getches also points to the rules and policies of international development agencies such as the World Bank and the Inter-American Bank, to further argue that Indigenous rights have become accepted as international norms. ${ }^{522}$ Institutional support for the principles of UNDRIP exists throughout the UN system of government. The InterAgency Support Group on Indigenous Peoples (IASG) was established to support the recommendations of the United Nations Permanent Forum on Indigenous Issues. ${ }^{523}$ IASG's 31 members include the I.L.O, the World Bank, the European Union, the World Health Organization, UNICEF, the World Intellectual Property Office (WIPO), the United Nations Development Program (UNDP), the International Fund for Agricultural Development (IFAD) and the Secretariat of the Convention on Biological Diversity (SCBD) ${ }^{524}$ Its mandate has been expanded to support the implementation of Indigenous rights throughout the international system. In 2007, the IASG adopted the following statement regarding UNDRIP:

The Inter Agency Support Group on Indigenous Peoples' Issues hails the adoption of the Declaration on the Rights on Indigenous Peoples by the General Assembly on 13 September 2007. The Declaration sends out a clear message to the entire international community, reaffirming the human rights of the world's indigenous peoples. This landmark action of the United Nations bears political, legal, symbolic and moral significance, as well as

\footnotetext{
${ }^{521}$ Ibid at 283 .

${ }^{522}$ Ibid at 265-267. Getches cites in particular, World Bank Operational Procedure 4.10, 4.20; InterAmerican-Development Bank Operational Policy 2.4

${ }^{523}$ Connie Tarcena, "Implementing the Declaration: A State Representative Perspective" in Jackie Hartley, Paul Joffe, \& Jennifer Preston, eds, Realizing the UN Declaration on the Rights of Indigenous Peoples:

Triumph, Hope, and Action, (Saskatoon: Purich Publishing Ltd, 2010) 60. See also UN Permanent Forum on Indigenous Issues [UNPFII], "IASG / Inter-Agency Support Group on Indigenous Issues", online: UN $<$ http://www.un.org/esa/socdev/unpfii/en/iasg.html>.

${ }^{524}$ UNPFII, ibid.
} 
constituting a crucial opportunity for the UN System and other intergovernmental organizations to critically reflect upon their engagement with indigenous peoples' issues and, according to Article 42 of the Declaration, to promote respect for and full application of its provisions and follow-up its effectiveness. The IASG pledges to advance the spirit and letter of the Declaration within our agencies' mandates and to ensure that the Declaration becomes a living document throughout our work. ${ }^{525}$

The vast majority of sovereigns and international agencies have indicated their commitment to the principles of UNDRIP and to their support of Indigenous peoples' rights generally.

While there are only a few express references to water in these international instruments, an Indigenous right to water can be reasonably inferred from several other rights that are contingent upon water. The United Nation's recent affirmation of the human right to water provides further support for a reconstruction of international water law with reference to Indigenous peoples' rights. ${ }^{526}$

\subsubsection{The Human Right to Water}

The UN General Assembly's affirmation of a human right to water provides further legitimacy to a proposal for reconstructing transboundary water law with reference to human rights and in a manner that is inclusive of Indigenous peoples. ${ }^{527}$ On

\footnotetext{
${ }^{525}$ UNPFII, “Inter-Agency Support Group”, online: UN $<$ http://social.un.org/index/IndigenousPeoples/InterAgencySupportGroup.aspx>.

${ }^{526}$ For a general review of UN declarations regarding water, see generally UN University, Deep Words, Shallow Words: An Initial Analysis of Water Discourse in Four Decades of UN Declarations, report from the UNU Institute for Water and Health, (October 2011), online: United Nations University <http://www.inweh.unu.edu/River/documents/DeepWords_ShallowWords\%20_Mount\&Bielak_FINAL_pd f_Oct_26_2011.pdf>.

${ }^{527}$ However, even then the mainstream discourse on the human right to water requires critical analysis from Indigenous peoples' perspectives. See Pooja Parmar, Revisiting the Human Right to Water (LLM Thesis: University of British Columbia, Faculty of Law, 2006) [unpublished], for a discussion and analysis regarding the inadequacy of the mainstream discourse on the human right to water to address the realities of small communities in rural India. Parmar concludes that, "[c]ontemporary attempts to formulate the human right to water tend to focus almost exclusively on the right as an entitlement to water supply while ignoring the implications of such a right as a freedom. The 'human' is reduced to a consumer, a 'right' to only a need, and water as nothing more than a commodity that is to be 'managed' and 'supplied' by the
} 
July 28, 2010, the United Nations passed a general resolution, which declared that water is a human right; with 122 countries voting in its favour while 41 countries abstained. ${ }^{528}$ Specifically, the resolution: "[d]eclares the right to safe and clean drinking water and sanitation as a human right that is essential for the full enjoyment of life and all human rights." On October 1, 2010, the United Nations Human Rights Council ("HRC”) confirmed that the human right to water is legally binding and "justiciable". ${ }^{529}$ The HRC confirmed that the right to water and sanitation is inextricably linked to the right to an adequate standard of living, which is already codified in many international human rights treaties, including the ICESCR. ${ }^{530}$ In doing so, the HRC clarified "the foundation for recognition of the right and the legal standards which apply.",531

While some states have argued that the right to water is still ambiguous for the purposes of state implementation, ${ }^{532}$ General Comment No. 15 to the ICESCR (Nov. 2002) provides substantive guidelines outlining state obligations and the steps to

state, the market, or a combination of the two with 'participation' rights to the people." She concludes that, "[a] right to water as being formulated within the international human right law is inadequate to address the suffering of the people here. In fact with its focus on entitlements, needs, development and governance, such a formulation, even when it goes beyond its current position as 'soft law', will be of little consequence to many people who increasingly find themselves positioned against hegemonic global forces today." (9394).

In "A Human Right to Water: Domestic and International Implications" (1992), McCaffrey concluded that the human rights to an adequate standard of living, health and well-being and to food necessarily require an "adequate supply of water". See generally Steven McCaffrey, "A Human Right to Water: Domestic and International Implications" (1992) 5 Geo. Int'l Env L R 1 at 8.

${ }^{528}$ UN GA Res GA/10967, supra note 505; Canadian Union of Public Employees (CUPE), "UN passes Human Right to Water and Sanitation resolution" CUPE (Jul 29, 2010), online: CUPE $<$ http://cupe.ca/human-rights/un-passes-historic-human-water>.

${ }^{529}$ UN News Centre, "Right to water and sanitation is legally binding, affirms key UN body" (1 October 2010), online: United Nations $<$ http://www.un.org/apps/news/story.asp?NewsID=36308\&Cr=water\&Cr1=>.

${ }^{530}$ ICESCR, supra note 519; United Nations Office of the High Commissioner of Human Rights (OHCHR), "UN united to make the right to water and sanitation legally binding" (1 October 2010), online: OHCHR <http://www.ohchr.org/en/NewsEvents/Pages/DisplayNews.aspx?NewsID=10403\&LangID=E> [OHCHR]. ${ }^{531}$ OHCHR, ibid.

${ }^{532}$ Indraguptha, supra note 67 at 20. 
implementing water rights. ${ }^{533}$ Specifically, General Comment No. 15 sets out the guidelines for state parties regarding the interpretation of the right to water under Article 11 (the right to an adequate standard of living) and Article 12 (the right to health). ${ }^{534}$ As with all human rights, state parties have three obligations under the ICESCR:

i) Respect: "The obligation to respect requires that States parties refrain from interfering directly or indirectly with the enjoyment of the right to water." 535

ii) Protect: "The obligation to protect requires State parties to prevent third parties from interfering in any way with the enjoyment of the right to water. ... The obligation includes, inter alia, adopting the necessary and effective legislative and other measures to restrain, for example, third parties from denying equal access to adequate water; and polluting and inequitably extracting from water resources, including natural sources, wells and other water distribution systems." ${ }^{, 536}$

iii) Fulfil: "The obligation to fulfil can be disaggregated into the obligations to facilitate, promote and provide. The obligation to facilitate requires the State to take positive measures to assist individuals and communities to enjoy the right. The obligation to promote obliges the State party to take steps to ensure that there is appropriate education concerning the hygienic use of water, protection of water sources and methods to minimize water wastage. States parties are also obliged to fulfil (provide) the right when individuals or a group are unable, for reasons beyond their control, to realize that right themselves by the means at their disposal. ${ }^{, 537}$

In addition, Article 16 of General Comment 15 provides specific guidance to states regarding their obligations to Indigenous peoples: “... State parties should take steps to ensure that: ... (d) Indigenous peoples' access to water resources on their ancestral lands

\footnotetext{
${ }^{533} \mathrm{UN}$ ESCOR, General Comment No. 15: The right to water (arts. 11 and 12 of the International Covenant on Economic, Social and Cultural Rights), $29^{\text {th }}$ Sess, UN Doc. E/C.12/2002/11 (2002) [General Comment No. 15]. Parmar, supra note 527 at 35 observes that General Comment No 15 is non-binding and therefore is 'soft law' that "expands and clarifies the right to water which is derived and inferred from other human rights."

${ }^{534}$ Ibid. Also see Parmar, supra note 527 at 35-37. The right to water is emerging from other rights such as the right to an adequate standard of living already affirmed in the ICESCR, supra note 519, and the Universal Declaration of Human Rights, GA Res 217 (III), UN GAOR, 3d Sess, Supp No 13, UN Doc A/810 (1948) [UDHR]. While, resolutions of the General Assembly are not binding, the provisions of the UDHR are generally accepted as customary international law. In McCaffrey (1992), supra note 527 at 8, McCaffrey concluded that the human rights to an adequate standard of living, health and well-being and to food necessarily require an "adequate supply of water".

${ }_{535}$ General Comment No 15, supra note 533 at Art 21.

${ }^{536}$ Ibid at Art 23.

${ }^{537}$ Ibid at Art 25.
} 
is protected from encroachment and unlawful pollution. States should provide resources

for indigenous peoples to design, deliver and control their access to water." ${ }^{„ 58}$

Most of the scholarship regarding an Indigenous right to water focuses on establishing remedies under international law for violations of international Indigenous rights that can not be remedied at the national level. I contend that the international instruments that recognize Indigenous rights may also be relied upon to support a call for the reform and/or reconstruction of the existing body of international water law in a manner that recognizes Indigenous peoples' rights. While state consensus is required for the creation of new international instruments that recognize the inherent rights of Indigenous peoples, the evidence demonstrates that the vast majority of states and international agencies are ready to recognize Indigenous peoples' rights within the context of transboundary water law.

\subsection{Implications for International Water Law: Proposals for Reconstruction}

Based on the methodology and precedents reviewed above, this chapter promulgates possible strategies for the reconstruction of transboundary water law in a manner that recognizes and implements the rights of Indigenous peoples in international law. While theoretical arguments abound for challenging the moral legitimacy behind the doctrine of sovereignty, the practicalities of the international legal order call for a pragmatic approach to reform that does not directly challenge state sovereignty at this time.

In my view, the reconstruction of international water law requires a legal reconciliation between two co-existing bodies of international law: transboundary water

\footnotetext{
${ }^{538}$ Ibid at Art 16.
} 
law and international Indigenous rights. Such reconciliation necessarily requires the full engagement of Indigenous peoples through internationally recognized agencies such as the UN Permanent Forum on Indigenous Issues and the Expert Mechanism on the Rights of Indigenous Peoples. ${ }^{539}$ I briefly propose some avenues for reform that may warrant further exploration and analysis.

First, the UN Watercourse Convention could be amended to require state recognition of UNDRIP. ${ }^{540}$ For example, a provision could be inserted to protect Indigenous peoples rights as follows:

Watercourse States shall, individually and, where appropriate, in cooperation with other States, take all measures with respect to an international watercourse that are necessary to protect and preserve the rights of Indigenous peoples, taking into account generally accepted international rules and standards, including but not limited to the United Nations Declaration on the Rights of Indigenous Peoples. ${ }^{541}$

The implementation of such a provision would require states to ensure that they obtain the free and prior informed consent of Indigenous peoples in the development of their bilateral or multilateral state development agreements as well as recognition of Indigenous peoples' legal systems and customs. ${ }^{542}$ The limitations of such an approach to reform is obvious. Even if reference to $U N D R I P$ were included in the $U N$ Watercourse Convention, the ability to enforce the provision on behalf of Indigenous peoples would remain solely with states, as the only parties to the Convention. Further, it

\footnotetext{
${ }^{539}$ Getches, supra note 503 at 294 , cautions that "it would be wise for indigenous groups from several countries to coordinate regional or international efforts to find the best cases to advance the development of international law as a tool for securing indigenous water rights."

${ }^{540}$ Arguably, such an amendment would also require a more general requirement of states to protect the human right to water

${ }^{541}$ The language proposed mirrors UN Watercourse Convention, supra note 15 at Art 23, regarding Protection and preservation of the marine environment which states: "Watercourse States shall, individually and, where appropriate, in cooperation with other States, take all measures with respect to an international watercourse that are necessary to protect and preserve the marine environment, including estuaries, taking into account generally accepted international rules and standards."

${ }^{542}$ UNDRIP, supra note 13 at Art 32(2).
} 
is highly unlikely that that the Convention would be ratified with this amendment. Even without amendment, the UN Watercourse Convention has failed to obtain the requisite number of signatories required for ratification. ${ }^{543}$ While a call for reform of the Convention may be justified, it is unlikely to have a practical impact upon Indigenous rights.

A second and potentially more potent recommendation for reform could involve targeting bilateral and multi-lateral agreements themselves. As discussed in Chapter 2 above, the principles of customary international water law are largely obtained by reference to state agreements. Indigenous peoples in some regions such as the Columbia River Basin have obtained sufficient domestic rights and political power to demand recognition of $U N D R I P$ and the human right to water in the imminent re-negotiation of the Columbia River Treaty. While Canada and the United States would likely resist any attempt to make the principles of UNDRIP contractually binding, the cooperation of Indigenous peoples on both sides of the border along with the pressure of international agencies could place such a proposal squarely on the negotiating table. The recognition of UNDRIP and the human right to water in future bilateral and multilateral state agreements would also serve the dual purpose of (i) advancing UNDRIP as customary international law and (ii) advancing the protection of Indigenous rights as a principle of customary international water law. This approach would provide a valuable precedent for Indigenous peoples in other river basins to advocate for state recognition of their rights in transboundary agreements. However, as with a reform of the Convention,

\footnotetext{
${ }^{543}$ Dixon suggests that further analysis is required to determine why the Convention has failed to be ratified. See Rebecca Anne Dixon, "Global Water Sensitivity of Transboundary Rivers - Levels \& Leakages: The Nile and the Implications for Global Water" (2010) 6 Human Security, online: Atlantic International Studies Organization <http://atlismta.org/online-journals/human-security/global-watersensitivity-of-transboundary-rivers/> [Dixon].
} 
recognition of Indigenous rights in transboundary agreements would be limited by the reality that Indigenous peoples would remain dependent upon states to enforce their rights. Notwithstanding this limitation, lobbying for the inclusion of UNDRIP and the human right to water in transboundary river agreements deserves merit for its potential to aid in global efforts to recognize Indigenous peoples' rights.

Arguably, neither of the first two proposals goes far enough to mitigate the adverse impacts of Indigenous peoples' exclusion from the sovereign community or address the complexity of the current challenges regarding transboundary river governance. Simply demanding that states recognize Indigenous rights does not necessarily translate into practical reforms to current practices especially without effective enforcement and dispute resolution mechanisms. In my view, effective legal and social reconciliation calls for deep systemic reforms that promote collaboration and cooperative dialogue between Indigenous peoples and states. Given the historical and ongoing transgressions against Indigenous peoples, it is not enough to simply rely upon existing structures and legal systems to achieve these ends. Moreover, the scope and complexity of the issues confronting transboundary governance demands a more organic, dynamic and cooperative approach to governance and dispute resolution than is currently offered in international water law. Karkkainen contends that "the problems are simply too complex and too dynamic" 544 to be addressed through state-based, top-down approaches to governance. Rather, effective transboundary water governance and the reconciliation of international water law and the international law of Indigenous peoples

\footnotetext{
${ }^{544}$ Karkkainen, supra note 249 at 77. At 78, Karkkainen continues: "The up-shot is that conventional fixedrule approaches - commands by sovereign to subject, or rules of mutual obligation owed by sovereign states to other states - turn out to be extremely blunt, limited, and inflexible tools that are poorly matched to the subtle, complex, and ever-changing demands of ecological management."
} 
require the creation of new institutions and equitable processes that promote mutual respect in transboundary water governance.

River basin organizations (RBOs) offer a template for the development of transboundary institutions and processes aimed at ensuring that Indigenous peoples are engaged in the governance of transboundary rivers. Mock defines river basin organizations as, "forums where governments that share rivers can come together to coordinate activities, share information, and develop integrated management approaches". 545 I contend that future international water initiatives should be directed towards (a) ensuring that river basin organizations are established on every transboundary river and (b) articulating the values and principles that will guide the development of these organizations. In this manner, new international institutions and principles could be co-created with Indigenous peoples in a manner that fully reflects their status as members of the international community.

Transboundary river basin organizations (RBOs) already exist on transboundary basins throughout the world as a venue for multi-stakeholder dialogue, information sharing, knowledge transfer, coalition-building and dispute resolution. Existing river basin organizations created by state agreements include the Mekong River Commission (1957), the Indus River Commission (1960), and the Nile River Basin (1999). ${ }^{546}$ The latter provides a framework for the equitable sharing of water among 10 countries and 160 million people. ${ }^{547}$ However, RBOs are not established on all transboundary rivers. While there are approximately 260 transboundary rivers in the world, the International

\footnotetext{
${ }^{545}$ Gregory Mock, “Transboundary Environmental Governance: The Ebb and Flow of River Basin Organizations" (2003), online: EarthTrends <http://earthtrends.wri.org/text/environmentalgovernance/feature-46.html> [Mock].

${ }^{546} \mathrm{UN}-$ Water, supra note 2.

${ }^{547}$ Mock, supra note 545.
} 
Network of Basin Organizations lists only 134 member organizations. ${ }^{548}$ Neither the Columbia River nor the Tsangpo-Brahmaputra River has a dedicated transboundary river basin organization.

RBOs offer the potential to create institutional capacity, which allows multiple communities and stakeholders to develop integrated basin-wide governance strategies. They also provide capacity to coordinate and disseminate the vast amount of information needed to address basin-wide issues such as the impacts of climate change, hydro-power, flooding, pollution, water scarcity and seismic activity. Most importantly, they provide the neutral space required to facilitate cross-cultural dialogue, coalition building, and collaborative problem solving that transcend the sovereign discourse. ${ }^{549}$

RBOs are a well-documented subject of international water governance, but further research is required to assess their potential to recognize the rights of Indigenous peoples. The effectiveness of RBOs varies widely and their success is dependent to a large extent on the amount of authority vested in them by states and the establishment of adequate enforcement mechanisms. ${ }^{550}$ Success is also dependent upon the level of cooperation and participation by the states in the region. For example, the Mekong Commission has been weakened by China's refusal to participate in the Mekong Commission and by the "diverse political agendas" of the other states in the region. ${ }^{551}$ Mock notes that "[e]xperience shows that when divisions among basin countries are likely to be a major obstacle, appointment of a neutral and independent chairperson to the

\footnotetext{
${ }^{548}$ See generally the International Network of Basin Organizations, online: 〈http://www.inbo-news.org/>.

${ }^{549}$ Mock, supra note 545.

550 Ibid.

551 Ibid.
} 
commission can facilitate decision-making. " 552 Another key element of successful RBOs is the inclusion of mechanisms to promote public participation, transparency and accountability. ${ }^{553}$ Current comparative research on RBOs reveals the key elements of success. Further comparative research of RBOs is required from an Indigenous perspective to establish criteria for an international declaration or convention regarding RBOs that recognizes the rights of Indigenous peoples.

The idea of an international instrument to mandate regional watercourse organizations is not new. Brown \& Odeh propose a Global Transboundary Watercourse and Aquifer Agreement (GTWAA) to create a global watercourse agreement intended to establish a river basin organization for each international transboundary watercourse and aquifer. $^{554}$ The authors contend that the creation of a GTWAA is required to address the following three shortcomings of current transboundary watercourse governance:

(i) absence of watercourse and aquifer institutions and organizations for every international WAA [watercourses and aquifers];

(ii) limited knowledge transfer of WAA governance, particularly between states with established international watercourse agreements and those without prior relationships or agreements; and

(iii) insufficient dialogue and research on potential benefits from cooperation around international WAA management, especially in light of the discussion to date that has focused almost exclusively on the economic costs of joint management. ${ }^{555}$

The authors envision a GTWAA that mandates the creation of a regional watercourse agreement on every transboundary watercourse with reference to "fundamental principles, implementation activities, and soft law, or guiding principles, to which each signatory subscribes" as well as a basin-wide commission which then implements the

\footnotetext{
552 Ibid.

${ }^{553}$ Ibid. Mock cites the Murray-Darling Basin Commission and Nile Basin Initiative as examples of successfully participatory mechanisms.

${ }_{554}$ Brown \& Odeh, supra note 9.

555 Ibid at 1 .
} 
agreement. ${ }^{556}$ Each agreement could then be adapted to regional values and considerations. In support of their proposal, the authors provide a detailed analysis of the current literature and case examples to demonstrate how the creation of institutional space is critical to aid in cooperation and reduce conflict. They contend that the guiding principles of a GTWAA include the following: (i) capacity building; (ii) communication; and (iii) balancing integrated water resource management with human needs. ${ }^{557}$ They also call for regional agreements that create effective mechanisms for dispute resolution and compliance. ${ }^{558}$

I agree with their central thesis that there is need for an international agreement that establishes a watercourse institution on every transboundary watercourse. However, their proposal fails to recognize the role that Indigenous peoples must play in the development of these agreements and organizations and to that extent it requires critical analysis from Indigenous perspectives to ensure that Indigenous rights are recognized at every level of development. Further research of RBOs is required to demonstrate the extent to which existing organizations have engaged Indigenous peoples in transboundary river governance and Indigenous peoples' experience of these organizations. Brown \& Odeh's proposal for a reconstruction of international water law merits consideration for its potential as a vehicle for implementing Indigenous rights and values in transboundary river basin agreements. A comparative analysis of the role and degree of engagement with Indigenous peoples in current RBOs will provide valuable insight into future international developments in this regard.

In my view, the codification of RBOs provide a natural forum for the legal

reconciliation that is required between international water law and the existing body of Indigenous and human rights laws. Such an approach would not attempt to challenge sovereignty but would instead aim to create an additional inclusive dimension to current state strategies. Dixon agrees, "practical coordination at the global level is needed" in the

\footnotetext{
${ }_{556}^{55 b i d}$ at 2 and 4.

${ }^{557}$ Ibid at 17-18.

${ }^{558}$ Ibid at 19.
} 
form of a "global regime framework managed by a permanent and specified global organization or secretariat" ${ }^{559}$ She concludes:

All of this implies the need for a multi-level system of governance that works above, below and with states. The UNDP itself stresses this, building partnerships at all levels of governance, from local to NGO and state actors and creating "linkages between the political processes, development challenges, and environmental management in transboundary river basins." This multi-level governance is becoming more common and more possible through globalization and the emergence of non-state actors as "states are too large to solve some local and regional problems, and too small to address some global challenges." especially for "the economic, political or ecological issues linked to water resources." This does not diminish the importance of national level governance, but the fact that "more and more actors are being included in policy formulation, in the implementation, as well as in monitoring and compliance" indicates that states are willing to share the responsibility of governance and recognize the legitimacy of actors working at different levels. ${ }^{560}$

Dixon advocates for an international institution, such as UN-Water, or another newly created UN institution, to be responsible for the coordination, implementation and enforcement of principles for transboundary water management. She further argues that it is possible to create general principles and dispute resolution mechanisms while still allowing for regional diversity. ${ }^{561}$

The creation of a "multi-level system of governance" $" 562$ is consistent with Parlett's analysis of how systemic changes to the international legal system evolve in response to particular problems. ${ }^{563}$ Parlett observes:

... new developments in the international legal system can be seen to have resulted in a series of grafts onto the existing structure of the international legal system, rather than a replacement of the existing structure. Thus, the international legal system has developed multiple structural devices which can

\footnotetext{
${ }^{559}$ Dixon, supra note 543 at paras 1 and 37.

${ }^{560}$ Ibid at para 38 .

${ }^{561}$ Notably, Dixon, ibid, at para 31, mentions the importance of incorporating the human right to water but does not acknowledge Indigenous peoples' rights.

${ }^{562}$ Dixon, ibid at para 38.

${ }^{563}$ Ibid.
} 
be used in a particular situation to address particular problems. In any given situation, more than one structural device may offer possible answers to those problems. ${ }^{564}$

In my view, there is considerable merit to the creation of new international instruments that articulate the guiding values and principles of international water law and call for the creation of RBOs on every transboundary river. Even at the regional level, it would be advantageous for Indigenous peoples to demand that states' enter into bilateral and multilateral agreements for the creation of a river basin organization for the purposes of coalition building, information gathering and dispute resolution.

The creation of such transboundary institutions would be consistent with the requirements of Article 32 of ILO No 169 regarding the requirement upon states "to facilitate contacts and co-operation between indigenous and tribal peoples across borders" ${ }^{565}$ while also providing states with the institutional capacity to meet their domestic and international obligations to engage in genuine dialogue with Indigenous peoples to garner their "free and informed consent". Well-crafted dispute resolution mechanisms could also alleviate lengthy and costly court actions at the national and international level. Even in regions where one or more states refuses to participate in the RBO, which is likely where China is concerned, there would be distinct advantages in creating a transboundary institution to provide other states, international agencies and Indigenous peoples with an opportunity to work collectively to overcome the challenges of such non-cooperation. ${ }^{566}$

\footnotetext{
${ }_{564}^{56}$ Parlett, supra note 456 at 366.

${ }_{565}^{56}$ ILO No 169, supra note 504 at Art 32.

${ }^{566}$ For example, the Mekong River Commission has reported some success in engaging China in information sharing and negotiations despite China's refusal to join the Commission. See for example, UN Econ \& Soc Council, Report of the Mekong River Commission, E/ESCAP/63/31, UN ESCOR, 23 March 2007. Also see McCaffrey (2007), supra note 5 at 456-457.
} 
The creation of such an institution whether globally or regionally, requires the full participation of Indigenous peoples at every level of development if it is to achieve its full potential to further cooperation and reduce conflict over water. ${ }^{567}$ In the next section, I will consider how an international instrument mandating RBOs on every transboundary river could promote the reconciliation of international water law and international law of Indigenous peoples.

\subsection{River Basin Organizations as "Ethical Spaces"}

... the idea of the ethical space, produced by contrasting perspectives of the world, entertains the notion of a meeting place, or initial thinking about a neutral zone between entities or cultures. The space offers a venue to step out of our allegiances, to detach from the cages of our mental worlds and assume a position where human-to-human dialogue can occur. The ethical space offers itself as the theatre for cross-cultural conversation in pursuit of ethically engaging diversity and disperses claims to the human order. ${ }^{568}$

Willie Ermine, Cree Ethicist

Space must be created, intellectually and socially for peace to be achieved. ${ }^{569}$

Taiaiake Alfred, Kahnawá:ke, Mohawk Nation

The creation of an international instrument that mandates the formation of a river basin organization on every transboundary river holds the most potential for promoting the genuine reconciliation of international water law and the international law of Indigenous peoples. The creation of new basin-wide transboundary river institutions

\footnotetext{
${ }^{567}$ Notably, when the Amazon Cooperation was signed by the states along the Amazon Basin without the participation of Indigenous peoples, the Indigenous peoples of nine Amazon states created their own transboundary river organization, Coordinator of Indigenous Organizations of the Amazon Basin (COICA), to provide a framework for integrating their organizations and "to unite and organize in the defense of our rights as peoples". See Coordinator of Indigenous Organizations of the Amazon Basin (COICA). "Our Organization" online: COICA <http://www.coica.org.ec/ingles/organization/index.html>.

${ }^{568}$ Ermine (2007), supra note 45 at 202.

${ }^{569}$ Alfred (2005 Wasáse), supra note 117 at 266.
} 
built upon "post-imperial values" such as "consent, mutual recognition, and cultural continuity ${ }^{970}$ provides an opportunity for Indigenous and non-Indigenous peoples to engage in addressing some of the complexities of shared water governance while simultaneously allowing for a departure from the sovereignty discourse, at least on a 'without prejudice' basis.

Cree ethicist, Willie Ermine, calls for the creation of "ethical spaces" as a critical first step in the reconciliation of Indigenous and non-Indigenous peoples. In describing "ethical spaces", he states:

Engagement at the ethical space triggers a dialogue that begins to set the parameters for an agreement to interact modeled on appropriate, ethical and human principles. Dialogue is concerned with providing space for exploring fields of thought and attention is given to understanding how thought functions in governing our behaviours. It is a way of observing, collectively, how hidden values and intentions can control our behaviour, and how unnoticed cultural differences can clash without our realizing what is occurring. ${ }^{571}$

If thoughtfully constructed in a manner consistent with the guiding principles set out in UNDRIP, river basin organizations could provide the neutral "ethical" meeting space necessary for coalition building to occur on the specific issues confronting shared transboundary water governance. As Ermine states, "[t]he compelling legal task is to enable processes so that rights are justly named, described and understood." ${ }^{, 572}$

The process of co-creating an international instrument to guide river basin organizations will require states and Indigenous groups to reach some consensus on the articulation of the underlying values and principles that should guide water governance.

\footnotetext{
${ }^{570}$ Ibid.

${ }_{572}^{571}$ Ermine (2007), supra note 45 at 202-203.

572 Ibid at 201.
} 
Pradhan et al. consider the nexus between the identification of values and legal right to water:

Rights to resources derive from law, which in turn has a dialectical relationship with underlying cultural values, such as those of justice, equity, solidarity, and hierarchy, on one hand, and cultural meanings and values of resources on the other. ${ }^{573}$

The authors conclude,"[c]laims to and recognition of claims over resources are based not only on specific laws, principles, and rules, but also on wider cultural norms and values." $^{\text {574 }}$ Increasingly, there is a call to articulate and implement international water ethics into international water laws. The United Nations Educational, Scientific and Cultural Organization (UNESCO) issued a report in 2011 entitled Water Ethics and Water Resource Management in which it concluded that "[g]iven the realities of the global water stress crisis, we need to adapt acceptable frameworks of environmental ethics to water resource management." ${ }^{575}$ The authors cite the adoption of the Universal Declaration of Bioethics and Human Rights $[U D B H R]^{576}$ by all members of UNESCO in 2005 as well as the World Commission on the Ethics of Science and Technology [COMEST] report entitled Best Ethical Practice in Water Use and identify several ethical principles that have evolved into internationally accepted norms including the principles of human dignity, human equality, equity, inclusiveness and participation among others. While the report does not mention the collective rights of Indigenous peoples, it

\footnotetext{
${ }^{573}$ Rajendra Pradhan, Ruth Meinzen-Dick, Ruth Suseela, "Which Rights are Right? Water Rights, Culture, and Underlying Values" in Peter G Brown \& Jeremy J Schmidt, eds, Water Ethics: Foundational Readings for Students and Professionals (Washington, D.C.: Island Press, 2010) 39 at 40 [Brown \& Schmidt]. 574 Ibid at 43.

${ }^{575}$ Liu, Jie et al. "Water Ethics and Water Resource Management" an Ethics and Climate Change in Asia and the Pacific (ECCAP) Project, Working Group 14 Report (Bangkok: UNESCO, 2011) [Liu]. For further reading on the emerging role of water ethics see Peter G Brown \& Jeremy J Schmidt, eds, Water Ethics: Foundational Readings for Students and Professionals (Washington, DC: Island Press, 2010).

${ }^{576}$ Universal Declaration of Bioethics and Human Rights, adopted at UNESCO's General Conference, 19 October 2005, online: UNESCO < http://portal.unesco.org/en/ev.php-

URL_ID=31058\&URL_DO=DO_TOPIC\&URL_SECTION=201.html> [UDBHR].
} 
emphasizes the need to develop the field of water ethics in order to address the realities of the "global water stress crisis." Indigenous values regarding water must start with recognition of Indigenous peoples' laws, traditions and recommendations regarding a shared international water ethic. ${ }^{578}$ While the $U D B H R$ provides a declaration on water ethics from a state perspective, further analysis and synthesis of Indigenous declarations on water is required to identify water laws and ethics that may be unique to Indigenous peoples. ${ }^{579}$ Groenfeldt (2010) notes that the development of an international water ethic "would not fill a void, but would rather replace ethical systems already in effect." ${ }^{, 580}$ Ethics are already implicit in international water law regarding the rights of Indigenous peoples, the doctrine of sovereignty and the factors that are deemed relevant to decisions regarding transboundary waters. The process of co-creating an international declaration on water ethics that can be supported by both states and Indigenous peoples will make the discussion of ethics explicit and provide the foundation for new laws and legal systems.

An international commitment to river basin organization could create the space and institutional capacity necessary for the exploration and reconciliation of state and

\footnotetext{
${ }^{577}$ Liu et al, supra note 575 at 52.

${ }^{578}$ This process will also require reconciliation of anthropocentric versus bio-centric views as well. While Indigenous peoples' interests and values are often aligned with environmental needs, it would be a mistake to assume that Indigenous peoples' interests would necessarily protect the environment. See generally, Benjamin J. Richardson, "The Ties that Bind: Indigenous Peoples and Environmental Governance" in Richardson et al, supra note 275, 337 [Richardson (2009)]. A discussion of environmental ethics is beyond the scope of this paper but will necessitate further analysis in the development of an international water ethic. See for example, Bolivia's proposal to the United Nations to grant the Earth rights on par with humans. See Jane Gleeson-White, "Extreme weather and Mother Earth: nature gets legal rights in Bolivia" Overland (17 June 2011), online: Overland < http://overland.org.au/2011/06/extreme-weather-and-motherearth-nature-gets-legal-rights-in-bolivia/>.

${ }^{579}$ For examples of Indigenous peoples' statements on water, see Appendix A: Indigenous Water Declarations \& Recommendations.

${ }^{580}$ David Groenfeldt, "Viewpoint - The Next Nexus? Environmental Ethics, Water Policies and Climate Change" in (2010) 3:3 Water Alternatives 575, online: Water Alternatives $<$ http://www.wateralternatives.org/index.php?option $=$ com docman\&task $=$ doc download\&gid=11 $>$ at 576 [Groenfeldt (2010)].
} 
Indigenous values regarding water and stimulate the co-creation of a shared international water ethic. This water ethic would then inform the principles that will guide institutional processes such as the mechanics of dispute resolution, participatory processes and information sharing.

Transboundary river basin organizations offer a regional forum for the development of basin-wide dispute resolution mechanisms. One of the most common criticisms of the current UN Watercourse Convention is its failure to provide any dispute resolution mechanisms for non-state actors regarding transboundary development. While some Indigenous peoples may have recourse to domestic courts, many national systems are still inadequate to address Indigenous peoples' claims and the rising level of domestic water conflicts. ${ }^{581}$ Courts are also often inadequate to address the extraterritorial character of transboundary disputes. To the extent that court remedies are limited to compensation or reparation, they are arguably inadequate. ${ }^{582}$ Within the context of environmental degradation, McCaffrey notes that even the International Court of Justice (ICJ) recognizes "that traditional remedies for the breach of international obligations are often of little use where the environment is concerned" ${ }^{883}$ McCaffrey cites the ICJ in the Gabčíkovo-Nagymaros case as follows:

The Court is mindful that, in the field of environmental protection, vigilance and prevention are required on account of the often irreversible

\footnotetext{
${ }^{581}$ Even where national courts are adequate to address the issues, Indigenous peoples often face resource barriers to accessing the courts.

${ }^{582}$ See James (Sa'ke'j) Youngblood Henderson, Indigenous Diplomacy and the Rights of Peoples: Achieving UN Recognition (Saskatoon, Canada: Purich Publishing Ltd, 2008) at 92. Henderson states, "The courts are not the answer to the realization of the human rights of Indigenous peoples.... The legal documents and the courts play a limited role, but the ultimate answer is political. The courts cannot do the political work of self-determining people. Indigenous peoples must understand that the implementation of our human rights and fundamental freedoms is the art of politics."

${ }^{583}$ McCaffrey (2007), supra note 5 at 453.
} 
character of damage to the environment and of the limitations inherent in the very mechanism of reparation of this type of damage. ${ }^{584}$

Given the interconnectedness and synergy between the environment and Indigenous rights, the recognition of Indigenous rights in transboundary disputes requires regional dispute resolution mechanisms that also addresses the "irreversible character" of damage to Indigenous communities. Priority needs to be placed on collaboration and coalition building prior to development. Established processes for coalition building would also provide sovereigns with an opportunity to meet their international and domestic obligations to consult with and obtain the "free and informed consent" of Indigenous populations prior to development on transboundary rivers.

Participatory processes could also allow for recognition of the full spectrum of diverse Indigenous perspectives, thereby avoiding the tendency to assume that there is only one Indigenous perspective on any given issue. Richardson states:

... international environmental law affirms the need for effective participation of indigenous peoples in determining how to achieve sustainability. Enduring solutions to this challenge are unlikely to be found if policy reform is framed solely in terms of enunciating indigenous rights over use of plants and animals. Rather, the focus should be broadened to require the establishment of institutional processes that secure indigenous peoples' involvement in environmental decision-making systems in an integrated and proactive manner. This should be accompanied by a shift away from prevailing monocultural approaches to resource management to the forging of new crosscultural strategies that allow for interaction rather than conflict between indigenous and non-indigenous interests. ... The environmental challenge is one that requires governments, communities, indigenous peoples and others to cooperate and employ new legal concepts and institutions. ${ }^{585}$

\footnotetext{
${ }^{584}$ Gabčíkovo-Nagymaros, supra note 89; McCaffrey, ibid.

${ }^{585}$ Benjamin J Richardson, "Indigenous Peoples, International Law and Sustainability" (2001) 10 RECIEL 1 at 11-12 [Richardson (2001)].
} 
While critics will contend that it is not possible to allow everyone a seat at the table, major multi-stakeholder environmental agreements provide evidence that large multiparty negotiations regarding the environment are possible. ${ }^{586}$

River basin organizations could also provide the institutional capacity to coordinate a vast amount of information regarding the entire river basin including scientific data on climate change, fluctuation levels, seismic activity, and flooding. Moreover, they provide the opportunity for knowledge transfers as well as the potential to learn from Indigenous peoples' traditional knowledge regarding governance strategies in times of water scarcity. ${ }^{587}$ Wolf identifies the wealth of untapped traditional knowledge that exists regarding Indigenous strategies for shared water governance in arid regions throughout the world. ${ }^{588}$ His research considers lessons learned from the methods of conflict resolution adopted by the Berbers of the High Atlas Mountains and the Bedouin of the Negev Desert, in the face of water scarcity and fluctuation. ${ }^{589}$ Similarly Professor Alfred (2005) observes the potential for international law to learn from Indigenous traditions:

Scholars of international law are now beginning to see the vast potential for peace represented in indigenous political philosophies. Attention focused on the principles of the Rotinohshonni Kaienerekowa (Great Law of Peace) in the international arena, for example, suggests the growing recognition of indigenous thought as a postcolonial alternative to the state sovereignty $\underline{\text { model. }}^{590}$

\footnotetext{
${ }^{586}$ For an example of international multi-party negotiations see generally, the Nile Basin Initiative, online: <http://www.nilebasin.org/newsite/>; and see Patrick Armstrong, "Conflict Resolution and British Columbia's Great Bear Rainforest: Lessons Learned 1995-2009" (3 August 2009), online: Coast Forest Conservation Initiative <http://www.coastforestconservationinitiative.com/pdf7/GBR_PDF.pdf>.

${ }^{587}$ See generally, UN University, Traditional Knowledge and Water Management, United Nations University, Institute of Advanced Studies, Traditional Knowledge Initiative, online: UN Traditional Knowledge Initiative <http://www.unutki.org/default.php?doc_id=14>.

${ }^{588}$ Wolf, supra note 260.

${ }^{589}$ For example, Wolf, ibid, observed that the Berbers of the High Atlas Mountains resolved conflicts over water by allocating water in units of time rather than in units of volume in order to address seasonal fluctuations in flow.

${ }^{590}$ Alfred (2005), supra note 40 at 47.
} 
RBOs could become a natural forum for further understanding of Indigenous legal systems and customs regarding water governance.

The preliminary research and drafting of an international agreement to guide river basin organizations demands the full participation and support of international Indigenous institutions such as the UN Permanent Forum of Indigenous Issues or the Expert Mechanism on the Rights of Indigenous Peoples in order to ensure that it is founded upon the basis of mutual respect and that its guiding principles are consistent with Indigenous peoples' rights and values. The sincerity of any attempt at collaboration between states and Indigenous peoples is likely to be questioned in light of states' long colonial history and current practices. In "Rethinking Collaboration: Working the Indigene-Colonizer Hyphen" (2008), Jones interrogates "the logic of ([her] own) White/settler enthusiasm for dialogic collaboration" and considers the potential for exploitation in any collaborative undertaking between Indigenous and non-Indigenous peoples:

The liberal injunction to listen to the Other can turn out to be access for dominant groups to the thoughts, cultures, and lives of others.... In attempting, in the name of justice and dialogue, to move the boundary pegs of power into the terrain of the margin-dwellers, the powerful require those on the margins not to be silent, or to talk alone, but to open up their territory and share what they know. The imperialist resonances are uncomfortably apt. ${ }^{591}$

If river basin organizations are to be the "ethical spaces" imagined by Willie Ermine, then they must be co-created with the critical engagement and full participation of Indigenous peoples.

\footnotetext{
${ }^{591}$ Alison Jones, with Kuni Jenkins "Rethinking Collaboration: Working the Indigene-Colonizer Hyphen" in Norman K Denzin, Yvonna S Lincoln and Smith (2008), supra note 28, 471 at 480 . Also see page 481 where the Jones states, “. .. it is unsurprising that indigenous scholars or researchers might be cautious about collaboration and dialogue with members of colonizer groups. If shared talk becomes an exercise only in making themselves more understandable or accessible to colonizer groups, with no commensurate shifts in real political power, then it becomes better to engage in strengthening the internal communication and knowledge, as well as self-reliance, of the people."
} 


\subsection{Conclusion}

Water is a classic common property resource.

No one really owns the problem.

Therefore, no one really owns the solution. ${ }^{592}$

\section{Ban Ki-moon, UN Secretary General}

In this chapter, I have argued for the reconstruction of international law of transboundary watercourses in a manner that is inclusive of Indigenous peoples' affirmed rights. To this end, I have set out to counter potential arguments that the international legal system is limited to state actors and not flexible enough to recognize the inherent rights of Indigenous peoples. Historical analysis of the evolution of international Indigenous rights and the international legal system's recognition of the rights onto nonstate actors illustrates the flexibility of the international system to allow for such rights. However, it also points to the system's rigid adherence to the doctrine of sovereignty. From a state perspective, there exists a need for states' agreement to "confer" new rights onto Indigenous peoples. Arguably, from Indigenous perspective, it is not necessary to argue for the creation of new rights under international law but rather it is a matter of arguing for the recognition and implementation of pre-existing Indigenous rights within the context of international water law. While historical and theoretical arguments for reform are evident, systemic change of the international system tends to occur within the context of complex problems that require creative solutions. States continue to be the dominant actors in international law and state consent is required to recognize the rights of non-state actors, however, there is ample precedent that states and international agencies overwhelmingly support the implementation of Indigenous peoples' rights

\footnotetext{
${ }^{592}$ UN News Centre, "Ban Ki-moon warns that water shortages are increasingly driving conflicts" (6 February 2008), online: UN <http://www.un.org/apps/news/story.asp?NewsID=25527>.
} 
throughout the international legal system. In addition to human rights instruments and declarations that affirm express or indirect individual rights to water, UNDRIP, ILO No 169 and a multitude of other international instruments affirm Indigenous peoples' collective rights to water.

I have offered several proposals for a reconstruction of the international law of transboundary rivers that is inclusive of these rights. First, I consider the potential for an amendment to the current $U N$ Watercourse Convention to reference the human right to water and UNDRIP in order to ensure that Indigenous peoples' have the right to "free and informed consent" prior to developments that will impact their territories. This approach has limited appeal given that the $U N$ Watercourse Convention has not yet been ratified and that this limited reform perpetuates Indigenous peoples' dependence upon states to enforce their rights. Second, I consider the value of having states voluntarily insert provisions regarding the human right to water and Indigenous peoples' rights in their state agreements. This approach has merit as it would make such requirements contractually mandatory and help advance the argument that these principles have advanced into customary international law. However, it fails to provide Indigenous peoples with access to compliance or dispute resolution mechanisms. Third, I propose a radically inclusive approach to transboundary water law that envisions a new international instrument, which calls for the creation of river basin organizations on all transboundary rivers. These organizations would provide the institutional capacity that is required to ensure that integrated, holistic, basin-wide approaches to river governance are implemented in a manner that is consistent with human rights and Indigenous rights. 
Given that individual and collective rights to water are already set out under human rights laws and being addressed in human rights bodies, ${ }^{593}$ it is reasonable to question why reconstruction of international water law is necessary given that Indigenous peoples have access to dispute resolution mechanisms through established international human rights bodies. Given the critical importance of water to human life and the complexity of the issues confronting water security in the $21^{\text {st }}$ century, it is no longer legitimate to maintain an institutional separation between international water law and human rights laws. ${ }^{594}$ The reconstruction of international water law should not simply be a matter of addressing the appropriate venue for dispute resolution, but also about creating laws, institutions and processes that ensure the engagement of Indigenous peoples' in the development of creative regional strategies towards basin-wide river governance. ${ }^{595}$ Moreover, human rights bodies are constrained in their ability to address transboundary claims. Professor Dinah Shelton, President of the Inter-American Commission on Human Rights identifies the "transboundary problem" context of Indigenous water rights:

There is a transboundary problem with which human rights bodies have difficulty, because human rights instruments generally require states to protect and ensure rights to those within their territory and jurisdiction. This limits the ability of human rights bodies to examine water problems that stem from activities outside the territory of the state, whose capacity to ensure guaranteed rights is thereby affected. ... Solutions to water needs of indigenous and local communities will require transboundary cooperation and better fact-finding. ${ }^{597}$

593 Dinah Shelton, "Water Rights of Indigenous Peoples and Local Communities" (Paper delivered to the University of Geneva, Geneva, Switzerland Conference "Freshwater and International Law: the Multiple Challenges" 7-9 July 2011, June 2011) [unpublished] [Shelton].

${ }^{594}$ Macklem, supra note 461 at 207-208.

${ }^{595}$ Richardson (2001), supra note 585 at 11-12.

${ }^{596}$ Shelton, supra note 593 at 31-32.

${ }^{597} \mathrm{Ibid}$. Further critical analysis is needed to review relevant decisions of the International Court of Justice in order to identify whether any standards for transboundary water governance in state-to-state relations impact upon the rights of Indigenous peoples. 
In addition to the constraints posed by the transboundary nature of many water claims, Indigenous peoples often lack the financial resources to engage in lengthy protracted litigation in domestic courts that is generally required prior to accessing international human rights bodies. 598

Shelton enumerates several measures that are needed to "address the water crises

from a human rights perspective":

1. Integrate human rights into development decisions - recognizing the indivisibility and equal importance of all human rights.

2. Bring the targets of development into the decision-making process as active participants

3. Adopt more democratic and transparent procedures consistent with human rights.

4. Promote accountability and capacity-building.

5. Harmonize practical and operational aspects of human rights and development without compromising the essential values of each domain.

6. Recognize human rights as ends in themselves, even if evidence-based evaluation of progress is impossible.

7. Include as a part of investment agreements and licenses for development projects the Voluntary Guidelines ${ }^{599}$ for the conduct of cultural, environmental and social impact assessments regarding developments proposed to take place on or which are likely to impact on, sacred sites and on lands and waters traditionally occupied or used by indigenous and local communities, thereby making them legally binding. 600

Richardson concurs that petitions to human rights bodies to establish Indigenous rights is not sufficient to safeguard the environment and concludes:

\footnotetext{
${ }^{598}$ Note however, that Indigenous peoples have been successful in getting exemptions from the exhaustion of domestic remedies requirements based on recognition by human rights bodies that there are no adequate or effective remedies in the domestic systems for Indigenous peoples. See Hul'qumi'num Treaty Group (Canada) (30 October 2009) IACHR, Report No 105/09, Petition 592-07, Admissibility, online: IACHR <http://www.cidh.oas.org/annualrep/2009eng/Canada592.07eng.htm>.

${ }^{599}$ Convention on Biological Diversity COP - 7, 9-20 February 2004, Decision VII/16, Annex, Seventh Ordinary Meeting of the Conference of the Parties to the Convention on Biological Diversity, 9 - 20 February 2004 - Kuala Lumpur, Malaysia, online: Convention on Biological Diversity <http://www.cbd.int/decisions/cop/?m=cop-07 > [ Akwé: Kon guidelines]. Also see Shelton, supra note 593 at 34-48 for Appendix entitled "CBD: Akwé: Kon Voluntary guidelines for the conduct of cultural, environmental and social impact assessments regarding developments proposed to take place on, or which are likely to impact on, sacred sites and on lands and waters traditionally occupied or used by Indigenous and local communities"

${ }^{600}$ Shelton, supra note 593 at 32-33.
} 
... reform must also address mechanisms by which Indigenous communities can collaborate with management institutions at other levels of economic policy-making and development planning. If Indigenous livelihoods that respect the environment are to be sustained, an Indigenous voice in local environmental governance is not enough - it must also be heard in the institutions that shape the global economy, trade, finance and other fundamental causes of environmental pressure. ${ }^{601}$

In my view, the concerns raised by Shelton and Richardson can be addressed by recognizing individual and collective rights to water in the creation of basin-wide institutions designed to increase participatory decision-making and coalition-building on transboundary rivers. Water is at the foundation of all human enterprises including agriculture, hydropower, oil \& gas, tourism, and other economic pursuits. ${ }^{602}$ As such, transboundary rivers are fertile ground for the creation of international institutions that promote inclusive decision-making and coalition building to reconcile the competing interests and values of globalization and local Indigenous communities.

River basin organizations offer the potential for institutional capacity to allow multiple stakeholders to develop basin-wide governance strategies and coordinate the vast amount of information needed to address basin-wide issues such as the impacts of climate change, hydropower, flooding, pollution, water scarcity and seismic activity. RBOs could also serve as an "ethical space" to facilitate cross-cultural dialogue, coalition-building, dispute resolution and collaborative problem-solving that transcends the sovereign discourse. River basin organizations already exist on hundreds of transboundary rivers throughout the world, but do not yet exist on all transboundary rivers. Existing RBOs have been created by voluntary regional state agreements and as such vary widely in their guiding principles and processes. A comparative study of

\footnotetext{
${ }^{601}$ Richardson (2009), supra note 578 at 370.

${ }^{602}$ Sandra Postel, "The Missing Piece: A Water Ethic" in Brown \& Schmidt, supra note 573 at 221.
} 
whether existing RBOs are adequately addressing Indigenous peoples' rights could provide valuable insight into the development of international guidelines in this regard.

The process of drafting an international agreement to guide the operation of river basin organizations will require states and Indigenous peoples to collaborate on the declaration of an internationally accepted water ethic. Writing within the context of environmental protection, Postel defines "water ethic" as "a guide to right conduct in the face of complex decisions about natural systems that we do not and cannot fully understand. ${ }^{\circ 63}$ Given that water is at the foundation of all human enterprises and all life, laws regarding water by their very nature require a consideration of ethics. Indeed, it is imperative for the international community to articulate and codify an international water ethic for the $21^{\text {st }}$ century that will guide the future development of international water law.

${ }^{603}$ Ibid at 222. Also see Ermine (2007), supra note 45, where simply defines "ethics" as "the capacity to know what harms or enhances the well-being of sentient creatures." 


\section{Chapter 5: Conclusion: A Return to Ethics}

The art and practice of equitable distribution of an access to fresh water for all people in the $21^{\text {st }}$ century, as a fundamental human right and international obligation, is the mother of all ethical questions of all transboundary natural resources of a finite nature. ${ }^{604}$

Thomas R. Odhiambo, Past President of the African Academy of Sciences

All peoples rely upon water for life. Without it, they die. Competing interests over fresh water include drinking water, hydroelectric power, fishing, irrigation, environmental needs and industrial uses. The availability of fresh water is further compromised by climate change, increasing global population, and large-scale development projects that dominate local communities and pollute freshwater supplies. The goal of water security is a matter of international importance that has political, human and environmental dimensions. Indigenous peoples are particularly vulnerable in the current global water crisis. On May 16, 2001, UN Secretary-General Ban-Ki-moon observed, "[m]illions of indigenous peoples continue to lose their lands, their rights, and their resources. They make up one third of the world's 1 billion rural poor. And they are among the most vulnerable and marginalized of any group."605 Within the context of international water law, the rights of Indigenous peoples are an issue of fundamental importance and international concern. Yet, Indigenous peoples' rights are conspicuously absent from international water laws and legal discourse.

\footnotetext{
${ }^{604}$ Thomas R. Odhiambo in Sheldon Krimsky, Water Ethics: Beyond Riparian Rights, (WSSS Seminar, 2005) as cited by Liu et al, supra note 575 at 15.

${ }^{605}$ Permanent Forum Can Play Dynamic Role in Changing Deplorable Situation of Indigenous People, Secretary-General Says at Opening Session, UN Secretary General SG/SM/13575, HR/5052 (16 May 2011), online: UN <www.un.org/News/Press/docs/2011/sgsm13575.doc.htm>.
} 
In this thesis, I have adopted Critical Race (Indigenous) Theory to confront the inequities inherent in the UN Watercourse Convention, the doctrine of sovereignty and related discourse from Indigenous peoples' perspectives. My methodology has involved: (i) adopting a theoretical framework informed by Critical Race Theory; (ii) deconstructing the UN Watercourse Convention and the legal doctrine of sovereignty and providing two case studies to illuminate Indigenous perspectives in transboundary water law; (iii) presenting a literature review regarding Indigenous peoples' relationship to the doctrine of sovereignty and alternative conceptions of sovereignty; and (iv) offering proposals for reconstructing international water law in a manner that is inclusive of Indigenous peoples and invites a return to ethics as the foundation for future reform. A discussion of ethics and the role of law in shaping the relationship between Indigenous and non-Indigenous peoples is particularly apt in the context of transboundary water law. The very nature of rivers and the dependence of all living things upon the hydrological cycle forces us to acknowledge our interconnectedness at a global level, the fragility of human life and the relative arbitrariness of state boundaries. Within this context, I have sought to engage Indigenous perspectives regarding the intersection of international water law, the doctrine of sovereignty and the international rights of Indigenous peoples.

The UN Watercourse Convention and related legal discourse is aimed solely at governing the relations between sovereigns. It is premised upon "sovereign equality" 606 and codifies equitable principles aimed at seeking optimal utilization of a shared resource in a manner that minimizes harm to downstream states. From a state-perspective, the $U N$ Watercourse Convention is perceived as a departure from the strict adherence to the doctrine of sovereignty in favour of cooperative state development agreements that

${ }^{606}$ UN Watercourse Convention, supra note 15 at Art 8(1). 
emphasize "mutual gains". However, when viewed from Indigenous perspectives, the primacy of sovereignty continues to dictate which peoples may avail themselves to the equitable principles of the Convention and operates to exclude Indigenous peoples from the legal discourse.

A critical analysis of the UN Watercourse Convention and related legal discourse demonstrates that Indigenous peoples are conspicuously absent from both. States are not held to any international standard with respect to Indigenous peoples when making agreements under the Convention. Indeed, the Convention appears to place the agreement and cooperation of states as its primary objective regardless of the agreement's impact upon the rights of Indigenous peoples. However, a review of two transboundary basins, the Columbia River and the Tsangpo-Brahmaputra, demonstrate the devastating impact of past developments upon Indigenous peoples and the potential for violent conflict in future developments. Applying Critical Race Theory to deconstruct international water law, I contend that the emphasis placed upon sovereign status in international water law may operate to adversely impact Indigenous peoples in the following ways:

(i) It excludes Indigenous peoples from international negotiations regarding transboundary rivers and from participating in the development of international water law principles;

(ii) It presumes that Indigenous peoples' interests in transboundary rivers are a domestic issue, thereby reinforcing Indigenous peoples as subordinate to the states that oppress them and perpetuating ongoing colonization of Indigenous peoples by states;

(iii) It undermines international conventions and declarations that have affirmed the rights of Indigenous peoples to fully participate in environmental decision-making; and

(iv) It may exacerbate conflict over disputed territories and unintentionally encourage states to expand their territories.

By relying solely upon states' interests and a Western classical understanding of sovereignty, international water law is predicated upon values and assumptions that 
contradict and exclude Indigenous peoples' experience of sovereignty and relationship with water.

Locating Indigenous peoples in international water law necessitates an understanding of the historical context surrounding the doctrine of sovereignty and a consideration of how Indigenous peoples experience sovereignty. By offering alternative narratives to the dominant discourse, it becomes apparent that one's understanding of sovereignty is a reflection of political, cultural and spiritual values, and one's place in the world. The following themes arose from the literature:

(i) Indigenous perspectives challenge the myths of neutrality and objectivity that surround the doctrine of sovereignty.

(ii) The conflicts surrounding sovereignty discourse are ultimately premised on a conflict of values.

(iii) There is no one universal homogenous perspective regarding Indigenous sovereignty but rather a plurality of diverse perspectives.

(iv) At their root, all the perspectives are aimed at reclaiming Indigenous sovereignty and inherent power as well as redefining Indigenous-state relations.

Indigenous narratives regarding the meaning of sovereignty invoke values that accord with duties, balance, mutual respect and interconnectedness with nature. In contrast, the Western legal concept of sovereignty evokes values of entitlement, conquest, domination over nature, territoriality, authority and power over some peoples to the benefit of other peoples. Once viewed in contrast with Indigenous ways of understanding power, the perceived neutrality and objectivity of the Western legal definition of sovereignty dissolves and it becomes apparent that the doctrine of sovereignty is a social construct designed to achieve the particular goals of colonization and exploitation of peoples and resources. ${ }^{607}$ To the extent that the doctrine of sovereignty is a cornerstone of our

${ }^{607}$ Alfred (2005), supra note 40. 
current international legal systems, Indigenous peoples continue to suffer the adverse consequences of the domination of imperialist values over Indigenous values.

According to Macklem, the international law of Indigenous peoples has emerged to specifically acknowledge and mitigate the adverse impacts of an international legal system founded upon Western sovereignty. ${ }^{608}$ A review of the history of Indigenous peoples' rights over the last century has culminated in the codification of their rights to self-determination in ILO No 169 and UNDRIP, as well as a host of other international instruments. Supported by the majority of sovereign states and international agencies, there is a concerted effort to ensure that Indigenous peoples' rights are recognized throughout the international legal system. I contend that reform of the UN Watercourse Convention is also necessary to ensure that Indigenous peoples' rights are recognized within the context of international water law and legal discourse. Arguably, a failure to implement Indigenous rights into all legal systems and institutions simply perpetuates the colonial agenda upon which they were founded.

Given that international law has historically been concerned only with state-tostate relations, some may challenge my proposed reconstruction of international water law on the basis that international law should not or cannot accommodate the recognition of non-state actors. However, historical analysis of the evolution of international Indigenous rights and the international legal system's recognition of the rights of nonstate actors demonstrates the flexibility of the international system to allow for such rights. From a state perspective, there exists a need for states' agreement to "confer" new rights onto Indigenous peoples. However, from an Indigenous perspective, it is not necessary to argue for the creation of new rights under international law but rather it is a

${ }^{608}$ Macklem, supra note 461. 
matter of arguing for the recognition and implementation of pre-existing Indigenous rights within the context of international water law. While states remain the dominant actors in international law, there is a demonstrated willingness by the majority of states and international agencies to recognize and implement Indigenous peoples' rights.

Others may challenge that a reconstruction of international water law is not necessary given that Indigenous peoples already have access to human rights laws and organizations and that these existing laws and institutions are sufficient to address any violation of their rights. However, human rights laws are intended to address the actions of states that violate the rights of their own citizens. As such, existing human rights bodies are not adequate to address transboundary claims. I have also argued that it is not sufficient to simply establish recourse for violations of rights. True legal reconciliation will require the creation of new processes and institutional capacity that emphasizes collaboration, participatory processes and information sharing.

Reform of international water law is not likely to be achieved by challenging sovereignty directly but rather by emphasizing a return to ethics and values that have informed the emergence of human rights laws and the international rights of indigenous peoples. Rather than challenge the doctrine of sovereignty, I propose the co-creation of new international instruments and institutions based on mutual respect and interconnectedness that operate in parallel with existing laws and institutions. Such a multi-dimensional, multi-level approach to governance will create space for states and Indigenous peoples to work together to address the complexities of transboundary water governance. In my view, existing river basin organizations provide a template for 
creating the institutional capacity necessary to mitigate against the adverse impacts of our current international legal system upon Indigenous peoples.

In this thesis, I have called for the reconciliation of transboundary water law and the international law of Indigenous peoples in a manner that transcends the conflict and violence inherent in the sovereignty discourse. I contend that the conflicts within the sovereignty discourse and the emerging conflicts over water are ultimately conflicts over values. The reconciliation of international water law with the international law of Indigenous peoples necessitates a reconciliation of values and a return to ethics. In my view, reform of international water law requires two steps:

(1) the articulation of an international water ethic with the critical engagement of Indigenous peoples; and

(2) the creation of institutional capacity and processes consistent with this shared international water ethic that provide an 'ethical space ${ }^{609}$ for Indigenous peoples and states to engage each other on the complex issues surrounding water.

As noted by Groenfeldt, this is not an issue of establishing ethics where none have existed before. Rather, it is a matter of making the current water ethic explicit. The current ethic of "command and control", "economically beneficial use" and "water as resources principle" is arguably incongruous with the values of Indigenous peoples and long-term environmental sustainability. ${ }^{610}$ The development of an international water ethic is intended to reveal, challenge and discuss the ethics currently informing international water law with the goal of reconciling them with the values currently

\footnotetext{
${ }^{609}$ Ermine (2007), supra note 45.

${ }^{610}$ Groenfeldt (2010), supra note 580 at 583.
} 
espoused by the international community as embodied in the laws regarding individual and collective rights.

The development of an international water ethic will require further analysis of existing international declarations on ethics such as the Universal Declaration of Bioethics and Human Rights $(U D B H R)^{611}$ as well as regional Indigenous declarations on water ${ }^{612}$ to identify shared values. This process necessitates grassroots involvement by Indigenous peoples and critical engagement by agencies such as UN Permanent Forum on Indigenous Issues and the Expert Mechanism on the Rights of Indigenous Peoples to ensure that the values of Indigenous peoples and their traditional laws are accurately represented. ${ }^{613}$ The articulation of an international water ethic can then form the foundation for the creation of a new convention on water that mandates regional river basin organizations on every transboundary river in accordance with established ethics. This convention could establish minimum criteria regarding membership, participation, dispute resolution, information sharing and enforcement mechanisms, while also allowing enough flexibility for regional diversity. In this way, new "ethical space",614 can be created based upon a shared ethic of mutual respect, equality and interconnectedness. Further research is required to facilitate the reconstruction of international water law in a manner that recognizes Indigenous perspectives. My thesis has been limited to a

\footnotetext{
${ }^{611}$ UDBHR, supra note 576.

${ }^{612}$ Indigenous values and laws are already enshrined in a number of regional and international water declarations. For examples of Indigenous peoples' statements on water, see Appendix A: Indigenous Water Declarations \& Recommendations.

${ }^{613}$ Indigenous organizations may wish to collaborate further with international agencies concerned with water that make recommendations to states and the United Nations including UN-Water (unwater.org) and the Special Rapporteur on the human right to safe drinking water and sanitation created in 2008. See Officer of the High Commissioner of Human Rights, "Special Rapporteur on the human right to safe drinking water and sanitation", online: OHCHR <http://www.ohchr.org/EN/Issues/WaterAndSanitation/SRWater/Pages/SRWaterIndex.aspx>.

${ }^{614}$ Ermine (2007), supra note 45.
} 
Critical Race Theory analysis of the law concerning transboundary rivers only.

Additional critical analysis is needed to assess the draft articles on the Law of

Transboundary Aquifers ${ }^{615}$ as well as popular water governance theories (IWRM) from

Indigenous perspectives. In addition, comparative analysis of the structures and constraints of existing RBOs from Indigenous perspectives will provide insights into the existing or potential roles of Indigenous peoples in transboundary river institutions and provide guidance for drafting international instruments regarding the implementation of RBOs in a manner consistent with the principles of UNDRIP and ILO No 169. On a more theoretical level, further consideration is warranted to consider how a "community of interests" ${ }^{, 616}$ approach to water governance might apply to an international community that is recognized to include Indigenous peoples as well as states. ${ }^{617}$ For example, can we develop the meaning of the concepts of "community" and "interests" in a manner that allows us to develop this theoretical approach within the context of an international water ethic?

Finally, there is a pressing need for more research and recognition of traditional knowledge regarding water governance. Indigenous knowledge, legal systems and ethics, especially in water-scarce regions, may provide key insights into how we address the current global water stress crisis. How have Indigenous peoples developed governance for upstream and downstream issues? What is the traditional knowledge on keeping peaceful relations over water? Traditional knowledge may provide us with

\footnotetext{
${ }^{615}$ Law of Transboundary Aquifers, supra note 43.

${ }^{616}$ McCaffrey (2007), supra note 5. See discussion of "community of interests" approach to sovereignty at page 28-29 of this thesis.

${ }^{617}$ McCaffrey (2007), ibid.
} 
practical tools in creating peaceful governance strategies. Moreover, Indigenous wisdom

reminds us of our place in the world. Nlaka'pamux lawyer, Ardith Walkem writes:

Nlaka'pamux law is an exacting law. A law that flows from the fact that we are owned by the land, by the water, that we owe our existence to the relationship of our peoples to the territories where our grandmothers, and their grandmothers before them, came into being. The land and waters have given our people life, and we are not free to disregard that relationship because of the assertion of other laws. This law is not diminished by licenses, certificates of title, or stacks of legal papers that array themselves in challenge. It is the law of our heart, our memories, a law drawn of the physical fact that the very components of our bones and marrow are comprised of the sustenance that we have taken from the land. It is a law carried forward through stories, nourished and shared through the words we speak and the actions we take. Indigenous laws are alive and not remnants from the past, and we have an obligation to follow them, and to reinvigorate them where they have become weakened. ${ }^{618}$

While the challenging discourse on the future of sovereignty is likely to continue, the current global water stress crisis requires us to move beyond sovereignty, at least on a without prejudice basis, in order to engage in a reconciliation and articulation of the values that will guide our communities in the governance of shared water.

The comforting message from history is that our values and paradigms can and do change over time. ${ }^{619}$

\footnotetext{
${ }^{618}$ Ardith Walkem, Bringing Water to the Land, (LLM Thesis: UBC, 2005) at 6-7.

${ }^{619}$ Groenfeldt (2010), supra note 580 at 576.
} 


\section{Figures}

Figure 2.1: Map of the Columbia River Basin ${ }^{620}$

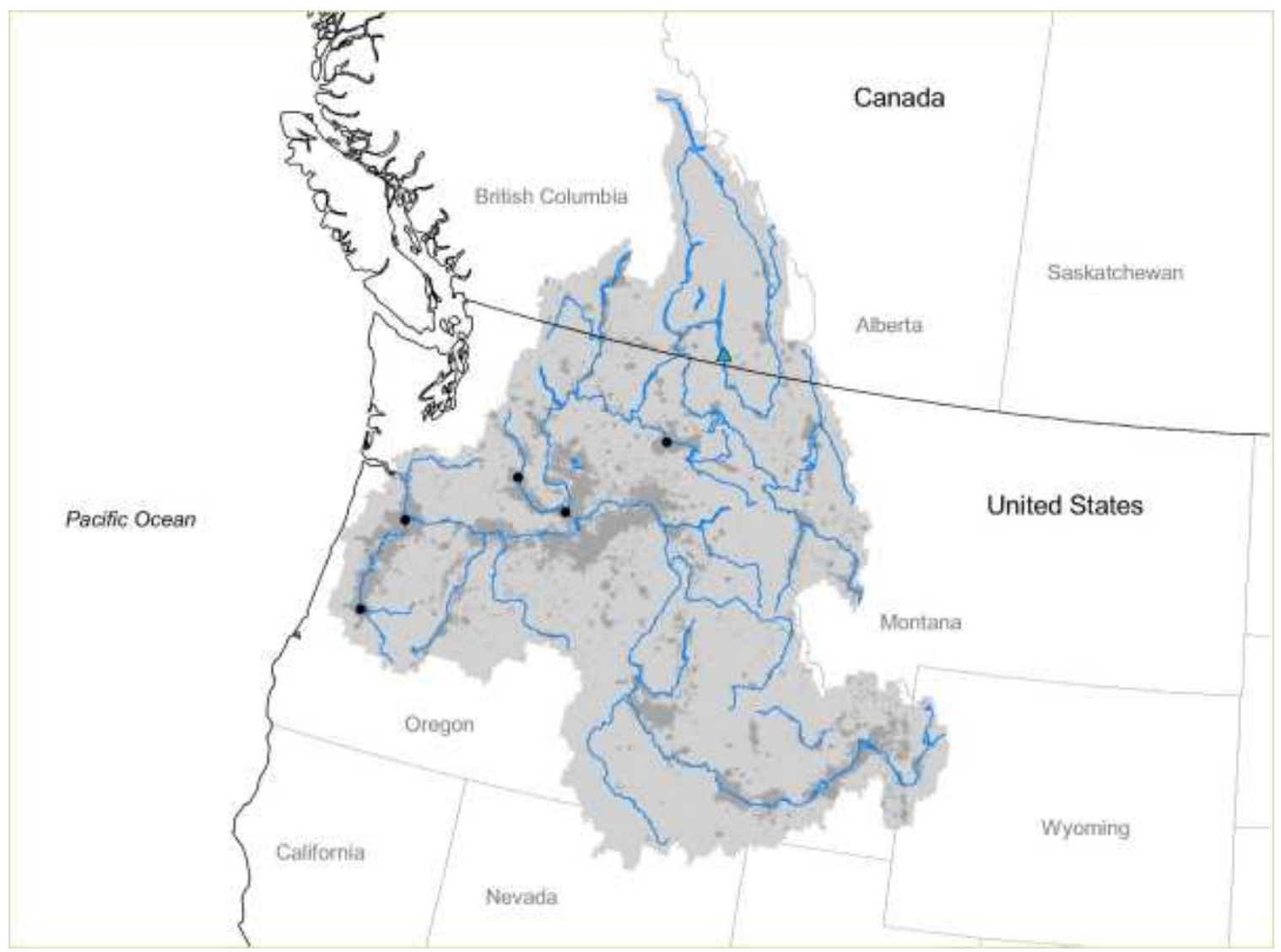

${ }^{620}$ Source: Watersheds of the World: North and Central America - Columbia Watershed () 2006 World Resources Institute <http://earthtrends.wri.org/text/water-resources/map-383.html >. Content licensed under a Creative Commons License <http://creativecommons.org/licenses/by-nc-sa/2.5/>. 
Figure 2.2: Map of Tsangpo-Brahmaputra Basin ${ }^{621}$

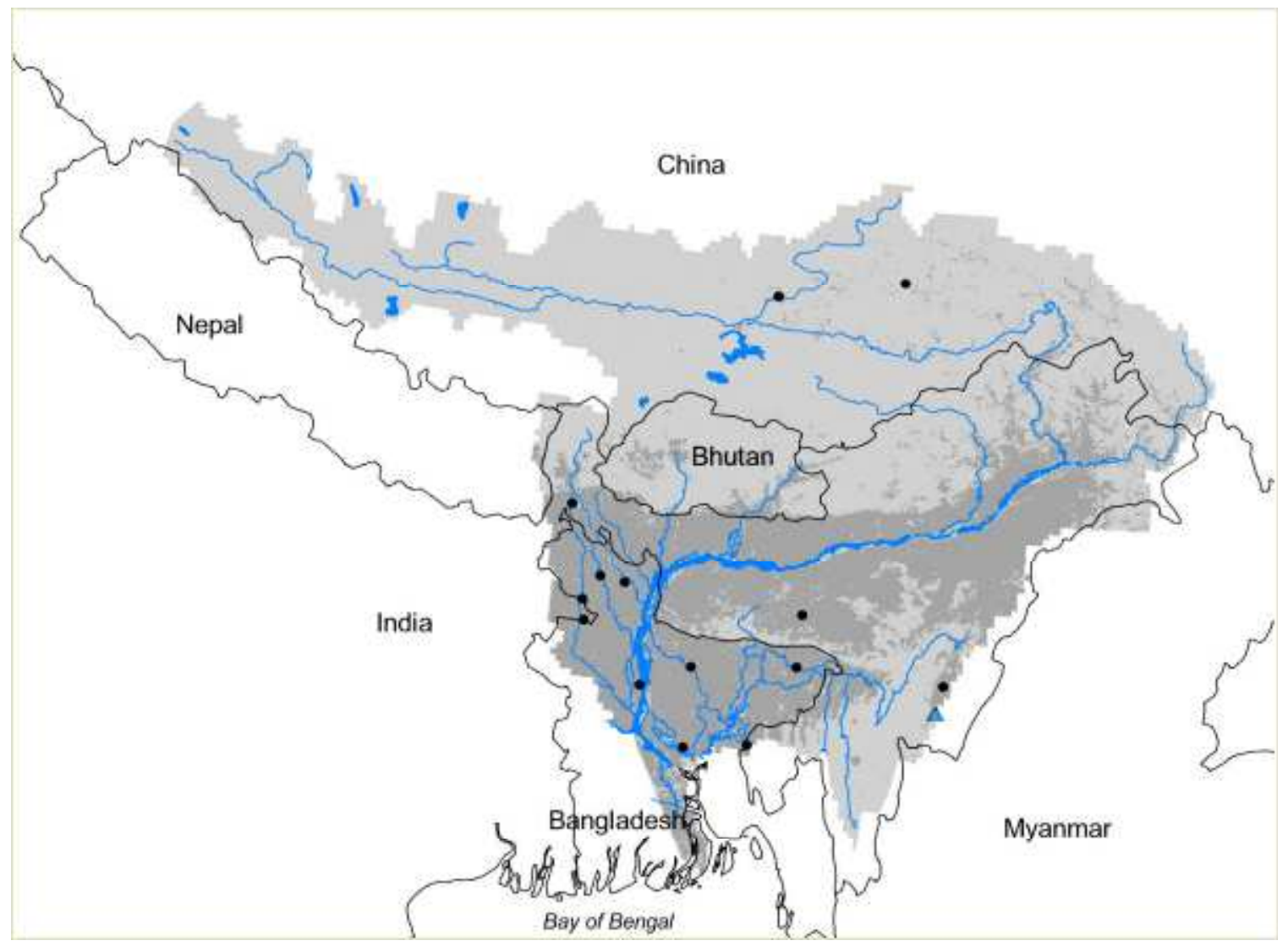

${ }^{621}$ Source: Watersheds of the World: Asia and Oceania - Brahmaputra Watershed. @ 2006 World Resources Institute. Online at: <http://earthtrends.wri.org/text/water-resources/map-347.html>. Content licensed under a Creative Commons License <http://creativecommons.org/licenses/by-nc-sa/2.5/>. 


\section{Bibliography}

\section{Legislation}

Columbia Basin Trust Act, RSBC 1996, cC-53 (Canada).

\section{Jurisprudence: Domestic}

Cherokee Nation v Georgia, 30 US 1 (1831) (US).

Chief Mountain v British Columbia (Attorney General) 2011 BCSC 1394 (Canada).

Johnson v M'Intosh, 21 US (8 Wheat) 543 (1823) (US).

Pakootas v Teck Cominco Metals, Ltd, (2006) 452 F 3d 1066 (US).

Worcester v Georgia, 31 US (6 Pet) 515 (1832) (US).

\section{Jurisprudence: International}

Case Concerning the Gabčíkovo-Nagymaros Project (Hungary/Slovakia), [1997] ICJ Judgment of 25 September 1997, International Court of Justice, online: International Court of Justice <http://www.icj-cij.org/docket/files/92/7375.pdf> [GabčíkovoNagymaros].

Case Relating to the Territorial Jurisdiction of the International Commission of the Oder River (1929), Judgment of 10 September 1929, PCIJ (Series A No 23 -Series C No 17-11), online: International Water Law, <http://www.internationalwaterlaw.org/cases/river-oder.html $>$ [Oder River].

Case of the Saramaka People v Suriname (28 November 2007), IACHR (ser C) No 172 [Saramaka People].

Hul'qumi'num Treaty Group (Canada) (30 October 2009) IACHR, Report No 105/09, Petition 592-07, Admissibility, online: IACHR <http://www.cidh.oas.org/annualrep/2009eng/Canada592.07eng.htm>.

Western Sahara, Advisory Opinion, (16 October 1975) ICJ 12, online: ICJ $<$ http://www.icjcij.org/docket/index.php?p1=3\&p2=4\&k=69\&case=61\&code=sa\&p3=4>. 


\section{International Conventions \& Treaties}

Convention on Biological Diversity COP - 7, 9-20 February 2004, Decision VII/16, Annex, Seventh Ordinary Meeting of the Conference of the Parties to the Convention on Biological Diversity, 9 - 20 February 2004 - Kuala Lumpur, Malaysia, online: Convention on Biological Diversity <http://www.cbd.int/decisions/cop/?m=cop-07 > [ Akwé: Kon guidelines].

Convention on the Law of the Non-Navigational Uses of International Watercourses, opened for signature 21 May 1997, 36 ILM 700 (1997) (not yet in force) [UN Watercourse Convention].

Covenant of the League of Nations: Article 23, Creation of Mandates, (28 June 1919) para b, on-line: African History <http://africanhistory.about.com/od/eracolonialism/qt/MandateA23.htm>.

International Covenant on Economic Social and Cultural Rights, 19 Dec 1966, 993 UNTS 3 [ICESCR].

International Labour Organisation Convention No 169 Concerning Indigenous and Tribal Peoples in Independent Countries, 27 June 1989, 1650 UNTS 383 (entered into force Sept. 5, 1991) [ILO No 169].

Report of the United Nations Conference on Environment and Development (Rio de Janeiro, 3-14 1992) Annex I Rio Declaration of Environment and Development, 3-14 June 1992, GA A/CONF.151/26 (Vol. I) [Rio Declaration]

Treaty relating to the Boundary Waters and Questions Arising along the Boundary between the United States and Canada, signed at Washington 11 January 1909, entered into force 5 May 1910, online: International Joint Commission <http://www.ijc.org/rel/agree/water.html\#text>.

\section{United Nations (UN) Documents and Publications}

Agenda 21, Report of the UNCED, I, UN CED, (1992), DocA/CONF. 15126 (Vol. II) online: United Nations

<http://www.un.org/esa/sustdev/documents/agenda21/english/agenda21 toc.htm> [Agenda 21].

General Assembly Adopts Convention on Law of Non-Navigational Uses of International Watercourses, GA Res GA/9248, UN GAOR, 21 May 1997, online: The Water Page <www.thewaterpage.com/UNPressWater.htm>.

General Assembly Adopts Resolution Recognizing Access to Clean Water, Sanitation as Human Right, by Recorded Vote of 122 in Favour, None against, 41 Abstentions, GA 
Res GA/10967, UN GAOR, $64^{\text {th }}$ Sess, $108^{\text {th }}$ Mtg (28 July 2010), online:

<http://www.un.org/News/Press/docs/2010/ga10967.doc.htm>.

General Assembly Sixty-sixth Session Summary Report: Law of transboundary aquifers (Agenda Item 85 re: Res 63/124), UN GAOR (15 January 2009), online: United Nations <http://www.un.org/en/ga/sixth/66/TransAquifer.html>.

International Labour Organization, “Convention No C169”, online: ILO < http://www.ilo.org/ilolex/cgi-lex/ratifce.pl?C169>.

---. “Convention No 169”, online: ILO <http://www.ilo.org/indigenous/Conventions/no169/lang--en/index.htm>.

International Law Commission, Draft articles on the Law of Transboundary Aquifers, (2008) UN GAOR Sixty-third Session, Supp No. 10, UN Doc A/63/10, online: UN <http://untreaty.un.org/ilc/texts/instruments/english/draft\%20articles/8_5_2008.pdf> [Law of Transboundary Aquifers].

Permanent Forum Can Play Dynamic Role in Changing Deplorable Situation of Indigenous People, Secretary-General Says at Opening Session, UN Secretary General SG/SM/13575, HR/5052 (16 May 2011), online: UN <www.un.org/News/Press/docs/2011/sgsm13575.doc.htm>.

UN Bibliographic Information System, United Nations Declaration on the Rights of Indigenous Peoples: resolution / adopted by the General Assembly, online: UN <http://unbisnet.un.org:8080/ipac20/ipac.jsp?profile=voting\&index=.VM\&term=ares $\underline{61295}>$.

UN Development Group, Guidelines on Indigenous Peoples' Issues, (2008) online: Office of the High Commissioner of Human Rights 〈http://www2.ohchr.org/english/issues/indigenous/docs/guidelines.pdf >.

UN ESCOR, General Comment No. 15: The right to water (arts. 11 and 12 of the International Covenant on Economic, Social and Cultural Rights), $29^{\text {th }}$ Sess, UN Doc. E/C.12/2002/11 (2002) [General Comment No. 15].

---. Report of the Mekong River Commission, E/ESCAP/63/31, UN ESCOR, 23 March 2007.

---. Res 1589(L), para 7, 50 ${ }^{\text {th }}$ Sess., Supp No 1, UN Doc E/5044 (21 May 1971) [Resolution 1589].

UN News Centre, "Ban Ki-moon warns that water shortages are increasingly driving conflicts" (6 February 2008), online: UN <http://www.un.org/apps/news/story.asp?NewsID=25527>. 
---. "Right to water and sanitation is legally binding, affirms key UN body" (1 October 2010), online: United Nations $<$ http://www.un.org/apps/news/story.asp?NewsID=36308\&Cr=water\&Cr1=>.

UN Office of the High Commissioner of Human Rights (OHCHR), "UN united to make the right to water and sanitation legally binding" (1 October 2010), online: OHCHR <http://www.ohchr.org/en/NewsEvents/Pages/DisplayNews.aspx?NewsID=10403\&L angID $=\mathrm{E}>$.

---. "Special Rapporteur on the human right to safe drinking water and sanitation", online: OHCHR $<$ http://www.ohchr.org/EN/Issues/WaterAndSanitation/SRWater/Pages/SRWaterInde x.aspx>.

UN Permanent Forum on Indigenous Issues [UNPFII], "IASG / Inter-Agency Support Group on Indigenous Issues", online: UN <http://www.un.org/esa/socdev/unpfii/en/iasg.html>.

---. "Inter-Agency Support Group", online: UN 〈http://social.un.org/index/IndigenousPeoples/InterAgencySupportGroup.aspx>.

---. Study of the Problem of Discrimination Against Indigenous Populations, (consolidated) UN DOC ECN4Sub.219867 and Add1-4 (28 June 1983) (prepared by José Martínez Cobo), online: United Nations <http://www.un.org/esa/socdev/unpfii/en/spdaip.html> [Martínez Cobo Report].

---. "United Nations Declaration on the Rights of Indigenous Peoples Adopted by the General Assembly 13 September 2007”, online: United Nations <http://www.un.org/esa/socdev/unpfii/en/declaration.html>.

UN Treaty Collections, "Convention on the Law of the Non-Navigational Uses of International Watercourses New York, 21 May 1997" (Status as at 2 January 2012), online: UN Treaty Collections <http://treaties.un.org/Pages/ViewDetails.aspx?src=UNTSONLINE\&tabid=2\&mtdsg $\_$no=XXVII-12\&chapter=27\&lang=en\#Participants>.

UN University, Deep Words, Shallow Words: An Initial Analysis of Water Discourse in Four Decades of UN Declarations, report from the UNU Institute for Water and Health, (October 2011), online: United Nations University <http://www.inweh.unu.edu/River/documents/DeepWords_ShallowWords\%20_Mou nt\&Bielak_FINAL_pdf_Oct_26_2011.pdf>.

---. Traditional Knowledge and Water Management, United Nations University, Institute of Advanced Studies, Traditional Knowledge Initiative, online: UN Traditional Knowledge Initiative <http://www.unutki.org/default.php?doc_id=14>. 
UN-Water, Transboundary Waters" UN International Decade of Action, Water for Life 2005-2015, online: UN

<http://www.un.org/waterforlifedecade/transboundary_waters.shtml $>$.

United Nations Declaration on the Rights of Indigenous Peoples, UN GAOR

Doc.A/RES/61/295 (13 September 2007) online: UN

$<$ http://www.un.org/esa/socdev/unpfii/en/declaration.html $>$ [UNDRIP].

Universal Declaration of Bioethics and Human Rights, adopted at UNESCO's General Conference, 19 October 2005, online: UNESCO < http://portal.unesco.org/en/ev.php-

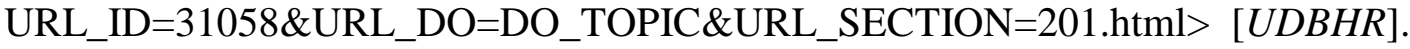

Universal Declaration of Human Rights, GA Res 217 (III), UN GAOR, 3d Sess, Supp No 13, UN Doc A/810 (1948) [UDHR].

\section{Secondary Materials}

Aboriginal Affairs and Northern Development Canada, Canada's Statement of Support on the United Nations Declaration on the Rights of Indigenous Peoples, online: Aboriginal Affairs and Northern Development Canada < http://www.aadncaandc.gc.ca/eng/1309374239861>.

Adams, Howard. "The Process of Neocolonialism, excerpt from Tortured People: The Politics of Colonization, Ch. 8 (Theytus Books, 1999) as reprinted in Robert Odawi Porter, ed Sovereignty, Colonialism and the Indigenous Nations: A Reader (Durham, North Carolina: California Academic Press, 2005) 497.

Akwesasne Notes. "Indigenous Peoples, Self-Determination and the Unfounded Fear of Secession" (1995) as reprinted in Robert Odawi Porter, ed, Sovereignty, Colonialism and the Indigenous Nations: A Reader (Durham, North Carolina: California Academic Press, 2005) 713.

Alfred, Taiaiake. "Sovereignty" in Joanne Barker, ed, Sovereignty Matters: Locations of Contestation and Possibility in Indigenous Struggles for Self-Determinism (Lincoln: University of Nebraska Press, 2005) 33.

---. "Sovereignty: An Inappropriate Concept" (1999) excerpt from Peace, Power, Righteousness: An Indigenous Manifesto (Oxford: Oxford University Press Canada, 1999) as reprinted in Robert Odawi Porter, ed, Sovereignty, Colonialism and the Indigenous Nations: A Reader (Durham, North Carolina: California Academic Press, 2005) 67.

---. Wasáse: Indigenous Pathways of Action and Freedom (North York: Broadview Press, 2005). 
Alfred, Taiaiake \& Corntassel, Jeff. "Being Indigenous: Resurgences against Contemporary Colonialsm” (2005) 40:4 Government and Opposition 597.

Anaya, S. James. Indigenous Peoples in International Law, $2^{\text {nd }}$ ed. (Oxford: Oxford University Press, 2004).

---. "The Capacity of International Law to Advance Ethnic or Nationality Rights Claims" (1990) 75 Iowa L. Rev. 837 as reprinted in Robert Odawi Porter, ed. Sovereignty, Colonialism and the Indigenous Nations: A Reader (North Carolina: California Academic Press, 2005) 681.

---. "Self-determination as a Collective Human Right Under Contemporary International Law" in Pekka Aiko \& Martin Scheinin, eds, Operationalizing the Right of Indigenous Peoples to Self-Determination (Finland: Institute for Human Rights, 2000).

Andrews, Penelope. "Making Room for Critical Race Theory in International Law: Some Practical Pointers" (2000) 45 Vill L Rev 855.

Anghie, Antony. Imperialism, Sovereignty, and the Making of International Law (Cambridge: Cambridge University Press, 2007).

Aristotle. The Politics, revised ed, trans by TA Sinclair, revised and e-presented by Trevor J Saunders (London: Penguin Books, 1992).

Armstrong, Patrick. "Conflict Resolution and British Columbia's Great Bear Rainforest: Lessons Learned 1995-2009" (3 August 2009), online: Coast Forest Conservation Initiative <http://www.coastforestconservationinitiative.com/pdf7/GBR_PDF.pdf>.

Arpi, Claude. "Dams on the Brahmaputra," (1 May 2010), online: Claude Arpi Blogspot <http://claudearpi.blogspot.com/2010/05/dams-on-brahmaputra.html >.

---. "Diverting the Brahmaputra: Declaration of War?" Rediff (23 October 2003), online: Rediff <www.rediff.com///news/2003/oct/27spec.html>.

---. "Himalayan Rivers: Geopolitics and Strategic Perspectives" Indian Defence Review (17 February 2011), online: Indian Defence Review $<$ http://www.indiandefencereview.com/geopolitics/Himalayan-Rivers-Geopoliticsand-Strategic-Perspectives.html>.

Ashley, $\mathrm{K}$ et al. "Restoration of kokanee salmon in Kootenay Lake, a large intermontane lake, by controlled seasonal additions of nutrients" in T Murphy and M Munawar, eds, Aquatic Restoration in Canada (Leiden, Netherlands: Ecovision World Monogaph Series, Backhuys Publishers, 1999) 127. 
Aylward, Carol. Canadian Critical Race Theory (Halifax: Fernwood Publishing 1999).

Bankes, Nigel. "The Columbia Basin and the Columbia River Treaty: Canadian Perspectives in the 1990s" (Working Paper delivered to Northwest Water Law and Policy Project PO95-4, Northwestern School of Law of Lewis and Clark College (1996).

---. "Multiple Actors in Canada-US Relations: Environment: Garrison Dam, Columbia River, The IJC, NGOs" (2004) 30 Can-US LJ 117.

Barker, Adam. "From Adversaries to Allies: Forging Respectful Alliances between Indigenous and Settler Peoples" in Lynn Davis, ed, Alliances: Re/Envisioning Indigenous-Non-Indigenous Relationships (Toronto: University of Toronto Press, 2010) 316 .

Barker, Joanne. "For Whom Sovereignty Matters" in Joanne Barker, ed, Sovereignty Matters: Locations of Contestation and Possibility in Indigenous Struggles for SelfDeterminism (Lincoln: University of Nebraska Press, 2005) 1.

Beach, Heather $\mathrm{L}$ et al. Transboundary freshwater dispute resolution: Theory, practice and annotated references (New York: United Nations University Press, 2000).

Bosselmann, Klaus. "Environmental Governance: A New Approach to Territorial Sovereignty in Robert J Goldstein, ed., Environmental Ethics and Law (Great Britain: The Cromwell Press, 2004) 293.

Bourquain, Knut. Freshwater Access From a Human Rights Perspective: A Challenge to International Water and Human Rights Law (Leiden: Martinus Nijhoff Publishers, 2008).

Brown, Anna \& Odeh, Nancy. "Towards a Global Transboundary Watercourse and Aquifer Agreement (GTWAA) in William R. Moomaw \& Lawrence E. Susskind, eds, Papers on International Environmental Negotiation, Volume 15 Ensuring a Sustainable Future (Boston: MIT-Harvard Public Disputes Program, 2006), online: Program on Negotiation, Harvard Law School $<$ http://www.pon.harvard.edu/shop/papers-on-international-environmentalnegotiation-series/> 1.

Brown, Peter G \& Schmidt, Jeremy J, eds, Water Ethics: Foundational Readings for Students and Professionals (Washington, DC: Island Press, 2010).

Canadian Columbia River Forum. "Canadian Columbia River Forum Memorandum of Understanding", online: Canadian Columbia River Forum, <http://www.ccrf.ca/assets/docs/pdf/MOU_Eng_17.pdf >. 
Canadian Columbia River Inter-Tribal Fisheries Commission (CCRIFC). "Letter from Mr. Fred Fortier, Chairperson of the Canadian Columbia River Inter-Tribal Fisheries Commission (CCRIFC) with respect to the IJC's Order of Approval of December 15, 1941, in the matter of the application of the Government of the United States for approval for the construction and operation of the Grand Coulee dam and reservoir" (23 April 2003), online: International Joint Commission

<www.ijc.org/rel/boards/ccrifc/request_ccrifc-e.htm>.

Canadian Union of Public Employees (CUPE). "UN passes Human Right to Water and Sanitation resolution" CUPE (29 July 2010), online: CUPE <http://cupe.ca/humanrights/un-passes-historic-human-water>.

Center for Columbia River History. "Columbia River", online: Center for Columbia River History [http://www.ccrh.org/river/history.htm\#indigenous].

Central Tibetan Administration. Tibet under Communist China: 50 Years (2001), online: $<$ http://tibet.net/wp-content/uploads/2011/08/TibetUnderCommunistChine50Years.pdf $>$.

Cheyfitz, Eric. "What is a Just Society? Native American Philosophies and the Limits of Capitalism's Imagination: A Brief Manifesto" in Eric Cheyfitz, N. Bruce Duthu, \& Shari M. Huhndorf, eds (Spring 2011) 110:2 S Atl Quart (Special Issue: Sovereignty, Indigeneity, and the Law) 291.

Christie, Gordon. "A Colonial Reading of Recent Jurisprudence: Sparrow, Delgamuukw and Haida Nation" (2005) 23 Windsor YB Access Just 17.

Clark, Regina M. “China's Unlawful Control Over Tibet: The Tibetan People's Entitlement to Self-Determination" in (2001-2002) 12 Ind Int'1 \& Comp L Rev 293.

Cohen, Alice, Malkinson, Leah \& Archer, Jennifer. "The Columbia River Treaty: A Look at Evolving Rights \& Interests in the Negotiation of a Transboundary River Treaty" (2005) [unpublished paper, UBC Faculty of Law].

Columbia River Inter-Tribal Fisheries Commission. "Columbia River Treaty Tribes", online: CRITFC <http://www.critfc.org/text/tribes.html>.

---. "The Importance of Salmon to the Tribes", online: Columbia River Inter-Tribal Fisheries Commission 〈http://www.critfc.org/text/salmcult.html $>$.

Coordinator of Indigenous Organizations of the Amazon Basin (COICA). "Our Organization" online: COICA <http://www.coica.org.ec/ingles/organization/index.html>. 
Corntassel, Jeff J \& Primeau, Tomas Hopkins. "Indigenous 'Sovereignty' and International Law: Revised Strategies for Pursuing Self-Determination" (1995) 17:2 Hum Rts Q as reprinted in (2006) 2 Hawaiian Journal of Law \& Politics 53.

Dalai Lama. "Nobel Peace Prize 1989 The $14^{\text {th }}$ Dalai Lama Acceptance Speech" (1989), online: Nobel Prize, <http://nobelprize.org/peace/laureates/1989/lamaacceptance.html>.

Dasa, Shukavak N. "Non Harming: Ahimsa" A Hindu Primer (2007), online: Sanskrit Religions Institute <http://www.sanskrit.org/www/Hindu\%20Primer/nonharming_ahimsa.html>.

Davidson, Heather C \& Paisley, Richard K. "The Columbia River Basin: Issues \& Driving Forces within the Columbia River Basin with the Potential to Affect Future Transboundary Water Management" (March 2009), online: Canadian Columbia River Forum <http://www.ccrf.ca/assets/docs/pdf/issues-driving-forces-ccrf-final-march2009.pdf>.

Davis, Wade. "Dreams From Endangered Cultures" (Lecture presented to TED, February 2003), online: TED <http://www.ted.com/talks/lang/eng/wade_davis_on_endangered_cultures.html $>$.

---. "The Wayfinders: Why Ancient Wisdom Matters to the Modern World" (Lecture presented to Long Now Foundation, January 2010), online: For a TV Conference Channel

<http://fora.tv/2010/01/13/Wade_Davis_Why_Ancient_Wisdom_Matters_in_the_Mo dern_World $>$.

Dellapenna, Joseph W. "The Customary International Law of Transboundary Fresh Waters" (2001) 1 Int'l J Global Envt'l Issues 264.

Deloria, Jr, Vine. "Self-Determination and the Concept of Sovereignty" in Roxanne Dunbar Ortiz, ed, Economic Development in American Indian Reservations (New Mexico: University of New Mexico, 1979) 22, reprinted in Robert Odawi Porter, ed, Sovereignty, Colonialism and the Indigenous Nations: A Reader (Durham, North Carolina: California Academic Press, 2005) 52.

Dixon, Rebecca Anne. "Global Water Sensitivity of Transboundary Rivers - Levels \& Leakages: The Nile and the Implications for Global Water" (2010) 6 Human Security, online: Atlantic International Studies Organization <http://atlismta.org/onlinejournals/human-security/global-water-sensitivity-of-transboundary-rivers/>.

Dunbar Jr, Christopher. "Critical Race Theory and Indigenous Methodologies" in Norman K. Denzin, Yvonna S Lincoln, \& Linda Tuhiwai Smith, eds, Handbook of Critical and Indigenous Methodologies (Thousand Oaks: SAGE Publications Ltd, 2008) 85 . 
Dutta, Arup Kumar. The Brahmaputra (India: National Book Trust, 2001).

Economist (The). "Unquenchable Thirst: A growing rivalry between India, Pakistan and China over the region's great rivers may be threatening South Asia's peace" The Economist (19 November 2011), online: The Economist <http://www.economist.com/node/21538687>.

Ermine, Willie. "Aboriginal Epistemology" in Marie Ann Battiste \& Jean Barman, eds, First Nations Education in Canada: The Circle Unfolds (Vancouver: UBC Press, 1995) 101.

---. “The Ethical Space of Engagement" in (2007) 6 Indigenous LJ 193.

Fairbanks, Robert A. "Native American Sovereignty and Treaty Rights: Are They Historical Illusions?" (1996) 20 Amer Ind L Rev 141, reprinted in Robert Odawi Porter, ed, Sovereignty, Colonialism and the Indigenous Nations: A Reader (Durham, North Carolina: California Academic Press, 2005) 60.

Flavin, Christopher \& Gardner, Gary. "China, India and the New World Order" in The Worldwatch Institute, ed, State of the World 2006: Special Focus: China \& India (Washington, DC: World Watch Institute, 2006) 3.

Free Tibet. "United Nations Resolutions on Tibet", online: Free Tibet <http://www.freetibet.org/about/united-nations-tibet>.

Gabriel, Ellen (Speaker). "Joint Statement of Grand Council of the Crees (Eeyou Istchee); Inuit Circumpolar Council; Assembly of First Nations: International Alliance of Indigenous and Tribal Peoples of Tropical Forests/Alianza Internacional de los Pueblos Indígenas y Tribales de los Bosques Tropicales; International Indian Treaty Council (IITC); Na Koa Ikaika KaLahui Hawaii; First Nations Summit; Union of British Columbia Indian Chiefs; Network of the Indigenous Peoples-Solomons (NIPS); Federation of Saskatchewan Indian Nations; Treaty 4 Chiefs; Innu Council of Nitassinan; Kus Kura S.C.; Haudenosaunee of Kanehsatà:ke; Kakisiwew Treaty Council; Ochapowace Cree First Nation; Cowessess Cree First Nation; First Peoples Human Rights Coalition; Canadian Friends Service Committee (Quakers); Center for World Indigenous Studies; KAIROS: Canadian Ecumenical Justice Initiatives" (Statement presented to the Expert Mechanism on the Rights of Indigenous Peoples Fourth session, Geneva 11-15 July 2011) [unpublished], online: Canadian Friends Service Committee < http://quakerservice.ca/wp-content/uploads/2011/07/ExpertMECHANISM-Study-re-IPs-Rt-to-Participate-ORAL-Statement-GCC-et-al-July-1211.pdf>.

Gage, Andrew with Banks, Nigel. "Submissions by West Coast Environmental Law to the International Joint Commission: In regard to the application of the Canadian Columbia Inter-Tribal Fisheries Commission Concerning the Grand Coulee Dam" 
(Vancouver: West Coast Environmental Law, October 2005), online, $<$ http://www.wcel.org/resources/publication/submissions-west-coast-environmentallaw-international-joint-commission-regard>.

Gayton, Don. "Ghost River: The Columbia" (2001) 1:2 BC Journal of Ecosystems and Management 1.

Getches, David H. "Indigenous Peoples' Rights to Water Under International Norms" (2005) 16 Colo J Int'l Envtl L \& Pol'y 259.

GEF Global Transboundary International Waters Research Initiative, "Good Practices and Portfolio Learning in GEF Transboundary and Marine Legal and Institutional Frameworks" online: IW Learn 〈http://governance-iwlearn.org/">.

Gilani, Iftikhar. "China's move to divert Tibetan rivers upsets India's plan" The Daily Times (43 November 2003), online: The Daily Times <http://www.dailytimes.com.pk/default.asp?page=story_3-11-2003_pg7_11>.

Gleeson-White, Jane. "Extreme weather and Mother Earth: nature gets legal rights in Bolivia" Overland (17 June 2011), online: Overland $<$ http://overland.org.au/2011/06/extreme-weather-and-mother-earth-nature-gets-legalrights-in-bolivia/>.

Global Security "Indian-China Border Dispute”, online Global Security <http://www.globalsecurity.org/military/world/war/india-china_conflicts.htm>.

Global Water Partnership. "What is IWRM?" online: Global Water Partnership <http://www.gwp.org/en/The-Challenge/What-is-IWRM/>.

---. Strategy 2009-2013 (2009), online: Global Water Partnership <http://www.gwp.org/Global/About\%20GWP/Strategic\%20documents/GWP_Strateg y_2009-2013_final.pdf >

Gourd, Charles A. "Making a Name for Ourselves: The United Nations Draft Statement on the Rights of Indigenous Peoples" (1999) 7 Tulsa J of Comp and Int'l L 121, reprinted in Robert Odawi Porter, ed, Sovereignty, Colonialism and the Indigenous Nations: A Reader (Durham, North Carolina: California Academic Press, 2005) 705.

Groenfeldt, David. "Water Development and Spiritual Values in Western and Indigenous Societies" in R Boelens, M Chiba \& D Nakashima, eds, Water and Indigenous Peoples (Paris: UNESCO, 2006) 108, online: UNESCO $<$ http://portal.unesco.org/science/en/ev.phpURL_ID=4901\&URL_DO=DO_TOPIC\&URL_SECTION=201.html>.

---. "Viewpoint - The Next Nexus? Environmental Ethics, Water Policies and Climate Change" in (2010) 3(3) Water Alternatives 575, online: Water Alternatives 
$<$ http://www.water-

alternatives.org/index.php?option=com_docman\&task=doc_download\&gid=11>.

Green Cross International. National Sovereignty and International Watercourses (The Hague: Ruckstahl SA, 2000).

Grzybowski, Alex, McCaffrey, Stephen C \& Paisley, Richard K. "Beyond International Water Law: Successfully Negotiating Mutual Gains Agreements for International Watercourses" (2010) 22 Global Bus \& Dev't LJ 139.

Hammer, Leonard. "Indigenous People as a Catalyst for Applying the Human Right to Water" (2004) 10 International Journal on Minority and Group Rights 131.

Harden, Blaine. A River Lost: The Life and Death of the Columbia (New York: W.W. Norton \& Company, 1996).

Harjo, Suzan Shown. "In Defense of Native Sovereignty; Indian Advocacy in the American Body Politic" (1998) 15:2 Native Americas reprinted in Robert Odawi Porter, ed, Sovereignty, Colonialism and the Indigenous Nations: A Reader (Durham, North Carolina: California Academic Press, 2005) 659.

Harris, Douglas C. Landing Native Fisheries: Indian Reserves Fishing Rights in British Columbia 1849-1925 (Vancouver: UBC Press, 2008).

Hearns, Glen. "The Columbia River Treaty: A Synopsis of Structure, Content, and Operations" (Prepared for the Canadian Columbia River Forum, September 2008), online: Canadian Columbia River Forum $<\mathrm{http}: / / \mathrm{www} . c c r f . c a / a s s e t s /$ docs/pdf/columbia-river-treaty-synopsis-ccrf-final-sept2008.pdf $>$.

Henderson, James (Sa'ke'j) Youngblood. Indigenous Diplomacy and the Rights of Peoples: Achieving UN Recognition (Saskatoon, Canada: Purich Publishing Ltd, 2008).

Hobbes, Thomas. Leviathan (1651), excerpt reprinted in Elizabeth Knowles, ed, The Oxford Dictionary of Quotations (5 ${ }^{\text {th }}$ ed) (Oxford: Oxford University Press: 1999) 378.

Holslag, Jonathan. "Assessing the Sino-Indian Water Dispute" (2011) 64:2 Journal of International Affairs 19.

Horse, Billy Evans \& Lassiter, Luke E. "A Tribal Chair's Perspective on Inherent Sovereignty" (1997) 10 St Thomas L Rev 79, reprinted in Robert Odawi Porter, ed, Sovereignty, Colonialism and the Indigenous Nations: A Reader (Durham, North Carolina: California Academic Press, 2005) 30. 
Hossain, ANH Akhtar. People's Initiative for Transboundary River Basin Management (Paper presented to the International Conference on Regional Cooperation on Transboundary Rivers: Impact of the Indian River linking Project, Dhaka, 2004).

Hume, Mark. "BC Natives Want Salmon Back in Columbia River: Editorial" The Globe and Mail (2 November 2005).

Hussain, M. "Society in the Brahmaputra Valley" in Vijay P Singh, et al, eds, The Brahmaputra Basin Water Resources (London: Kluwer Academic Publishers, 2004) 336.

Indraguptha, Gihan. "Water as a Human Right: International Dimension" (2011) [unpublished, archived at University of British Columbia Lui Institute of Global Studies].

International Joint Commission. "International Watersheds Initiative: Mandate", online: International Joint Commission <http://www.ijc.org/conseil_board/watershed/en/watershed_mandate_mandat.htm〉.

---. International Watersheds Initiatives: Implementing a New Paradigm for Transboundary Basins - Third Report to Governments on the International Watersheds Initiative (Canada \& United States: International Joint Commission, 2009), online: International Joint Commission $\langle$ http://www.ijc.org/php/publications/pdf/ID1627.pdf $>$.

---. "Response from the IJC to Mr. Fred Fortier on the request from CCRIFC" (31 October 2006), online: International Joint Commission <http://www.ijc.org/en/activities/main_princ.htm\#coulee>

International Water Law Project. "Status of the Watercourse Convention as of 1 August 2011", online: International Water Law Project <http://www.internationalwaterlaw.org/documents/intldocs/watercourse_status.html>

Jones, Alison with Jenkins, Kuni. "Rethinking Collaboration: Working the IndigeneColonizer Hyphen" in Handbook of Critical and Indigenous Methodologies, Norman K Denzin, Yvonna S Lincoln and Linda Tuhiwai Smith (eds) (Sage Publications: London, 2008) 471-486.

Kanping, Hu \& Xiaogang, Yu. "Bridge Over Troubled Waters: the Role of the News Media in Promoting Public Participation in River Basin Management and Environmental Protection in China" in Jennifer L Turner \& Kenji Otsuka, eds, Promoting Sustainable River Basin Governance: Crafting Japan-US Water Partnerships in China (Chiba, Japan: Institute of Developing Economics: 2005) 125. 
Karkkainen, Bradley C. "Transboundary ecosystem governance: Beyond sovereignty?" in Carl Bruch et al, eds, Public Participation in the Governance of International Freshwater Resources (New York: United Nations University Press, 2005).

King III, Frank John. “The Myths Surrounding the Term 'Sovereign'” Indian Country Today (19 January 2000) A5, reprinted in Robert Odawi Porter, ed, Sovereignty, Colonialism and the Indigenous Nations: A Reader (Durham, North Carolina: California Academic Press, 2005) 58-59.

Ktunaxa Nation. "Ktunaxa History Timeline", online: Ktunaxa <http://www.ktunaxa.org/who/timeline.html>.

Lesser, Jonathan A. "Resale of the Columbia River Treat Downstream Power Benefits: One Road From Here to There" (1990) 30 Nat Resources J 610.

Lillooet Tribal Council, ed. "Memorial: To Sir Wilfred Laurier, Premier of the Dominion of Canada From the Chiefs of the Shuswap, Okanagan and Couteau Tribes of British Columbia” V: VIII The St'át'imc Runner (T’ak I sts'úqwas'a/August 2010) 19.

---. "Declaration of the Tahtlan Tribe October 18, 1910" V:X The St'át'imc Runner (Lhwál'tsten/October 2010) 24.

Lil'wat Nation, Mount Currie Band Council. "Introduction and Application for Membership into the International League of United Nations (Fourth World Documentation Project, 1997)" in Robert Odawi Porter, ed, Sovereignty, Colonialism and the Indigenous Nations: A Reader (Durham, North Carolina: California Academic Press, 2005) 677.

Liu, Jie et al. "Water Ethics and Water Resource Management" an Ethics and Climate Change in Asia and the Pacific (ECCAP) Project, Working Group 14 Report (Bangkok: UNESCO, 2011).

Lutz, Ellen. "The Right to Water" in (Sept/Oct 2006) 40:5 Canadian Dimension 43.

Macklem, Patrick. "Indigenous Recognition in International Law: Theoretical Observations" (2008-2009) 30 Mich J of Int'l L 177.

McCaffrey, Stephen C. "A Human Right to Water: Domestic and International Implications” (1992) 5 Geo Int’l Env L R 1.

---. "Introduction: Politics and Sovereignty over Transboundary Groundwater" (Paper presented to Proceedings of the Annual Meeting American Society of International Law Panel Discussion entitled "If Water Respects No Political Boundaries, Does Politics Respect Transboundary Waters?" (2008) 102 American Society of Int'l L Proc. 353, online: JSTOR <http://www.jstor.org/stable/25660314>. 
---. The Law of International Watercourses, $2^{\text {nd }}$ ed (Oxford: Oxford University Press, 2007).

McCue, June. "New Modalities of Sovereignty: An Indigenous Perspective" (2007) 2 Intercultural Human Rights L. Rev 19.

McIntyre, Owen. Environmental Protection of International Watercourses under International Law (Great Britain: MPG Books Ltd, 2007).

Mezey, Naomi. "The Distribution of Wealth, Sovereignty, and Culture through Indian Gaming" (1996) 48 Stan L Rev 711, reprinted in Robert Odawi Porter, ed, Sovereignty, Colonialism and the Indigenous Nations: A Reader (Durham, North Carolina: California Academic Press, 2005) 414.

Mills, Charles W. The Racial Contract, $2^{\text {nd }}$ ed (London: Cornell University Press, 1997).

Mitterand, Danielle. "Tibet Set to Become Next Flashpoint" TibetNet (14 June 2004), online: Students for a Free Tibet <www.studentsforafreetibet.org/article.php?id=271>.

Mobile, AD. "Brahmaputra: Issues in Development" " in Asit K Biswas \& Juha I Uitto, eds, Sustainable development of the Ganges-Brahmaputra-Meghna Basins (New York: United Nations University Press, 2001).

Mock, Gregory. "Transboundary Environmental Governance: The Ebb and Flow of River Basin Organizations" (2003), online: EarthTrends <http://earthtrends.wri.org/text/environmental-governance/feature-46.html>.

Mohawk, John. "On Sovereignty" (1995) 1:3/4 Akwesasne Notes, reprinted in Robert Odawi Porter, ed, Sovereignty, Colonialism and the Indigenous Nations: A Reader (North Carolina: California Academic Press, 2005) 137.

Mutua, Makau W. "Critical Race Theory and International Law: The View of an InsiderOutsider" (2000) 45 Vill L Rev 841, online: Social Science Research Network 〈http://ssrn.com/abstract=1525526>.

Nakayama, Mikiyasu. "China as Basin Country of International Rivers" in Jennifer L Turner \& Kenji Otsuka, eds, Promoting Sustainable River Basin Governance: Crafting Japan-US Water Partnerships in China (Chiba, Japan: Institute of Developing Economics: 2005) 6, online: Institute of Developing Economics, <http://www.ide.go.jp/English/Publish/Spot/28.html>.

Nelson, Dean. "Dalai Lama attacks China's claim of sovereignty over India's Arunachal Pradesh" The Telegraph (09 Nov 2009), online: The Telegraph <http://www.telegraph.co.uk/news/worldnews/asia/india/6531093/Dalai-Lamaattacks-Chinas-claim-of-sovereignty-over-Indias-Arunachal-Pradesh.html $>$. 
Nuxalk Nation. "Statement before the United Nations Working Group in Indigenous Populations, July 31, 1984" (Fourth World Documentation Project, 1997), reprinted in Robert Odawi Porter ed, Sovereignty, Colonialism and the Indigenous Nations: A Reader (Durham, North Carolina: California Academic Press, 2005) 679.

North East Peoples Alliance. "Memorandum to India and China Against Dams on Yarlung Tsangpo", 17 September 2010, online: North East Peoples Alliance, $<$ http://nealliance.net/nepa/memorandum-to-india-and-china-against-dams-onyarlung-tsangpo/>.

Northwest Power Planning and Conservation Council. "Map of the Columbia River Basin", online: Northwest Power Planning and Conservation Council [http://www.nwcouncil.org/library/2004/2004-16/map.htm].

---. The Northwest Power and Conservation Council's Directory of Columbia River Basin Tribes (2007-5), online Northwest Power Planning and Conservation Council at: http://www.nwcouncil.org/library/2007/2007-5.htm> [Directory].

---. "Regional Power System", online: Northwest Power Planning and Conservation Council <http://www.nwcouncil.org/library/2004/2004-16/power.htm>.

Ojha, CSP \& Singh, VP. "Introduction” in Vijay P Singh, Nayan Sharma \& C Shekhar P Ojha, eds, The Brahmaputra Basin Water Resources (London: Kluwer Academic Publishers, 2004).

Oneida Indian Nation of New York. "Sovereignty Statement", online: Oneida Indian Nation <http://oneida-nation.net/sovdoc.html $>$, reprinted in Robert Odawi Porter ed, Sovereignty, Colonialism and the Indigenous Nations: A Reader (Durham, North Carolina: California Academic Press, 2005) 27.

Ortolano, L, Cushing, K \& Contributing Authors. Grand Coulee Dam and the Columbia Basin Project (Case study report prepared as an input to the World Commission on Dams, Cape Town, 2000), online: International Research Center on Environment and Development (CIRED), <http://www.centrecired.fr/IMG/pdf/F9_GranCouleeDam.pdf >.

Osborne, Milton. River at Risk: The Mekong and the Water Politics of China and Southeast Asia (New South Wales: Lowy Institutes for International Policy, 2004).

Paisley, Richard. "Adversaries into Partners: International Water Law and the Equitable Sharing of Downstream Partners" (2002) 3 Melbourne J of Int'l L 280.

Paisley, R \& Hearns, G. "Some Observations from Recent Experiences with the Governance of International Drainage Basins" in AC Corréa and Gabriel Eckstein, eds, Precious, Worthless or Immeasurable: the Value and Ethics of Water, (Lubbock, 
Texas: Texas Tech University, 2006) online: Governance-IWLearn

<http://governance-iwlearn.org/wp-content/uploads/2010/09/Texas-Tech.pdf> 1.

Parlett, Kate. The Individual in the International Legal System: Continuity and Change in International Law (New York: Cambridge University Press, 2011).

Parmar, Pooja. Revisiting the Human Right to Water (LLM Thesis: University of British Columbia, Faculty of Law, 2006) [unpublished].

Pohlner, Huw. "Chinese dam diplomacy: Leadership and geopolitics in continental Asia" in EastAsia Forum (19 August 2010), online: East Asia Forum < http://www.eastasiaforum.org/2010/08/19/chinese-dam-diplomacy-leadership-andgeopolitics-in-continental-asia/>.

Porter, Robert B. "A Proposal to the Hanodaganyas to Decolonize Federal Indian Control Law" (1998) 31 University of Mich J of L Ref 899, reprinted in Robert Odawi Porter ed, Sovereignty, Colonialism and the Indigenous Nations: A Reader (Durham, North Carolina: California Academic Press, 2005) 731.

---. "Strengthening Tribal Sovereignty Through Peacemaking: How the Anglo-American Legal Tradition Destroys Indigenous Societies" (1997) 28 Colum Hum Rts L Rev 235, reprinted in Robert Odawi Porter, ed, Sovereignty, Colonialism and the Indigenous Nations: A Reader (Durham, North Carolina: California Academic Press, 2005) 557.

---. "Strengthening Tribal Sovereignty through Government Reform: What Are the Issues?" (Winter 1997) 7 Kan J L \& Pub Pol'y 72, reprinted in Robert Odawi Porter, ed, Sovereignty, Colonialism and the Indigenous Nations: A Reader (Durham, North Carolina: California Academic Press, 2005) 55 \& 518.

Porter, Robert Odawi. ed, Sovereignty, Colonialism and the Indigenous Nations: A Reader (Durham, North Carolina: California Academic Press, 2005).

Postel, Sandra. "The Missing Piece: A Water Ethic" in Peter G Brown and Jeremy J Schmidt, eds, Water Ethics: Foundational Readings for Students and Professionals (Island Press: Washington, D.C., 2010) 221.

Pradhan, Rajendra, Meinzen-Dick, \& Suseela, Ruth. "Which Rights are Right? Water Rights, Culture, and Underlying Values" in Peter G Brown \& Jeremy J Schmidt, eds, Water Ethics: Foundational Readings for Students and Professionals (Washington, DC: Island Press, 2010) 39.

Regan, Paulette. Unsettling the Settler Within (Vancouver: UBC Press, 2010).

Revenga, Carmen et al. Watersheds of the World: Ecological Value and Vulnerability (Washington, DC: World Resources Institute \& Worldwatch Institute: 1998). 
Richardson, Benjamin J. "Indigenous Peoples, International Law and Sustainability" (2001) 10 RECIEL 1.

---. "The Ties that Bind: Indigenous Peoples and Environmental Governance" in Benjamin J Richardson, Shin Imai \& Kent McNeil, eds, Indigenous Peoples and the Law: Comparative and Critical Perspectives, (Portland: Hart Publishing, 2009) 337.

Richardson, Benjamin J, Imai, Shin \& McNeil, Kent. "Indigenous Peoples and the Law Historical, Comparative and Contextual Issues" in Indigenous Peoples and the Law: Comparative and Critical Perspectives, Benjamin J Richardson, Shin Imai and Kent McNeil, eds (Portland: Hart Publishing, 2009) 3.

Rifkin, Jeremy. The Empathic Civilization: The Race to Global Consciousness in a World in Crisis (New York: Penguin Group, 2009).

Sarma, JN. "An Overview of the Brahmaputra River System" in Vijay P Singh, Nayan Sharma \& C Shekhar P Ojha, eds, The Brahmaputra Basin Water Resources (London: Kluwer Academic Publishers, 2004) 72.

Saskatchewan Watershed Authority. "Celebrating and Conserving Water", online: Saskatchewan Watershed Authority <http://www.swa.ca/WaterConservation/default.asp?type=CelebratingWater >

Shelton, Dinah. "Water Rights of Indigenous Peoples and Local Communities" (Paper presented to the University of Geneva, Geneva, Switzerland Conference "Freshwater and International Law: the Multiple Challenges" 7-9 July 2011, June 2011) [unpublished].

Sievers, Eric W. "Transboundary Jurisdiction and Watercourse Law: China, Kazakhstan and the Irtysh" (2002) 37 Tex Int'l L J 1.

Sinixt Nation "Keeping the Lakes Way", online: Sinixt Nation $<$ http://sinixt.kics.bc.ca/history.html>.

Sinvhal Amita \& Prakash, Vipul. "Seismo-Tectonics and Earthquake Design Parameters" in Vijay P Singh, Nayan Sharma \& C Shekhar P. Ojha, eds, The Brahmaputra Basin Water Resources (London: Kluwer Academic Publishers, 2004) 578.

Smith, Linda Tuhiwai. Decolonizing Methodologies: Research and Indigenous Peoples (New Zealand: University of Otago Press, 2002).

Stoeckel, Katherine Jane. Economics and the Equitable Utilization of Transboundary Freshwater (LLM Thesis, University of British Columbia, Faculty of Law, 2004, [unpublished]. 
Swainson, Neil. "The Columbia River Treaty - Where Do We Go From Here" (1986) 26 Nat Resources J 252.

Talukdar, BK. "Ecology" in Vijay P Singh, Nayan Sharma \& C Shekhar P Ojha, eds, The Brahmaputra Basin Water Resources (London: Kluwer Academic Publishers, 2004) 351.

Tarcena, Connie. "Implementing the Declaration: A State Representative Perspective" in Jackie Hartley, Paul Joffe, and Jennifer Preston, eds, Realizing the UN Declaration on the Rights of Indigenous Peoples: Triumph, Hope, and Action, (Saskatoon: Purich Publishing Ltd., 2010) 60.

Thorson, Erica J. "Sharing Himalayan Glacial Meltwater: The Role of Territorial Sovereignty" (2009) 19 Duke J Comp \& Int'l L 487, online: Duke University School of Law $\langle$ http://www.law.duke.edu/shell/cite.pl?19+Duke+J.+Comp.+\&+Int'l+L.+487+pdf $>$.

Tsering, Tashi. China's Water Politics: In Whose Interest?, (MA Thesis in Political Science, Portland State University, 2005) [unpublished].

---. "Damming Tibet's Yarlung Tsangpo-Brahmaputra and other South Asian rivers" Tibetan Plateau (24 May 2010), online: Tibetan Plateau Blogspot <http://tibetanplateau.blogspot.com/2010/05/damming-tibets-yarlung-tsangpo.html $>$.

Turner, Jennifer L \& Zhi, Lü. "Building a Green Civil Society in China" in The Worldwatch Institute, ed, State of the World 2006: Special Focus: China \& India (Washington, D.C.: Worldwatch Institute, 2006) 3.

Umpleby, Sandra Lynne. Crossing Bridges: The Educational Leadership of First Nations Women (Phd Thesis, Education, University of Victoria, 2007).

Upreti, BC. Politics of Himalayan River Waters: An Analysis of River Water Issues of Nepal, India and Bangladesh (New Dehli: Nirala Publications, 1993).

Walkem, Ardith. Bringing Water to the Land, (LLM Thesis: UBC, 2005).

Watts, Jonathan. "Chinese engineers propose world's biggest hydro-electric project in Tibet" The Guardian (24 May 2010), online: The Guardian $<$ http://www.guardian.co.uk/environment/2010/may/24/chinese-hydroengineerspropose-tibet-dam>.

Weiji, Zhongguo Shui. China's Water Crisis trans by Nancy Yang Liu \& Lawrence R. Sullivan (Nowalk: EastBridge, 2004).

Wilson, JW. People in the Way: The Human Aspects of the Columbia River Project (Toronto: University of Toronto Press, 1973). 
Wolf, Aaron T. "Indigenous approaches to water conflict negotiations and implications for international waters" (2000) 5 International Negotiation: A Journal of Theory and Practice 2.

Wouters, Patricia \& Tremblay, Hugo. Book Review of Freshwater Access from a Human Rights Perspective by Knut Bourquain (2009) 10:2 Melbourne J Int'1 L 705.

Wouters, Patricia et al. "The New Development of Water Law in China" (2004) 7 Univ of Denver Water Law Rev 243.

Yahua, Wang. "River Governance Structure in China: A Study of Water Quantity/Quality Management Regimes" in Jennifer L Turner and Kenji Otsuka (eds) Promoting Sustainable River Basin Governance: Crafting Japan-US Water Partnerships in China (Chiba, Japan: Institute of Developing Economics: 2005) 23.

Ying, Rong: "Remembering a War: The 1962 India-China Conflict", Rediff (December 2002) online: Rediff < http://www.rediff.com/news/2002/dec/20chin.htm>. 


\section{Appendix}

\section{Appendix A: Indigenous Water Declarations \& Recommendations}

Declaration of the People's World Water Movement (New Dehli, India, January 2004), online: Indigenous Environment Network <http://www.ienearth.org/docs/WaterDeclaration_WorldsWaterMovementNewDelhiI ndiaJanuary2004IndigenousSection.pdf>

Garma International Indigenous Water Declaration (Australia, 2008) online: UN University Traditional Knowledge Initiative <http://www.unutki.org/downloads/File/Water/Garma\%20International\%20Indigeno us\%20Water\%20Declaration_LMMar09.pdf>.

Indigenous Peoples Kyoto Water Declaration ( $3^{\text {rd }}$ World Water Forum, Kyoto Japan) 2003, online UNESCO $<$ http://portal.unesco.org/science/en/files/3872/10917799361IP_Water_Declaration_E nglish.doc/IP\%2BWater\%2BDeclaration\%2BEnglish.doc $>$.

Protection of Water, Intervention to the Seventh Session of the United Nations Permanent Forum on Indigenous Issues 2008 Submitted by the Seventh Generation Fund for Indian Development Agenda Item 3: Special theme: Climate change, biocultural diversity and livelihoods: the stewardship role of Indigenous peoples and new challenges, online: Indigenous Environment Network $<$ http://www.ienearth.org/docs/WaterPFII72008Item3InterventiononProtectionofWat ersubmittedbySGF.html>.

Report of the Indigenous Peoples' Presentation on the Topic of: "Spirituality and Sustainability - Water, the Common Element", Presented to the Council for a Parliament of the World's Religions' 2004 Goldin Institute for International Partnership and Peace Annual Forum November 6-12, 2004, Taipei, Taiwan, online at: Indigenous Environmental Network <http://www.ienearth.org/docs/WaterTaiwanReport.html>.

TLATOKAN ATLAHUAK DECLARATION, Declaration of the Indigenous Peoples Parallel Forum of the 4th World Water Forum, Mexico City, Mexico, March 17-18, 2006, online: <http://www.treff-raumespaciotime.com/en/articles/TLATOKANATLAHUAKDECLARATION.htm>.

Weledeh Declaration (Tu Cho International Indigenous Water Rights Conference, Yellowknife) 21-23 June 2006, online: Kairos Canada <http://www.kairoscanada.org/fileadmin/fe/files/PDF/EcoJustice/Water/Report_Tu_C ho_water_conference_2007.pdf $>$. 
WATER IS LIFE: PROTECT WATER NOW! Indigenous Declaration on Water, July 8th, 2001 Musqueam Territory, British Columbia, Canada, online: Blue Planet Project $\langle\mathrm{http} / / /$ blueplanetproject.net/documents/Indigenous_Declaration.pdf $>$.

WATER IS LIFE: PROTECT WATER NOW! Indigenous Declaration on Water, Endorsed at the 12th annual Indigenous Environmental Network Protecting Mother Earth Conference, Penticton Indian Band Okanagan Nation Territories, British Columbia, Canada, reprinted in "On the endorsement and adoption of the Indigenous Declaration on Water From the Indigenous Environmental Network's 12th Annual Protecting Mother Earth Conference", (2-5 August 2001), online: Indigenous Environmental Network < http://www.ienearth.org/docs/WaterandIndigenousPeoplesIndigenousEnvironmental NetworkStatementOntheendorsementandadoptionoftheIndigenousDeclarationonWate r.html>. 